\title{
Meroterpenoids produced by fungi
}

\author{
Regina Geris $^{* a}$ and Thomas J. Simpson ${ }^{b}$ \\ Received 22nd May 2009 \\ First published as an Advance Article on the web 19th June 2009 \\ DOI: $10.1039 / b 820413 f$
}

Covering: 1968 up to August 2008

This review deals with the isolation and structure elucidation of meroterpenoids (natural products of mixed biosynthetic origin which are partially derived from terpenoids) from higher and lower fungi, and discusses biosynthetic studies and biological activities as appropriate. It describes 333 fungal meroterpenoids and cites 195 references.

\section{Introduction \\ 2 Meroterpenoid classification \\ 3 Meroterpenoids containing triketide-terpenoid moieties \\ 4 Meroterpenoids containing tetraketide-terpenoid moieties \\ 4.1 Derived from orsellinic acid \\ 4.2 Derived from 3-methylorsellinic acid \\ 4.3 Derived from 5-methylorsellinic acid \\ 4.4 Derived from 3,5-dimethylorsellinic acid \\ 4.5 Derived from other tetraketides \\ 5 Meroterpenoids containing other polyketide-terpenoid moieties \\ 6 Meroterpenoids containing non-polyketide-terpenoid moieties \\ 7 Miscellaneous meroterpenoids \\ 8 Conclusions \\ 9 Acknowledgements \\ 10 References}

\section{Introduction}

The term meroterpenoid was first applied by Cornforth, in 1968 , to describe natural products of mixed biosynthetic origin which are partially derived from terpenoids. ${ }^{1}$ The prefix mero- (from Greek merus) means 'part, partial or fragment'2 and, therefore, a number of secondary metabolites can be described as meroterpenoids. ${ }^{3}$ Cytokinins, e.g., $\mathbf{1}$ and $\mathbf{2},{ }^{4}$ phenylpropanoid compounds containing isoprenoid side chains, e.g., 3-6, ${ }^{5,6}$ and alkaloids such as anticancer drugs vincristine $\mathbf{7}$ and vinblastine $\mathbf{8}^{\mathbf{3}}$ are also included in this class of compounds.

These natural products are most often isolated from fungi and marine organisms, but higher plants can also produce meroterpenoids, such as tetrahydrocannabinol $9^{7}$ and bakuchiol 10. ${ }^{8}$ In addition to their wide occurrence, meroterpenoids display a huge range of structural diversity, with structures varying from simple compounds like montadial A 11, comprising a prenyl unit

${ }^{a}$ Instituto de Química, Universidade Federal da Bahia, 40170-290, BA, Brasil. E-mail: rmgeris@ufba.br; Fax: +55-71-3237 4117; Tel: +55-713283-6817

${ }^{b}$ School of Chemistry, University of Bristol, BS8 1TS, UK linked to a phenolic derivative, ${ }^{9}$ to the more complex meroterpenoids arising from highly functionalised carbon chains. Moreover, they display important biological activities, which will be discussed in this review.

Although their occurrence is general, we will limit this review to meroterpenoids that have been isolated from fungi. Due to the proliferation of trivial names that are attached to these compounds, the literature (via Chemical Abstracts, Web of Science, Scirus, and PubMed databases) was searched for meroterpenoids using the following search terms: meroterpene(s), meroterpenoid(s), mixed-terpenoid(s), polyketide-terpenoid(s), alpha-pyrone(s) and triprenyl-phenols.

\section{Meroterpenoid classification}

Although diverse in structure, meroterpenoids can be grouped into two major classes based on their biosynthetic origins: polyketide-terpenoids and non-polyketide-terpenoids.

Polyketides (PKs) are a large class of natural products synthesized by bacteria, fungi, and plants through the successive condensation of simple carboxylic acids. ${ }^{10}$ These metabolites are related by their common biosynthetic origins derived from highly functionalised carbon chains whose assemblies are controlled by multifunctional enzyme complexes, the polyketide synthases (PKSs), which catalyse repeated sequences of decarboxylative condensation reactions between simple acyl thioesters and malonate, as shown in Fig. 1. ${ }^{11-15}$

Therefore, polyketide-terpenoid meroterpenoids are classified here by grouping the compounds first according to the number of acyl units which have contributed to the polyketide chain and then according to the type of cyclization which the (hypothetical) precursor has undergone.

The non-polyketide group of meroterpenoids is formed from compounds which arise from the shikimate route, represented by protocathecuic acid derivatives, quinones, dehydroquinic acid or closely related subunit linked to a terpenoid moiety by at least one $\mathrm{C}-\mathrm{C}$ bond.

\section{Meroterpenoids containing triketide-terpenoid moieties}

Naturally occurring bioactive spiro-diterpenoids (+)-breviones A-E 12-16 have been obtained from extracts of semi-solid 
<smiles>C/C(=C\CNc1cccc2[nH]cnc12)CO</smiles><smiles>CC(CO)CCNc1cccc2[nH]cnc12</smiles><smiles></smiles>

3<smiles>CC(C)=CCOc1ccc(/C=C/CO)cc1</smiles><smiles>CC(C)=CCC/C(C)=C/COc1ccc(/C=C/CO)cc1</smiles>

5<smiles>CC1(C)C=Cc2cc(/C=C/CO)ccc2O1</smiles><smiles>CCCCCCCCCCc1cc(O)c2c(c1)OC(C)(C)[C@@H]1CCC(C)=CC21</smiles>

9<smiles>C=C[C@](C)(/C=C/c1ccc(O)cc1)CCC=C(C)C</smiles>

10<smiles>CC(=O)/C=C/Cc1cc(C(C)=O)cc(O)c1O</smiles>

11

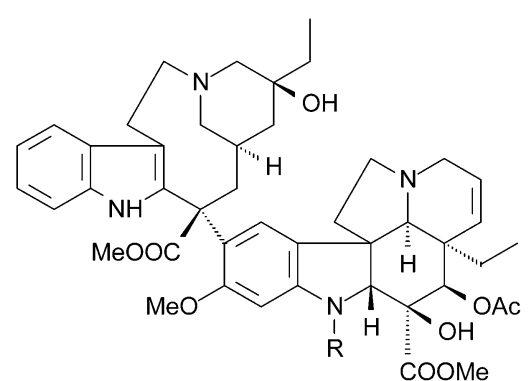

7: $\mathrm{R}=\mathrm{CHO}$

8: $\mathrm{R}=\mathrm{Me}$ fermented Penicillium brevicompactum Dierckx. ${ }^{16,17}$ The structures display the breviane spiro-diterpenoid skeleton and were elucidated by chemical transformations and by homo- and heteronuclear 2D-NMR spectroscopic data. These compounds inhibit wheat coleoptile growth, therefore suggesting their use as new agrochemicals. ${ }^{16,17}$

Their biosynthesis may proceed through combined polyketide and terpenoid pathways as shown in Scheme $1 .{ }^{17}$ Thus, addition of geranylgeranyl to the pyrone $\mathbf{1 7}$ derived from three molecules of acetyl CoA and one methyl from methionine, followed by cyclization, would give the breviane skeleton 18. Oxidation at $\mathrm{C}$ 3 and C-14 and cyclization to produce the spirocycle would lead to brevione B 13. Dehydrogenation of 13 to give 12, and subsequent expansion of the A ring of $\mathbf{1 2}$ and dehydrogenation would give brevione $\mathrm{C}$ 14. A radical mechanism via a cyclopropane which would account for this is indicated in Scheme 1. Oxidation of C-15 in 14 may generate brevione D 15, and further oxidation at $\mathrm{C}-1$ and $\mathrm{C}-17$ would result in tetrahydrofuran formation

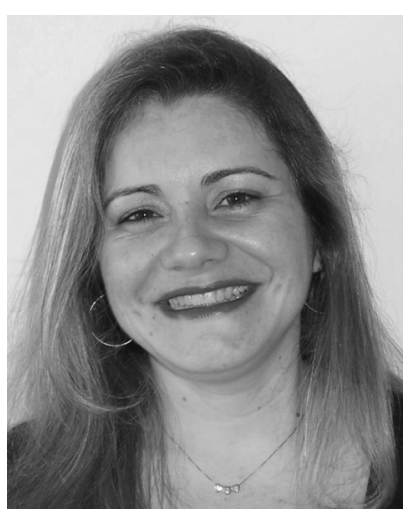

Regina Geris
Regina Geris received her M.Sc. and Ph.D. degrees from the Universidade Federal de São Carlos, Brazil, where she studied the interaction between plants and endophytic fungi and their relationship to secondary metabolites, under supervision of Dr. Edson Rodrigues Filho. During her Ph.D. she carried out a traineeship in the School of Chemistry, Bristol, UK, where she developed a research project entitled "Isolation of Fungal Meroterpenoid Genes”, under the supervision of Professor Tom Simpson. In 2003 she was a postdoctoral research fellow with Dr. Edson Rodrigues Filho at the Universidade Federal de São Carlos, Brazil. She is currently working at the Instituto de Química at Universidade Federal da Bahia in Salvador, Brazil, and her research interests are focused on the chemistry of natural products from microorganisms.

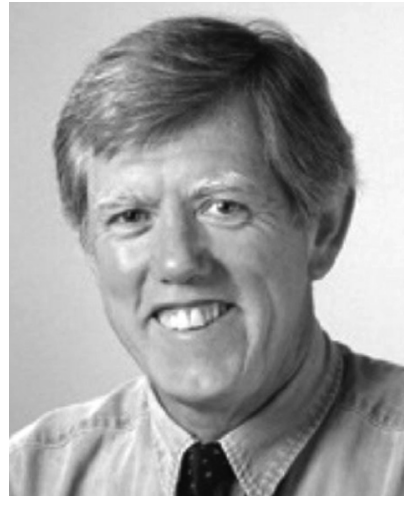

Tom Simpson
Tom Simpson graduated from the University of Edinburgh in 1969, and gained his Ph.D. from the University of Bristol in 1973 working with Jake MacMillan. After postdoctoral work in the University of Liverpool with Stan Holker and the Australian National University with Arthur Birch, he was appointed to a Lectureship in Chemistry at the University of Edinburgh in 1978. In 1988 he moved to Professorships in Organic Chemistry in the University of Leicester in 1988, and Bristol University in 1990, where he holds the Alfred Capper Pass Chair of Chemistry. His research, which covers all aspects of the chemistry and biosynthesis of microbial natural products, has led to ca. 180 papers. He has received a number of awards including the Royal Society of Chemistry Corday Morgan Medal (1984) the Simonsen (2002), Tilden (2001) and Hugo Muller (2004) Lectureships, and the Microbial Chemistry Medal of the Kitatsato Institution in 2005. He was elected Fellow of the Royal Society in 2001 and Fellow of the Royal Society of Edinburgh in 2006. He was a founder member and past Chairman of the NPR Editorial Board. 


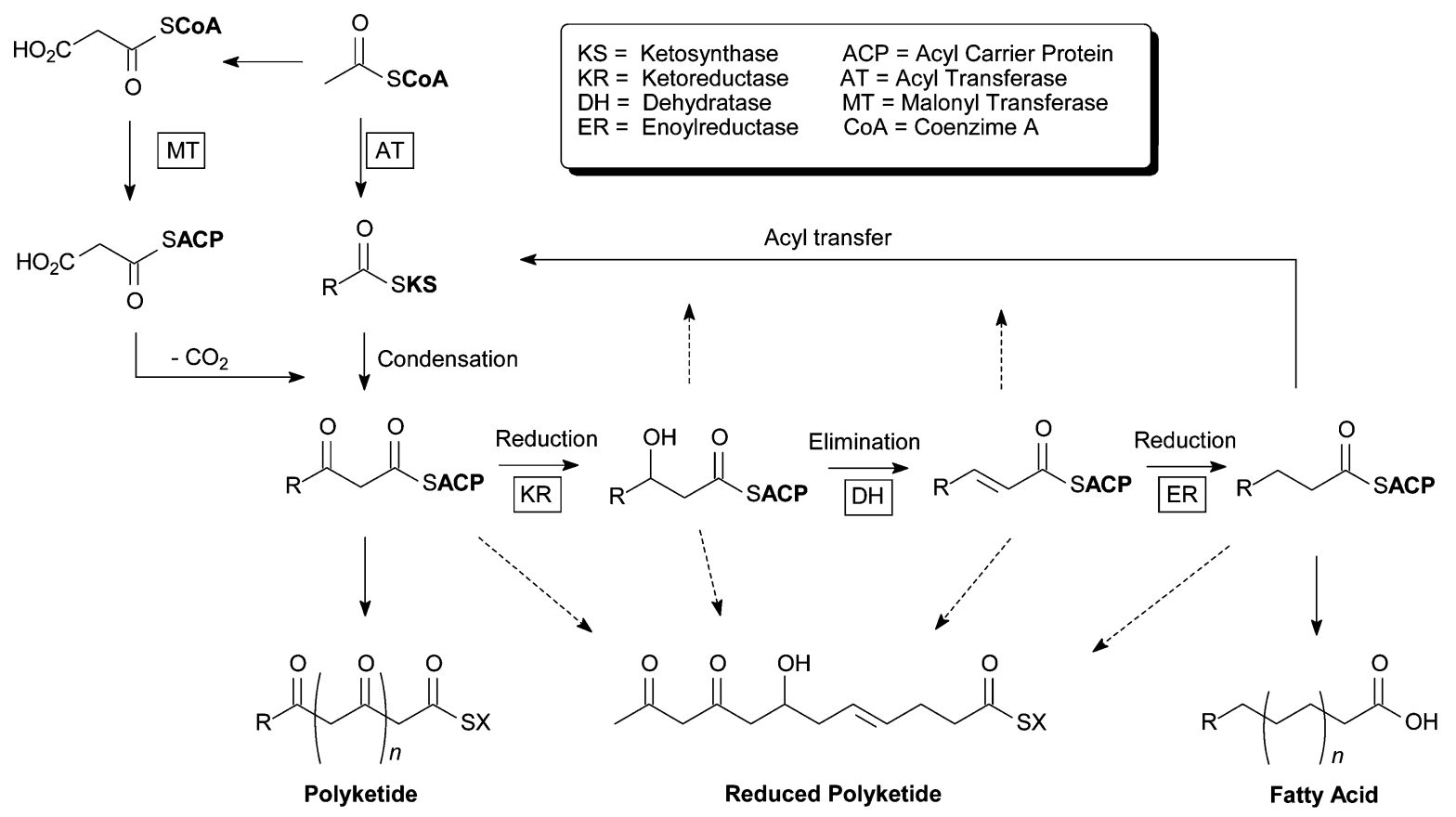

Fig. 1 The assembly of fatty acids, polyketides and reduced polyketides.

between rings $\mathrm{A}$ and $\mathrm{B}$ and conversion of $\mathrm{C}-17$ to an aldehyde. Opening of the spiran and lactone rings would allow formation of the hemiketal ring, decarboxylation and formation of the seven-membered spirocycle, and finally acetylation to brevione E 16.

Pycnophorin 19, a metabolite with antimicrobial activity, was isolated from the full-grown mycelia-bearing pycnidia of $\mathrm{Mac}$ rophoma kuwatsukai (a causal agent of ring rot of apple), and was shown to be a diterpene $\alpha$-pyrone (with a trisubstituted 4-hydroxy- $\alpha$-pyrone ring) by spectroscopic studies. ${ }^{18}$

One of the differences between the biosynthesis of polyketides and fatty acids is the possibility of having a wide variety of chainstarting units (such as acetate, propionate, benzoate, cinnamate and amino-acids). ${ }^{11}$ Thus, the following compounds in this review can be classified as triketides.

Ling and co-workers ${ }^{19,20}$ have reported the isolation of three tremorgenic mycotoxins, territrems A 20, B 21 and C 22, from rice cultures of Aspergillus terreus. These compounds induced whole body tremor when injected into rats or mice. In addition, compound 21 might potentiate the release of acetylcholine. ${ }^{21}$ To investigate the relationship between the structures and inhibition of acetylcholinesterase activity, $\mathbf{2 1}$ was incubated with rat liver microsomes, producing four metabolites. MB2 [4- $\alpha$-(hydroxymethyl)- $4 \alpha$-demethylterritrem B] $\mathbf{2 3}$ was the major metabolite, which arose from hydroxylation of the pro- $S$-methyl group at C-4 of $21 .^{21,22}$

In the course of screening for selective inhibitors of acethylcholinesterase, arisugacins A $\mathbf{2 4}$ and B $\mathbf{2 5}$ were obtained from the culture broth of Penicillium sp. Fo-4259 together with the structurally related compounds territrems B 21 and C 22. ${ }^{23,24}$ Their structures were elucidated by extensive spectroscopic studies, including a combination of 1-D and 2-D NMR techniques. ${ }^{25}$ Treatment of this microorganism with UV-light yielded a mutant strain which was a high producer of arisugacins. ${ }^{26}$ Further isolation studies led to the discovery of arisugacins $\mathrm{C}-\mathrm{H} \mathrm{26-31}{ }^{26}$ The relative stereochemistries of $\mathbf{2 4}$, 25 and 29 have been elucidated by differential NOE experiments $^{27}$ and modified Mosher method. ${ }^{28}$ Arisugacins are proposed to be biosynthesized from a sesquiterpene, a diketide and a benzoate-derived triketide from their structural similarity to pyripyropenes. ${ }^{25,27}$

Terreulactones A-D 32-35, isolated from a solid fermented culture of Aspergillus terreus Fb000501, also showed potent inhibitory activities against acetylcholinesterase ${ }^{29-31}$ and appear to be biosynthetically related to arisugacins. ${ }^{30,31}$ Moreover, $\mathbf{3 2}$ is so far the only sesquiterpene meroterpenoid to have a fused lactone skeleton in its sesquiterpene moiety. ${ }^{29}$ Further investigation on the polar metabolites of this microorganism resulted in the isolation of a seven-membered lactone containing meroterpenoid named isoterreulactone $\mathrm{A} \mathbf{3 6},{ }^{32}$ which appears to arise from 34 by a Baeyer-Villiger reaction.

Four pyripyropenes A-D 37-40 were isolated from the fermentation broth of Aspergillus fumigatus FO-1289 by a combination of solvent extraction, silica gel plus ODS column chromatography and HPLC. ${ }^{33}$ These compounds showed very potent ACAT (Acyl-CoA:cholesterol acyltransferase) inhibitory activity, ${ }^{34}$ and their structures were determined mainly by spectroscopic studies including various NMR measurements. ${ }^{35}$ In addition, the relative and absolute stereochemistry of $\mathbf{3 7}$ has been elucidated by NOE experiments, X-ray crystallographic analysis and Mosher's NMR method. ${ }^{36}$

A mutant high producer of pyripyropenes, A. fumigatus FO1289-2501 (treated with $N$-methyl- $N^{\prime}$-nitro- $N$-nitrosoguanidine), when cultured in a production medium supplying $0.002 \%$ nicotinic acid, produced fourteen additional pyripyropenes E-R 4154, which were isolated from the ethyl acetate extracts of the fermentation broth. ${ }^{37,38}$ 


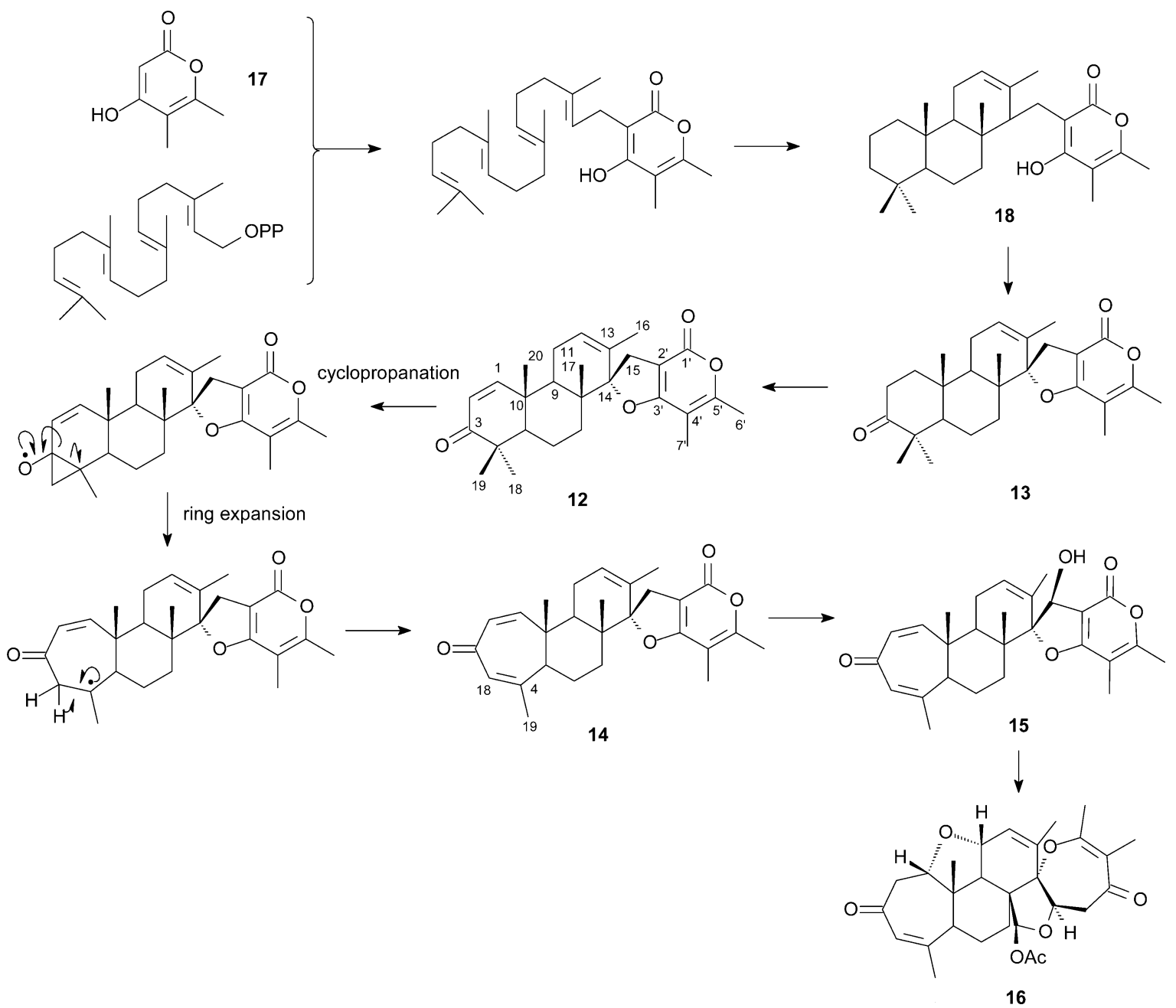

Scheme 1 A postulated biosynthetic origin for the breviane skeleton (adapted from Macias et al. ${ }^{17}$ ).<smiles>CC(C)=CCCC1C(=O)CCC2CC(C)(CCc3c(O)c(C)c(C)oc3=O)CCC21</smiles>

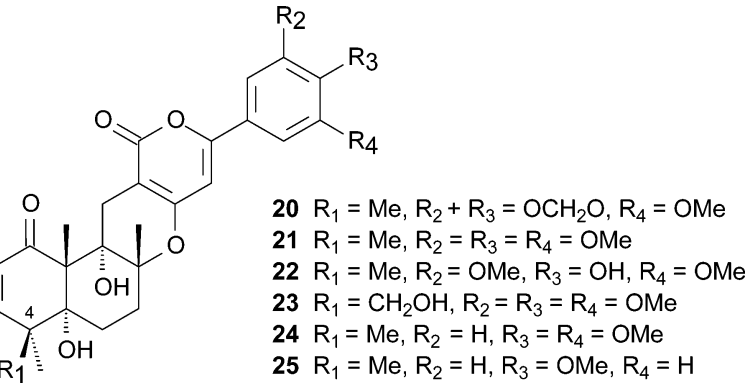

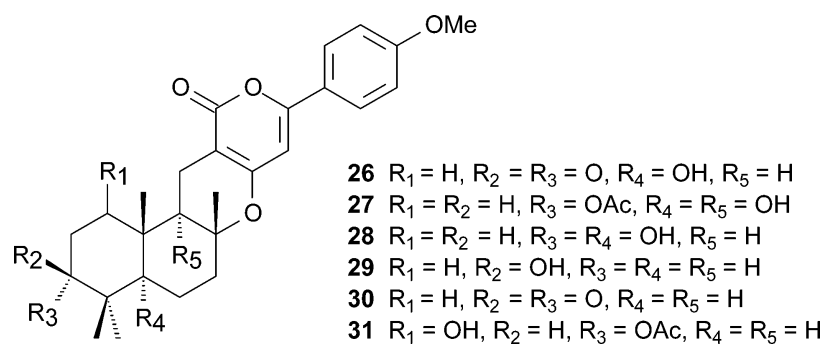

Pyripyropenes have a common skeleton consisting of a polyoxygenated sesquiterpene, $\alpha$-pyrone and pyridine moieties. Three of the four hydroxyl residues on the sesquiterpene moiety are acylated by acetyl and propionyl groups to form the various pyripyropenes. ${ }^{39}$ In order to establish the biosynthetic origin of 37, sodium $\left[1-{ }^{13} \mathrm{C}\right],\left[2-{ }^{13} \mathrm{C}\right]$ and $\left[1,2-{ }^{13} \mathrm{C} 2\right]$ acetates, DL- $\left[2-{ }^{13} \mathrm{C}\right]$ mevalonolactone and [carboxy- ${ }^{14} \mathrm{C}$ ]nicotinic acid were fed to cultures of A. fumigatus FO-1289-2501 and their enriched products were analyzed by NMR. The likely biosynthesis is shown in Scheme 2. The acyl primer nicotinic acid $\mathbf{5 5}$ is 


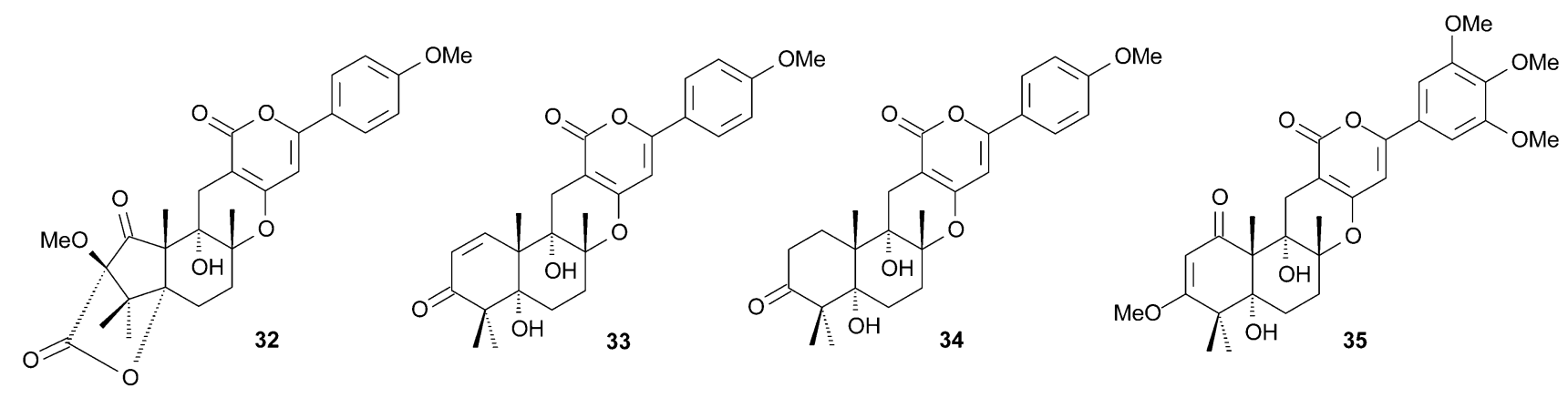<smiles>COc1ccc(-c2cc3c(c(=O)o2)CC2(C)C(C)(C)CCC(O)(O3)C2(C)O)cc1</smiles>

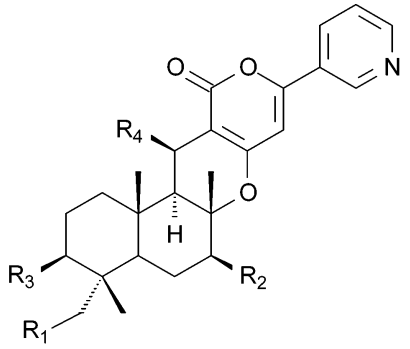

$37 \mathrm{R}_{1}=\mathrm{R}_{2}=\mathrm{R}_{3}=\mathrm{OAc}, \mathrm{R}_{4}=\mathrm{OH}$

$38 \mathrm{R}_{1}=\mathrm{OCOEt}, \mathrm{R}_{2}=\mathrm{R}_{3}=\mathrm{OAc}, \mathrm{R}_{4}=\mathrm{OH}$

$39 \mathrm{R}_{1}=\mathrm{OAc}, \mathrm{R}_{2}=\mathrm{OCOEt}, \mathrm{R}_{3}=\mathrm{OAc}, \mathrm{R}_{4}=\mathrm{OH}$

$40 \mathrm{R}_{1}=\mathrm{R}_{2}=\mathrm{OAC}, \mathrm{R}_{3}=\mathrm{OCOEt}, \mathrm{R}_{4}=\mathrm{OH}$

$41 R_{1}=R_{2}=H, R_{3}=O A c, R_{4}=H$

$42 R_{1}=R_{2}=H, R_{3}=$ OCOEt, $R_{4}=H$

$43 \mathrm{R}_{1}=\mathrm{R}_{2}=\mathrm{H}, \mathrm{R}_{3}=\mathrm{OAc}, \mathrm{R}_{4}=\mathrm{OH}$

$44 R_{1}=R_{2}=H, R_{3}=$ OCOEt, $R_{4}=O H$

$45 \mathrm{R}_{1}=\mathrm{R}_{2}=\mathrm{R}_{3}=\mathrm{OCOEt}, \mathrm{R}_{4}=\mathrm{OH}$

$46 R_{1}=O A C, R_{2}=R_{3}=O C O E t, R_{4}=O H$

$47 \mathrm{R}_{1}=$ OCOEt, $\mathrm{R}_{2}=\mathrm{OAC}, \mathrm{R}_{3}=\mathrm{OCOEt}, \mathrm{R}_{4}=\mathrm{OH}$

$48 R_{1}=R_{2}=O C O E t, R_{3}=O A c, R_{4}=O H$

$49 \mathrm{R}_{1}=\mathrm{OAc}, \mathrm{R}_{2}=\mathrm{OCOEt}, \mathrm{R}_{3}=\mathrm{OAc}, \mathrm{R}_{4}=\mathrm{H}$

$50 R_{1}=$ OCOEt, $R_{2}=H, R_{3}=$ OCOEt, $R_{4}=O H$

$51 \mathrm{R}_{1}=\mathrm{OAc}, \mathrm{R}_{2}=\mathrm{H}, \mathrm{R}_{3}=\mathrm{OAc}, \mathrm{R}_{4}=\mathrm{H}$

$52 R_{1}=$ OCOEt, $R_{2}=H, R_{3}=O A C, R_{4}=H$

$53 \mathrm{R}_{1}=$ OCOEt, $\mathrm{R}_{2}=\mathrm{H}, \mathrm{R}_{3}=\mathrm{OAC}, \mathrm{R}_{4}=\mathrm{OH}$

$54 R_{1}=$ OAc, $R_{2}=H, R_{3}=$ OCOEt, $R_{4}=H$

sequentially condensed with two acetates to form 5-(3-pyridyl)3,5-dioxopentanoic acid 56, which is converted to a pyridino- $\alpha$ pyrone 57. Then, an all-trans farnesyl pyrophosphate produced from three mevalonates and the putative pyridino- $\alpha$-pyrone $\mathbf{5 7}$ are condensed and cyclized to form the core skeleton 58. Finally, three acetyl residues from acetate are introduced into the skeleton to yield $37 .{ }^{39}$

Another meroterpenoid that appears to derive from a pathway involving nicotinic acid (ring A), polyketide (ring B), and diterpenoid (rings C, D, E, and F) moieties is oxalicine A 59, isolated from Penicillium oxalicum. ${ }^{40}$ The stereostructure of this hexacyclic alkaloidal meroterpene was established from spectroscopic data and single-crystal X-ray analysis. ${ }^{40}$ Later, oxalicine B 60 was obtained from the same fungus. ${ }^{41}$ From rice cultures of $P$. decaturense and $P$. thiersii three insecticidal compounds were obtained (described as alkaloids in the literature): 15-deoxyoxalicine B 61, decaturin A 62 and B $63 .{ }^{41}$ Further work on extracts of $P$. thiersii revealed three additional related compounds, 15-deoxyoxalicine A 64, decaturin C 65 and D 66, in addition to the known decaturins. Compounds 66 showed potent insecticidal activity against Spodoptera frugiperda. ${ }^{42}$ The oxalicines and decaturins are biosynthetically related to pyripyropenes but with the incorporation of a diterpenoid unit rather than the sesquiterpenoid component found in the pyripyropenes. ${ }^{42}$

\section{Meroterpenoids containing tetraketide-terpenoid moieties}

Tetraketide-terpenoid-derived compounds constitute the largest class of meroterpenoids. They can be conveniently subdivided according to the number of carbons introduced to the tetraketide precursor. $^{43}$

Orsellinic acid 67 is the parent compound derived by cyclization of the polyketide precursor, while 6-methylsalicylic acid $\mathbf{6 8}$ is formed by loss of one of the oxygen atoms (by reduction) from the tetraketide precursor. ${ }^{43} 3$-Methylorsellinic acid 69, 5-methylorsellinic acid 70, and 3,5-dimethylorsellinic acid $\mathbf{7 1}$ are formed by addition of methyl groups derived from $S$-adenosylmethionine onto the basic tetraketide precursor. The timing and mechanism of these modifications are uncertain but do occur prior to release of the aromatic product from the polyketide synthase.

\subsection{Derived from orsellinic acid}

Cultures of several isolates of Stachybotrys spp. have produced a series of phenylspirodrimanes, many of them endowed with important biological activities such as 


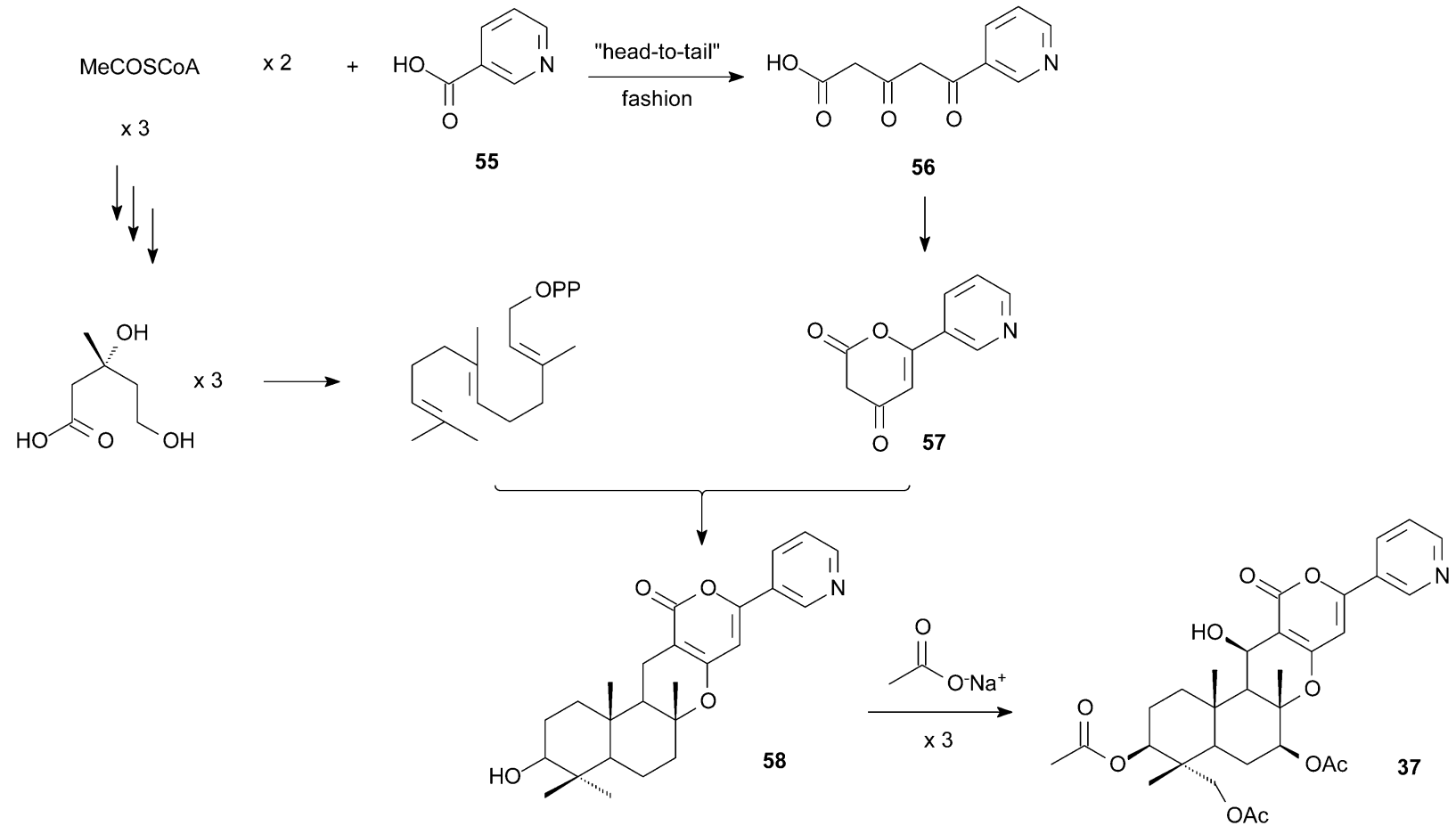

Scheme 2 Proposed biosynthetic pathway of pyripyropene A 37.

immunosuppressant ${ }^{44}$ and protease inhibitor activities. ${ }^{45-47}$ These include the spirobenzofuranaldehyde $\mathbf{7 2},{ }^{48}$ the corresponding benzyl alcohols $\mathbf{7 3} \mathbf{4 4}^{-46}$ and $\mathbf{7 4},{ }^{45}$ and the dialdehydes $\mathbf{7 5}^{44,45}$ and $76^{44,47}$

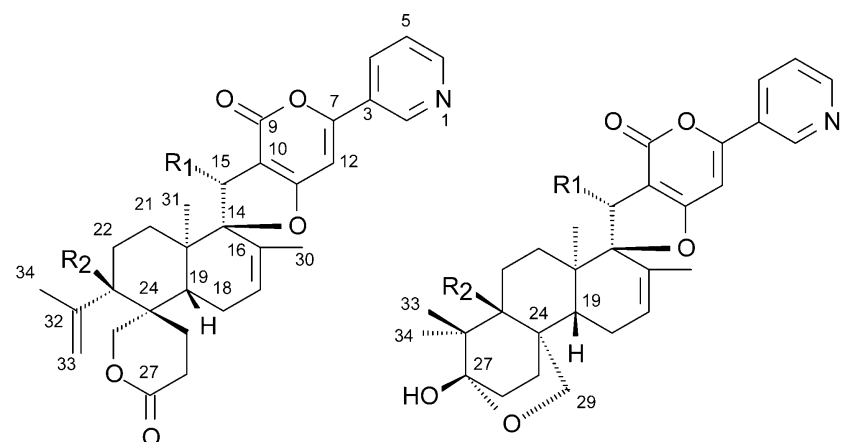

$59 \mathrm{R}_{1}=\mathrm{OH}, \mathrm{R}_{2}=\mathrm{H}$

$60 \mathrm{R}_{1}=\mathrm{OH}, \mathrm{R}_{2}=\mathrm{OH}$

$61 \mathrm{R}_{1}=\mathrm{H}, \mathrm{R}_{2}=\mathrm{OH}$

$62 R_{1}=R_{2}=H$
$63 \mathrm{R}_{1}=\mathrm{H}, \mathrm{R}_{2}=\mathrm{OH}$
$64 \mathrm{R}_{1}=\mathrm{OH}, \mathrm{R}_{2}=\mathrm{H}$

$65 \mathrm{R}_{1}=\mathrm{R}_{2}=\mathrm{H}$

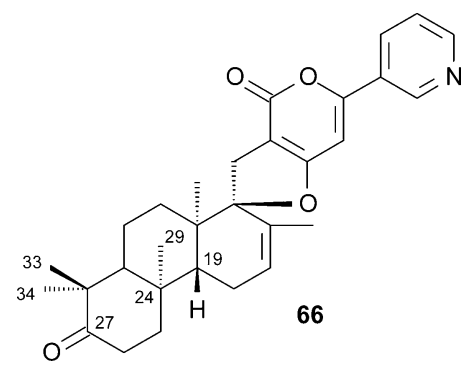

These compounds are relatively unstable and often undergo conversion to the stachybotrylactams and stachybotrylactones, ${ }^{49}$ producing the following metabolites: stachybotrylactone (or

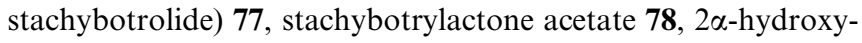
stachybotrylactone $\mathbf{7 9}, 2 \alpha$-hydroxystachybotrylactone acetate 80, stachybotrylactam 81, stachybotrylactam acetate 82, $2 \alpha-$ acetoxystachybotrylactam acetate $\mathbf{8 3}$ and stachybotramide (or stachybotryn) 84. These compounds exhibit anticomplement immunosuppressant activities. ${ }^{44,46}$ The additional compounds $\mathbf{8 5}, \mathbf{8 6}$ and $\mathbf{9 0}$, also named as spirocyclic drimanes, are endothelin<smiles>Cc1cc(O)cc(O)c1C(=O)O</smiles>

67<smiles>Cc1cccc(O)c1C(=O)O</smiles>

68<smiles>Cc1cc(O)c(C)c(O)c1C(=O)O</smiles>

69<smiles>Cc1c(O)cc(O)c(C(=O)O)c1C</smiles>

70<smiles>Cc1c(C)c(O)c(C(=O)O)c(C)c1O</smiles>

71

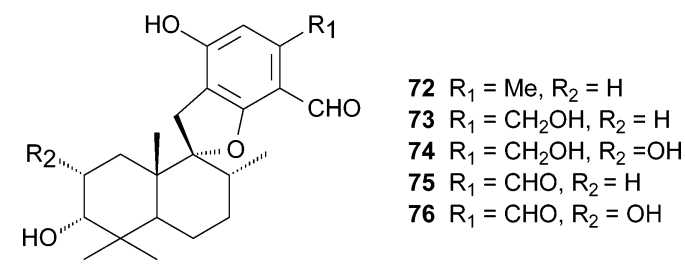


receptor antagonists, ${ }^{46}$ while $\mathbf{8 7}, \mathbf{8 8}$, and $\mathbf{8 9}$ act as cholesterol esterase inhibitors. ${ }^{50}$

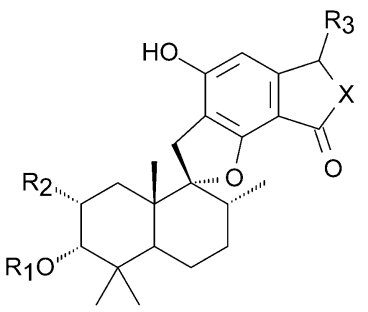

$77 X=O, R_{1}=R_{2}=R_{3}=H$

$78 X=O, R_{1}=A c, R_{2}=R_{3}=H$

$79 X=O, R_{1}=H, R_{2}=O H, R_{3}=H$

$80 X=O, R_{1}=A c, R_{2}=O A c, R_{3}=H$

$81 X=N H, R_{1}=R_{2}=R_{3}=H$

$82 X=N H, R_{1}=A c, R_{2}=R_{3}=H$

$83 X=N H, R_{1}=A c, R_{2}=O A c, R_{3}=H$

$84 X=\mathrm{NCH}_{2} \mathrm{CH}_{2} \mathrm{OH}, \mathrm{R}_{1}=\mathrm{R}_{2}=\mathrm{R}_{3}=\mathrm{H}$

$85 X=\mathrm{N}\left(\mathrm{CH}_{2}\right)_{4} \mathrm{COOH}, \mathrm{R}_{1}=\mathrm{R}_{2}=\mathrm{R}_{3}=\mathrm{H}$

$86 X=\mathrm{NCH}(\mathrm{COOH})\left(\mathrm{CH}_{2}\right)_{2} \mathrm{COOH}, \mathrm{R}_{1}=\mathrm{R}_{2}=\mathrm{R}_{3}=\mathrm{H}$

$87 X=\mathrm{NH}, \mathrm{R}_{1}=\mathrm{H}, \mathrm{R}_{2}=\mathrm{OH}, \mathrm{R}_{3}=\mathrm{OMe}$

$88 X=\mathrm{NH}\left(\mathrm{CH}_{2}\right)_{3} \mathrm{COOCH}_{3}, \mathrm{R}_{1}=\mathrm{H}, \mathrm{R}_{2}=\mathrm{OH}, \mathrm{R}_{3}=\mathrm{H}$

$89 X=\mathrm{NH}\left(\mathrm{CH}_{2}\right)_{4} \mathrm{COOCH}_{3}, \mathrm{R}_{1}=\mathrm{R}_{2}=\mathrm{H}, \mathrm{R}_{3}=\mathrm{H}$

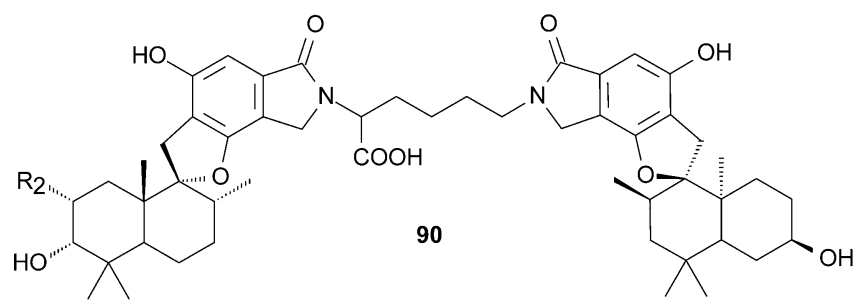

An RAS farnesyl-protein transferse (FPTase) activity bioassay guided the isolation of four tetra- and pentacyclic aromatic sesquiterpenoids, the kampanols A-C 91-93, from Stachybotrys kampalensis Hansf. ${ }^{51}$

Stachyflin 94 and acetylstachyflin 95 have been isolated by solid-state fermentation of Stachybotrys sp. RF7260. ${ }^{52,53}$ They contain a pentacyclic moiety including a $c i s$-fused decalin, and showed antiviral activity against influenza A virus in vitro with an<smiles>CC(=O)OC1CC[C@@]2(C)[C@H](CC[C@@H]3Oc4c(c(O)cc5c4COC5=O)C[C@@H]32)C1(C)C</smiles>

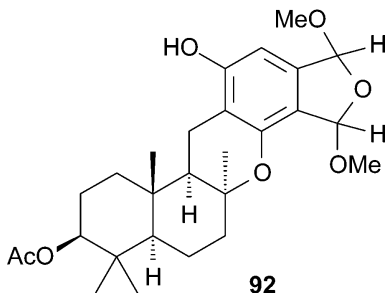<smiles>CC(=O)OC1CC[C@@]2(C)[C@H](CC[C@H]3Oc4c(C=O)c(C=O)cc(O)c4C[C@@H]32)C1(C)C</smiles>

$\mathrm{IC}_{50}$ value of $0.003 \mu \mathrm{M}$ for 94. Further studies resulted in isolation of the related compounds $\mathbf{9 6}-101 .^{54}$

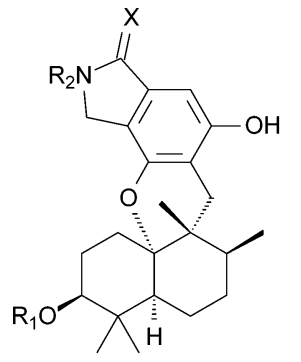

$$
94 X=O, R_{1}=R_{2}=H
$$

$95 X=O, R_{1}=A c, R_{2}=H$

$96 \mathrm{X}=\mathrm{O}, \mathrm{R}_{1}=\mathrm{Ac}, \mathrm{R}_{2}=\left(\mathrm{CH}_{2}\right)_{4} \mathrm{CH}\left(\mathrm{NH}_{2}\right) \mathrm{COOH}$

$97 \mathrm{X}=\mathrm{O}, \mathrm{R}_{1}=\mathrm{Ac}, \mathrm{R}_{2}=\mathrm{CH}(\mathrm{COOH}) \mathrm{CH}\left(\mathrm{CH}_{3}\right)_{2}$

$98 \mathrm{X}=\mathrm{NH}_{2}{ }^{+} \mathrm{Cl}^{-}, \mathrm{R}_{1}=\mathrm{R}_{2}=\mathrm{H}$

$99 \mathrm{X}=\mathrm{NH}_{2}{ }^{+} \mathrm{Cl}^{-}, \mathrm{R}_{1}=\mathrm{Ac}, \mathrm{R}_{2}=\mathrm{H}$

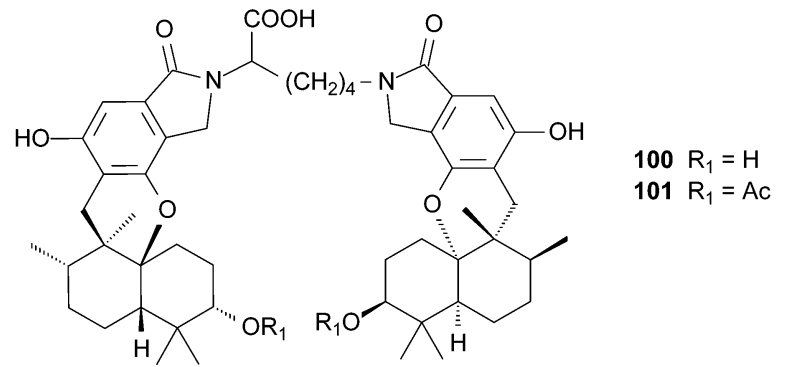

Memnoniella echinata is closely related to Stachybotrys chartarum, and produces the compounds $\mathbf{7 2}$ and $\mathbf{7 4}$ together with spirobenzofurandialcohol $\mathbf{1 0 2} .^{55}$ These exhibited inhibitory activity against myoinositol monophosphatase. In addition, four metabolites have been isolated from a rice culture of $M$. echinata by solvent extraction and radial silica chromatography. The structures were identified as memnobotrin A 103, and B 104, and the linear isoprenoid derivatives memnoconol 105 and memnoconone $106 .{ }^{56}$

Another Stachybotrys sp. also produced secondary metabolites having a pyrano-isoindolinone ring system, the stachybotrins A 107, B 108 and C 109, as well as a hydroxy-farnesyl phenol, parvisporin $110 .{ }^{57,58}$

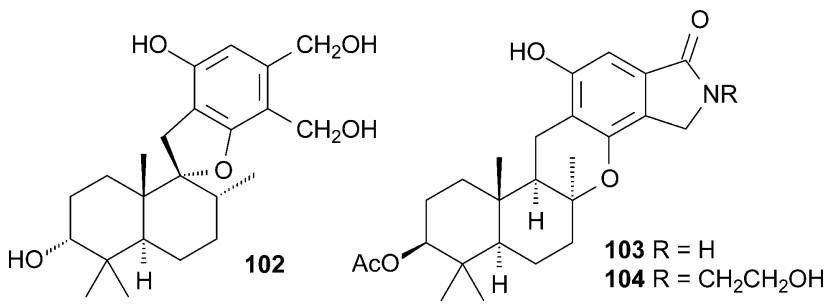<smiles>C/C(=C\Cc1c(O)cc2c(c1O)COC2=O)CC/C=C(\C)CCC(O)C(C)(C)O</smiles><smiles>C/C(=C\Cc1c(O)cc2c(c1O)COC2=O)CC/C=C(\C)CCC(=O)C(C)C</smiles> 
<smiles>[R2]CC(=CCC[C@]1(C)Oc2c(c(O)cc3c2CN([R1])C3=O)C[C@@H]1O)CCC=C(C)C</smiles>

$107 \mathrm{R}_{1}=\mathrm{H}, \mathrm{R}_{2}=\mathrm{OH}$

$108 R_{1}=H, R_{2}=H$

$109 \mathrm{R}^{1}=\left(\mathrm{CH}_{2}\right) \mathrm{PhOH}, \mathrm{R}_{2}=\mathrm{H}$<smiles>CC(=CCc1c(O)cc(CO)c(C=O)c1O)CCC=C(C)CCCC(C)(C)O</smiles>

110
Other meroterpenoids, having an acyclic terpenoid backbone, are hericenone A 111 and B 112, cytotoxic phenols isolated from the edible mushroom Hericium erinaceum. ${ }^{59}$ Hericenones $\mathrm{C}-\mathrm{H}$ 113-118 were also obtained. They showed stimulation activity for the synthesis of nerve growth factor. ${ }^{60,61}$ Two additional aromatic compounds, erinacerin A 119 and B 120, were obtained in a further investigation of $H$. erinaceum. ${ }^{62}$

Five triprenylphenol metabolites, designated staplabin 121, SMTP-3-6 122-125, have been isolated from cultures of Stachybotrys microspora. ${ }^{63,64}$ A combination of spectroscopic analyses showed that 122-125 are staplabin analogs, containing respectively a serine, a phenylalanine, a leucine or a tryptophan moiety in place of the $N$-carboxybutyl portion of staplabin. These compounds showed effects on plasminogen activation and fibrinolysis. ${ }^{63,64}$ Two staplabin analogs with a pseudosymmetric structure were also obtained, SMTP-7 126 and SMTP-8 127. ${ }^{65}$ The former consisted of two identical staplabin core structures<smiles>[X]C1=C(O)c2c(cc(OC)c(C/C=C(\C)CC(=O)C=C(C)C)c2O)C1</smiles>

$111 X=0$ $112 X=\mathrm{NCH}_{2} \mathrm{CH}_{2} \mathrm{C}_{6} \mathrm{H}_{5}$<smiles>[R]Cc1cc(OC)c(C/C=C(\C)CC(=O)C=C(C)C)c(O)c1C=O</smiles>

$113 \mathrm{R}=\mathrm{CO}\left(\mathrm{CH}_{2}\right)_{14} \mathrm{CH}_{3}$ $114 \mathrm{R}=\mathrm{CO}\left(\mathrm{CH}_{2}\right)_{16} \mathrm{CH}_{3}$ $115 \mathrm{R}=\mathrm{CO}\left(\mathrm{CH}_{2}\right)_{7} \mathrm{CH}=\mathrm{CH}_{2} \mathrm{CH}=\mathrm{CH}\left(\mathrm{CH}_{2}\right)_{4} \mathrm{CH}_{3}$<smiles>[R]OCc1cc(OC)c2c(c1C=O)OC(C)(CC(=O)C=C(C)C)CC2</smiles>

$116 \mathrm{R}=\mathrm{CO}\left(\mathrm{CH}_{2}\right)_{14} \mathrm{CH}_{3}$

$117 \mathrm{R}=\mathrm{CO}\left(\mathrm{CH}_{2}\right)_{16} \mathrm{CH}_{3}$

$118 \mathrm{R}=\mathrm{CO}\left(\mathrm{CH}_{2}\right)_{7} \mathrm{CH}=\mathrm{CH}_{2} \mathrm{CH}=\mathrm{CH}\left(\mathrm{CH}_{2}\right)_{4} \mathrm{CH}_{3}$<smiles>COc1cc2c(c3c1CCC(C)(CC(=O)C=C(C)C)O3)CN(CCc1ccccc1)C2=O</smiles>

119<smiles>COc1cc2c(c(O)c1C/C=C(\C)CC(O)C=C(C)C)COC2=O</smiles>

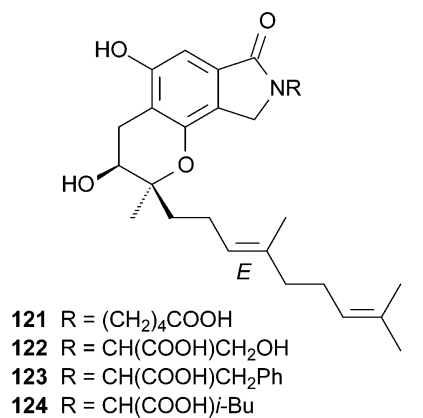<smiles>CC(C)=CCC/C(C)=C/CC[C@]1(C)Oc2c(cc(O)c3c2CN(C(Cc2c[nH]c4ccccc24)C(=O)O)C3=O)CC1O</smiles>

125<smiles>CC(C)=CCC/C(C)=C/CCC1(C)Cc2c(c(O)cc3c2CN(CC2c4c(O)cc5c(c4CN2C(C)C(=O)O)OC(C)(CC/C=C(\C)CCC=C(C)C)[C@@H](O)C5)C3=O)CC1O</smiles><smiles></smiles>

$128 \mathrm{R}=\mathrm{CH}(R-\mathrm{COOH}) \mathrm{CH}_{2} \mathrm{Ph}$

$129 \mathrm{R}=\mathrm{CH}(\mathrm{R}-\mathrm{COOH}) i-\mathrm{Bu}$<smiles>CC(C)=CCC/C(C)=C/CC[C@]1(C)Oc2c(c(O)cc3c2CN(C(Cc2c[nH]c4ccccc24)C(=O)O)C3=O)CC1O</smiles>

130

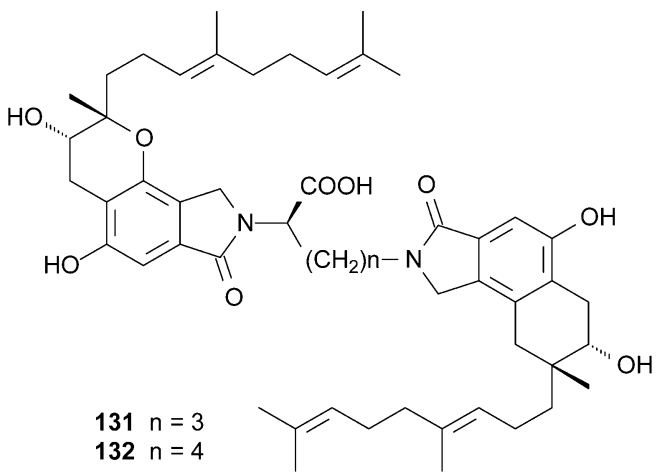


and ornithine, which bridges the two partial structures while in the latter the bridging unit was lysine. These compounds exhibited plasminogen activation and fibrinolyses levels higher than those of staplabins. ${ }^{65}$

Five other SMTPs belonging to the D-series (from precursor Damino-acid analogs) were also isolated from the cultures of S. microspora. They were designated as SMTP-4D to -8D 128132 and showed a 10-fold enhancement of urokinase-catalyzed plasminogen activity. ${ }^{66}$

The antibiotics hongoquercins A 133 and B 134 were isolated from the extracts of an unidentified fungus. They are related to a class of compounds commonly found in brown algae and dictyoceratid sponges, and exhibited moderate activity against Gram-positive bacteria. ${ }^{67}$

\subsection{Derived from 3-methylorsellinic acid}

Xenovulene $\mathrm{A}^{\circledR} \mathbf{1 3 5}$ was isolated from submerged cultures of the fungus Acremonium strictum during a screening programme for inhibition of benzodiazepine binding to the $\mathrm{GABA}_{\mathrm{A}}$ receptor. ${ }^{68}$

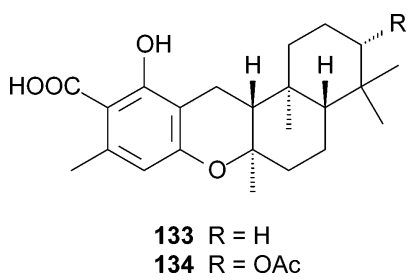

It contains an unusual polyketide-derived bicyclic cyclopentenone moiety linked by a furan ring to an 11-membered ring derived from the sesquiterpenoid humulene. A number of minor co-metabolites of $\mathbf{1 3 5}$ have been isolated in which the cyclopentenone moiety is replaced by trioxygenated benzene 136, or highly oxygenated tropolone rings 137 and $138 .{ }^{69}$

Incorporation studies with ${ }^{13} \mathrm{C}$-labelled acetates and methionine in A. strictum indicate that the cyclopentenone moiety in $\mathbf{1 3 5}$ is formed by a unique pathway in which a $\mathrm{C}$-methylated phenolic precursor 69 would be converted by standard biosynthetic modifications to the lactol 139 (Scheme 3). This would react with the C6-C7 double bond of humulene $\mathbf{1 4 0}$ to give the key tetracyclic intermediate 141, which undergoes ring expansion to a tropolone followed by two successive ring contractions, resulting in incorporation of the $\mathrm{C}$-methyl carbon into the fivemembered ring. ${ }^{69}$

However, a PKS gene has recently been isolated from xenovulene producing cultures of $A$. strictum. ${ }^{70}$ Heterologous expression of the gene in Aspergillus oryzae resulted in the production of 3-methylorcinaldehyde 142, suggesting that it is the actual precursor to the xenovulenes rather than the acid 69.

The very similar fungal metabolites pycnidione $143^{71}$ and eupenifeldin $\mathbf{1 4 4}^{\mathbf{7 2}}$ were isolated from cultures of Phoma sp and Eupenicillium brefeldianum, respectively. They contain a similar fusion of a tropolone to humulene. The former is a bistropolone stromelysin inhibitor while the latter showed cytotoxic activity against the HCT-116 cell line as well as in vivo antitumor activity in the P388 leukemia model.<smiles>Cc1cc(O)c(C)c(O)c1C(=O)O</smiles>

69<smiles>O=Cc1c(O)cc2c(c1O)C(O)OC2</smiles>

139

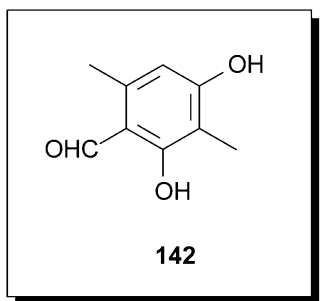<smiles>CCC(C)=CCCC(C)=CCC(C)C</smiles>

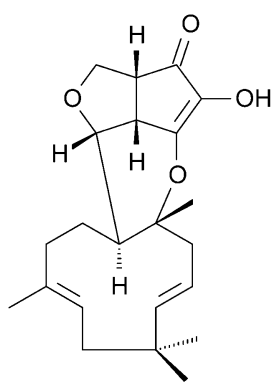

135

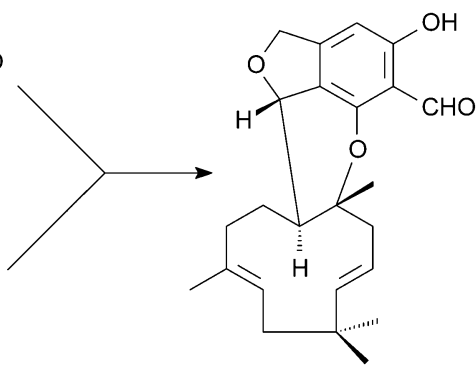

141

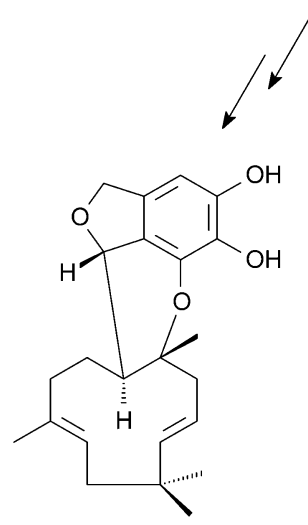

136

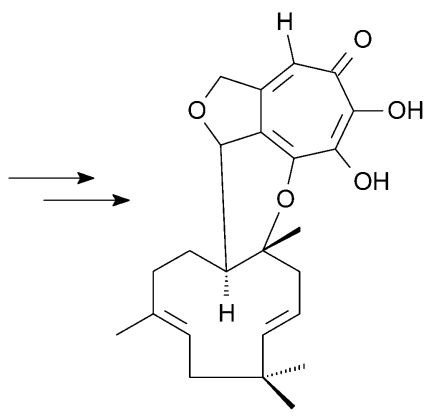

137
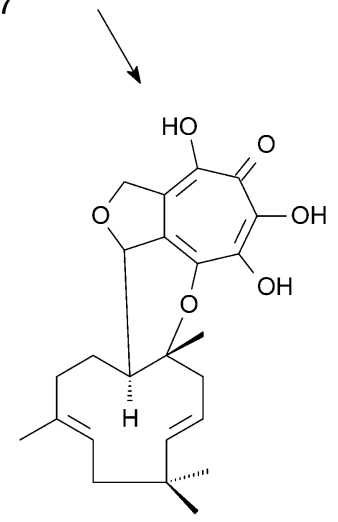

138

Scheme 3 The proposed pathway to xenovulene metabolites 135-138 (adapted from Raggatt et al. ${ }^{69}$ and Bailey et al. ${ }^{70}$ ). 
Screening for inducers of erythropoietin gene expression led to the isolation of the epolones A 145 and B 146 as well as 143 from the cultures of the fungus OS-F69284. ${ }^{73}$ In several independent experiments, these compounds reproducibly induced erythropoietin gene expression in epo-3-cells. The $\mathrm{TIR}_{5 \mathrm{x}}$ (concentration resulting in 5-fold greater induction) of them was in the range of 1.0-1.6 $\mu \mathrm{M}$. In addition, noreupenifeldin 147, a monotropolone derivative of 144, was isolated from an unidentified ascomycete by bioassay-guided fractionation for new anthelmintics. ${ }^{74}$

\subsection{Derived from 5-methylorsellinic acid}

Several species of Penicillium, including P. brevicompactum, ${ }^{75,76}$ P. stoloniferum, P. scabrum, P. nagemi, P. szaferi, P. patris-mei, $P$. griscobrunneum and $P$. viridicatum were reported to produce mycophenolic acid (MPA) 148, in agreement with Muth and Nash. ${ }^{77}$ Due to diverse biological properties such as antiviral, antifungal, antibacterial, antitumor, immunosuppressive, and anti-psoriasis activities, ${ }^{77}$ several efforts were made to elucidate its biosynthesis, and labelling studies have implicated several phenolic intermediates derived from a tetraketide in the biosynthesis of 148, leading to isolation of demethylmycophenolic acid (DMPA) 149, 6-farnesyl-5,7-dihydroxy-4-methylphthalide $\mathbf{1 5 0}$ and 151. ${ }^{77-79}$

MPA has been demonstrated to consist of an acetatederived aromatic nucleus, the 5-methylorsellinic acid $\mathbf{7 0}$ and a sesquiterpenoid side-chain. According to Colombo et al. ${ }^{79}$ 6-farnesyl-5,7-dihydroxy-4-methylphthalide $\mathbf{1 5 0}$ is converted into MPA 148 by (as shown in Scheme 4), at least two pathways: direct oxidation of the central olefinic double bond and a two-stage removal of the terminal and central units.
Their experiments indicated that these two pathways are equally important and the following sequence was proposed: a) epoxidation to give $\mathbf{1 5 2}$, b) rearrangement of the epoxide to a ketone $\mathbf{1 5 3}, \mathrm{c}$ ) hydroxylation to an $\alpha$-hydroxy-ketone $\mathbf{1 5 4}, \mathrm{d}$ ) and finally Woodward reaction with $\mathrm{C}-\mathrm{C}$ bond cleavage and formation of the acid 149. The last step involves the transfer of a methyl-group from $S$-adenosyl-L-methionine (SAM) to DMPA $149 .{ }^{77}$

Investigations of toxigenic cultures of Aspergillus ustus (Bainier) Thom. \& Church (strain MRC 1163) resulted in the isolation of 12 biosynthetically related metabolites, austalides AL 155-166. ${ }^{80-82}$

Biosynthetic studies on the austalides indicate that these meroterpenoids are also derived from phthalide $150{ }^{83,84}$ A plausible mechanism for the formation of austalides consistent with the known relative stereochemistry was presented by de Jesus et ll. $^{83}$ and revised by Dillen et al. ${ }^{84}$ Scheme 5 shows some steps of the proposed metabolic route. In order to generate the cis-fused chroman ring of the austalides, the involvement of a C-11 carbocation 167 was proposed, with subsequent stereoespecific attack of the C-7 phenolic oxygen atom at C-11 (to the $\mathrm{Si}$-face) to produce the chroman ring of the austalides $168 .^{83}$ Further oxidative processes such as hydroxylations and Baeyer-Villiger oxidation lead to the other related austalides. ${ }^{83}$

\subsection{Derived from 3,5-dimethylorsellinic acid}

The first member of this group, andibenin 169, was described in 1976 as a metabolite of Aspergillus variecolor. ${ }^{85}$ A mixed polyketide-terpenoid biosynthesis rather than the originally

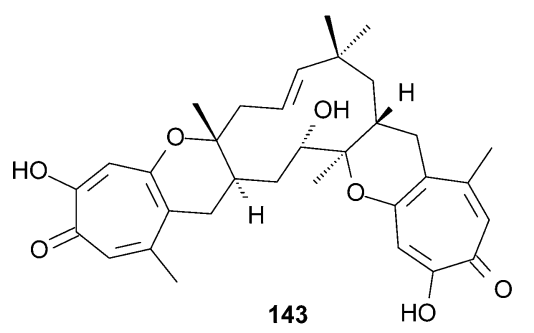<smiles>CCC=CC(C)(C)C[C@@H]1Cc2c(C)cc(=O)c(O)cc2O[C@@H]1C(O)C[C@H]1Cc2c(C)cc(=O)c(O)cc2C1(C)C</smiles><smiles>Cc1cc(=O)c(O)cc2c1C[C@@H](CC(C)(C)C)[C@@H](C(O)CC1Cc3c(C)cc(O)cc3OC1(C)C)O2</smiles><smiles></smiles><smiles>Cc1cc(=O)c(O)cc2c1C[C@@H](CC(C)(C)C)[C@@H](C(O)C[C@H]1Cc3c(C)cc(O)cc3OC1(C)C)O2</smiles>

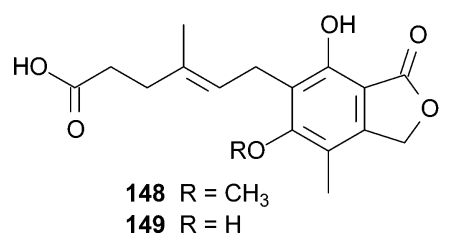<smiles>CC(C)=CCC/C(C)=C/CC/C(C)=C/Cc1c(O)c(C)c2c(c1O)C(=O)OC2</smiles><smiles>C/C(=C\Cc1c(O)c(C)c2c(c1O)C(=O)CO2)CC/C=C(\C)CCC(=O)O</smiles>

$149 \mathrm{R}=\mathrm{H}$ 


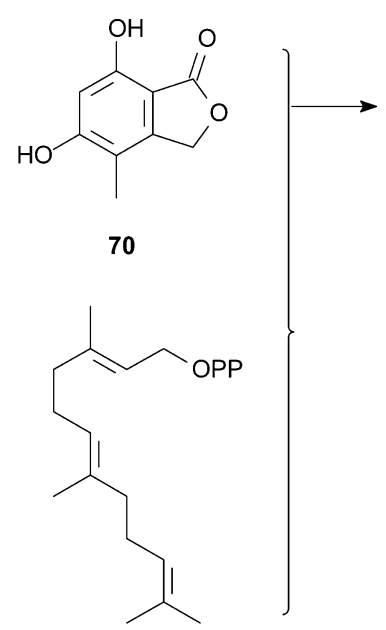

FPP<smiles>CC(C)=CCC/C(C)=C/CC/C(C)=C/Cc1c(O)c(C)c2c(c1O)C(=O)CO2</smiles>

150<smiles>CC(C)=CCCC1(C)OC1CCC(C)=CCc1c(O)c(C)c2c(c1O)C(=O)OC2</smiles><smiles>C[V]</smiles><smiles>CC(C)=CCCC(C)C(=O)CCC(C)=CCc1c(O)c(C)c2c(c1O)C(=O)OC2</smiles><smiles>CC(=CCc1c(O)c(C)c2c(c1O)C(=O)CO2)CCC=C(C)CCC(=O)O</smiles>

151
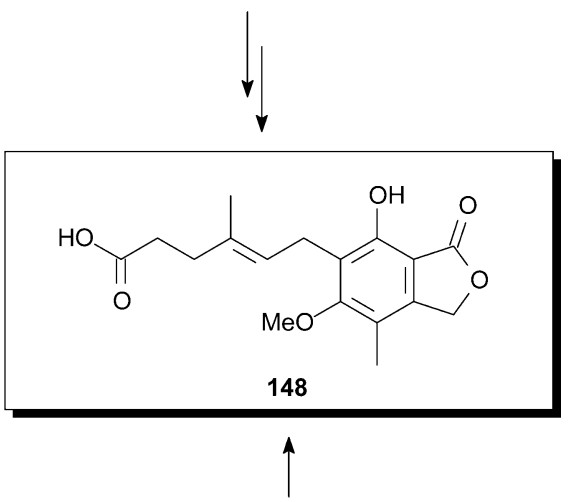<smiles>C/C(=C\Cc1c(O)c(C)c2c(c1O)C(=O)OC2)CCC(=O)O</smiles>

149<smiles>CC(=O)CCC=C(C)C</smiles><smiles>CC(C)=CCCC(C)(O)C(=O)CC/C(C)=C/Cc1c(O)c(C)c2c(c1O)C(=O)OC2</smiles>

Scheme 4 The proposed biosynthetic pathway to mycophenolic acid 148 (adapted from Muth and Nash ${ }^{77}$ and Colombo et al. ${ }^{79}$ ).

suggested sesterterpenoid origin was confirmed by stable-isotope labeling studies. ${ }^{86}$ Structurally, this compound consists of an $\alpha, \beta$ unsaturated- $\delta$-lactone as part of a spiro system in the A/B rings and a [4.3.1] bicyclic system (Scheme 6).

Subsequently, a large number of metabolites with a wide range of apparent structural diversity were shown to be closely related biosynthetically to 169: anditomin 170, austin 171 and terretonin 172. ${ }^{87}$ They are all formed via a common intermediate that arises by alkylation of a polyketide intermediate 3,5-dimethylorsellinate 71 by the terpenoid precursor farnesyl diphosphate. ${ }^{13}$ The mode of incorporation of the carbon skeleton in this intermediate into the metabolites described above is summarized in

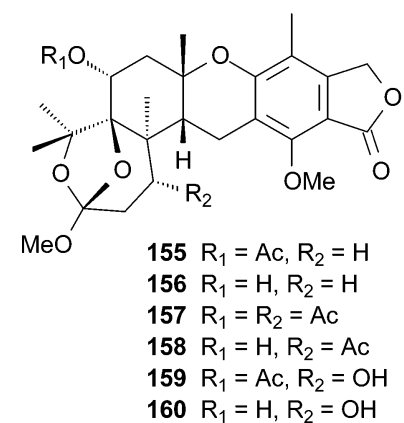

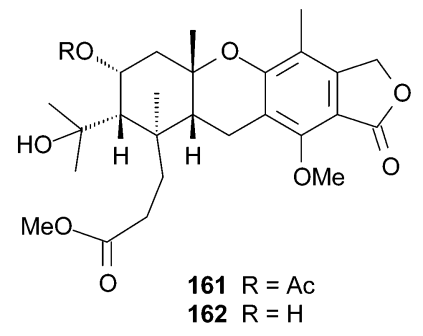<smiles>[R7]C1CC2(C)Oc3c(C)c4c(c(OC)c3C[C@H]2[C@]2(C)C(C)(C)OC(OC)CC[C@]12[2H])C(=O)OC4</smiles>

$163 \mathrm{R}_{1}=A c, \mathrm{R}_{2}=\mathrm{H}$

$164 \mathrm{R}_{1}=\mathrm{H}, \mathrm{R}_{2}=\mathrm{OH}$

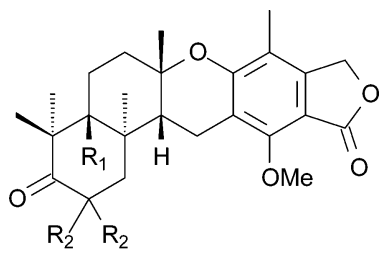

$165 \mathrm{R}_{1}=\mathrm{R}_{2}=\mathrm{H}$

$166 \mathrm{R}_{1}=\mathrm{OH}, \mathrm{R}_{2}=\mathrm{H}$ 


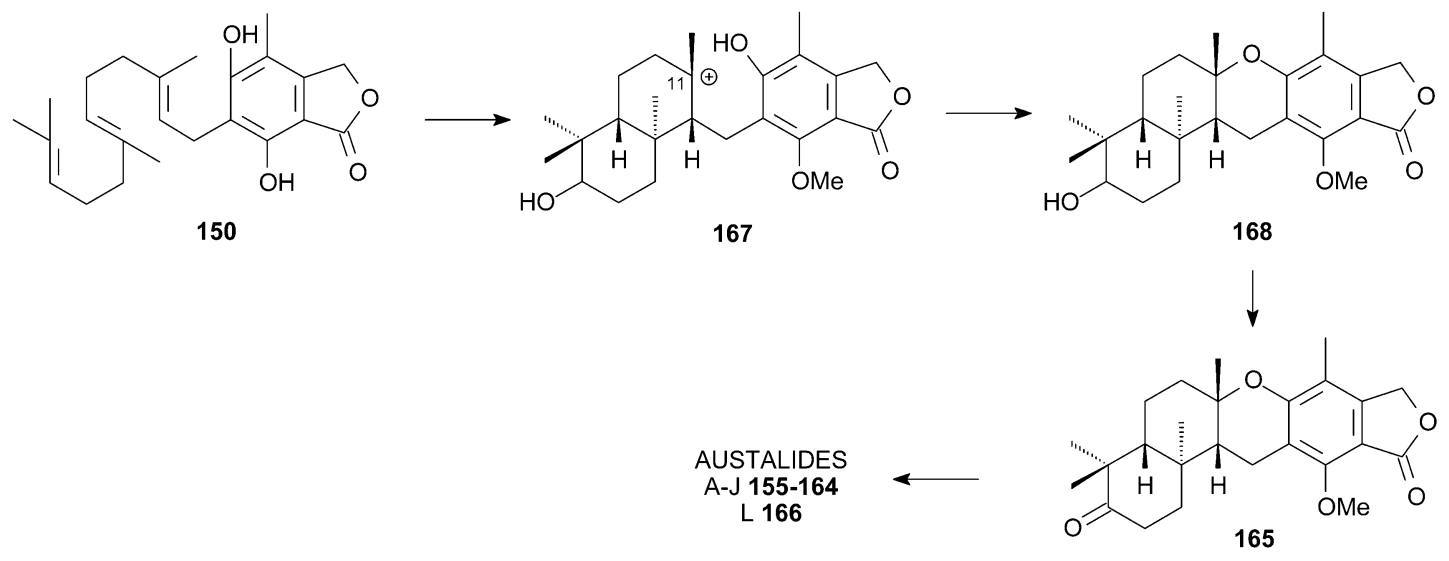

Scheme 5 The proposed biosynthetic pathway to the austalides.

Scheme 6. The carbocyclic ring can be incorporated intact (e.g. 169), cleaved (e.g. 170) or fragmented to an unprecedented degree (e.g. 171 and 172). ${ }^{13}{ }^{18} \mathrm{O}_{2}$-labelling studies, incorporation of aromatic precursors and mevalonic acids variously labeled with ${ }^{13} \mathrm{C},{ }^{2} \mathrm{H}$, and ${ }^{18} \mathrm{O}$ provided evidence for the extensive oxidative and other modifications involved in the elaboration of the highly oxygenated polycyclic structures found in these metabolites. ${ }^{86-88}$

Andilesins A $173,{ }^{89} \mathrm{~B} \mathbf{1 7 4},{ }^{90}$ and $\mathrm{C} 175^{90}$ were obtained from cultures of Aspergillus variecolor together with andibenins A 176, ${ }^{90}$ B $169{ }^{85}$ and $\mathrm{C} 177 .^{90}$ Their biosynthetic origin was confirmed by incorporation of ${ }^{13} \mathrm{C}$-labelled acetates and methionine ${ }^{87}$ As shown in Scheme 7, the key steps involves alkylation of a bis- $C$-methylated tetraketide-derived phenolic precursor $\mathbf{7 1}$ by farnesyl pyrophosphate to give intermediate 178, followed by drimane-type cyclization of the farnesyl moiety to $\mathbf{1 7 9}$, followed by intramolecular $4+2$ cycloaddition to produce the bicycloctane part of the carbon skeleton of intermediate 180. Further oxidative modifications and rearrangements lead to $\mathbf{1 7 3}$ which is converted by dehydratation into andilesin B 174 and then reduction to andilesin C 175. ${ }^{91}$
Rearrangement of the 7-membered lactone ring in the andilesins would form the spiro-lactone found in the corresponding andibenins. This has been proposed to proceed via alkyl-oxygen cleavage and loss of the C-5 proton to form a tetra-substituted alkene, epoxidation of which allows the skeletal rearrangement required to form the spiro- $\delta$-lactone. ${ }^{87}$

Four cytotoxic meroterpenoids with andilesin-like structures, tropolactones A-D 181-184, ${ }^{92}$ have been isolated from the whole-broth extract of a marine-derived Aspergillus species. These compounds seem to be derived from the same triene intermediate 179 in andilesin and andibenin biosynthesis. Pyran ring formation after tautomerization to enol $\mathbf{1 8 5}$ would give 186, followed by oxidation to form the sevenmembered ring lactone to give 187, the precursor of tropolactone D. Hypothetically, the ring expansion in tropolactones $\mathrm{A}-\mathrm{C}$ proceeds by a radical cyclopropanation mechanism to give stabilized radical intermediate 188, which can then undergo ring expansion to provide tropolone 189, from which further oxidative modifications result in 181-183 (Scheme 8). ${ }^{92}$
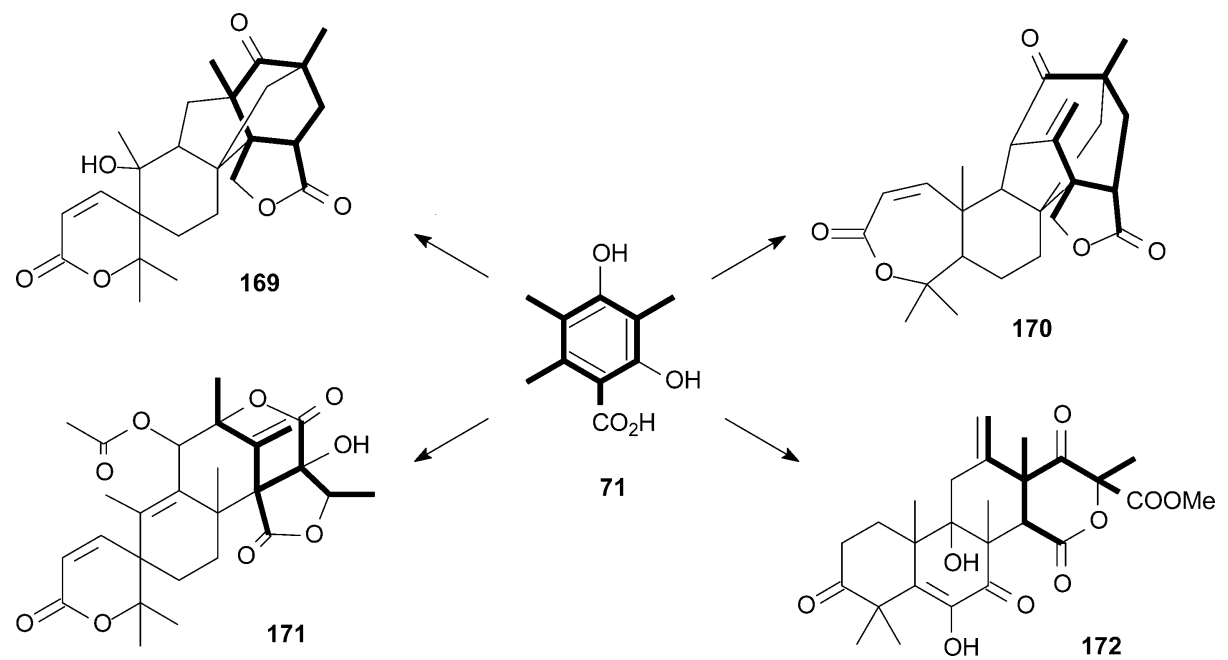

Scheme 6 The mode of incorporation of the carbon skeleton of 3,5-dimethylorsellinic acid. 

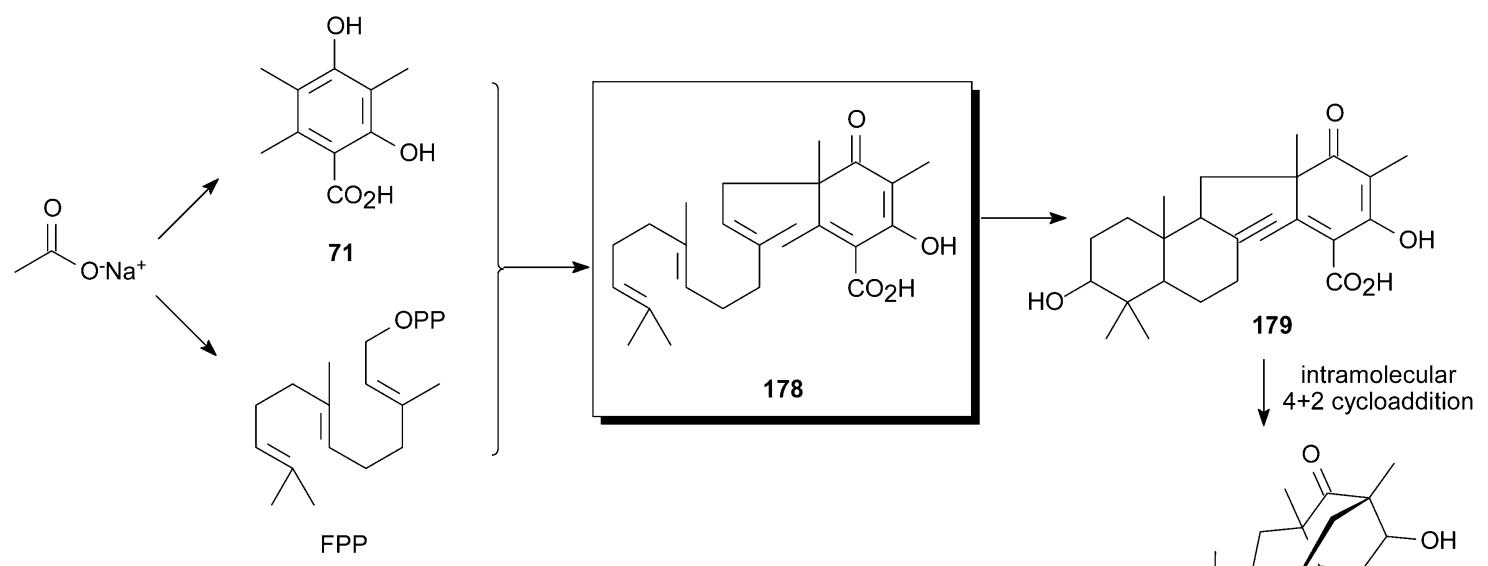

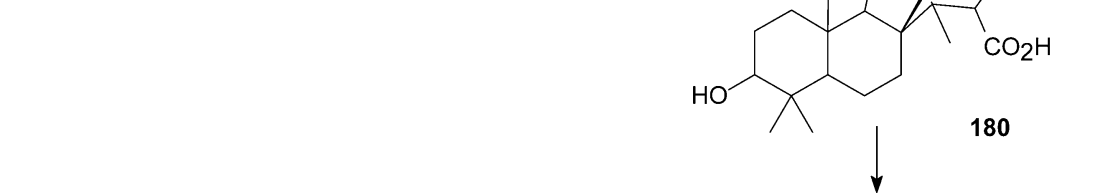

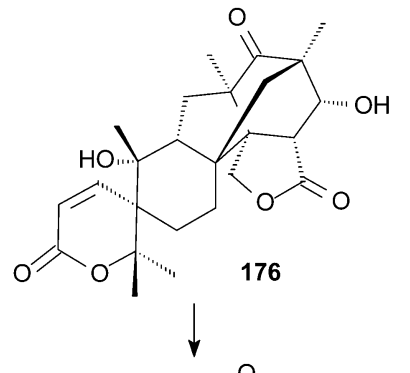

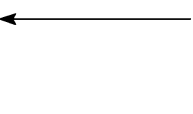

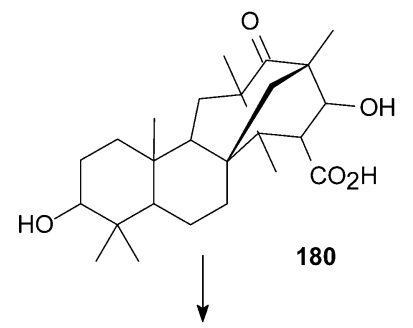

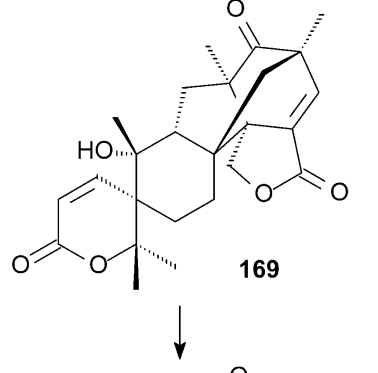

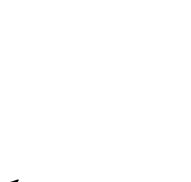

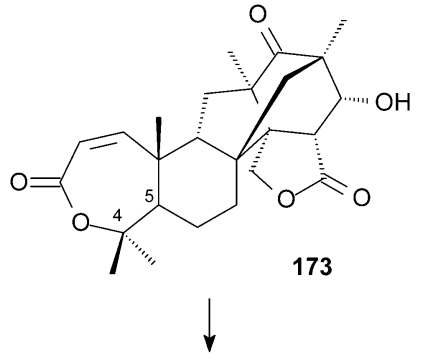

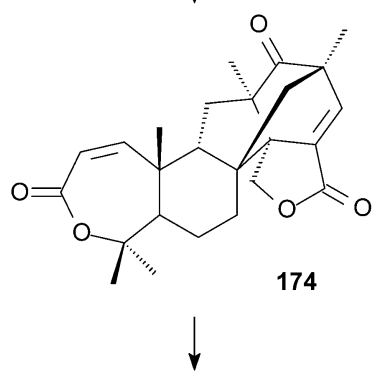

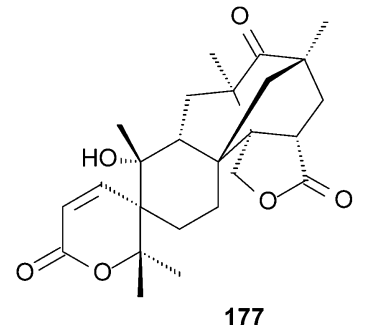

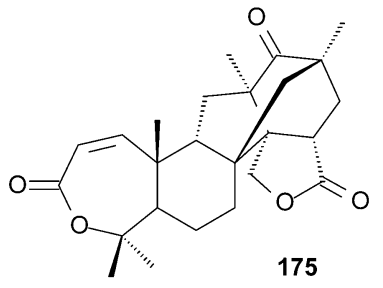

Scheme 7 Proposed biosynthetic pathway to the andilesins and andibenins.

Anditomin 170 was isolated from $A$. variecolor and had its structure deduced from ${ }^{1} \mathrm{H},{ }^{13} \mathrm{C} \mathrm{NMR}$ and X-ray crystallography. ${ }^{93}$ This compound represents an important modification of the meroterpenoid pathway, as it was the first metabolite in which the carbocyclic ring of the tetraketide-derived moiety had been fragmented, ${ }^{87}$ representing a novel skeletal rearrangement in this class of compounds. Anditomin is closely related to andilesin $\mathrm{C} \mathrm{175}$, differing only in an exocyclic methylene group at C-9'. It could be obtained by the loss of hydrogen from C-11 to produce the carbocation 190, which can rearrange to form the exocyclic methylene 191, as shown in Scheme 9.
Fumigatonin 192 was isolated from cultures of $A$. fumigatus IFM 4482. ${ }^{1} \mathrm{H}$ and ${ }^{13} \mathrm{C}$ NMR spectra suggested that fumigatonin contains a highly oxidized and complicated condensed ring system. ${ }^{94}$ The detailed structure, as well as the relative stereochemistry of 192, was established by X-ray analysis. It seems to be a meroterpenoid formed by a novel variation of the same key intermediate 179, followed by fragmentation of C-4'-C-5' bond and successive oxidative processes. Aspergillus novofumigatus, a newly characterized Aspergillus species, when cultivated on YES agar, produced the fumigatonin-related compound novofumigatonin 193. The major difference between them is the 
<smiles>CC(=O)C1=C(C)C(C)(C[C@H]2C(=O)CC[C@H]3[C@H](C)C(C)(C)C(O)CC[C@]32C)C(O)=C(C)C1=O</smiles>

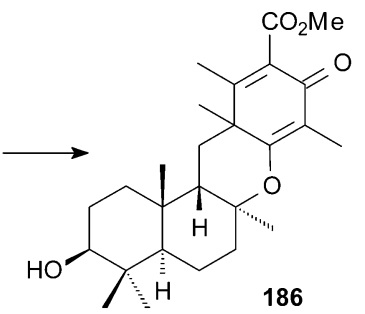

[O] $\downarrow$ Baeyer-Villiger<smiles>CCCC1CC[C@]2(C)Oc3c(cc(C)c(C(C)=O)c(=O)c3C)C[C@H]2C1(C)CC</smiles>

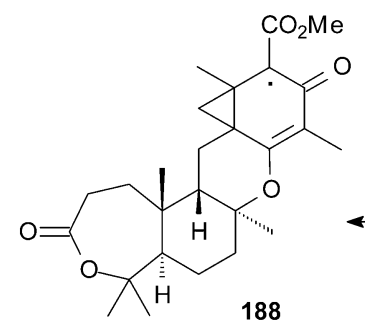<smiles>CC(=O)C1=C(C)C2(C)C[C@]3(C)C(CCC(=O)OC3(C)C)O[C@@]2(C)CC[C@H]1C(C)=O</smiles><smiles>[R]OC=[R]OC(C)=[18O]</smiles>

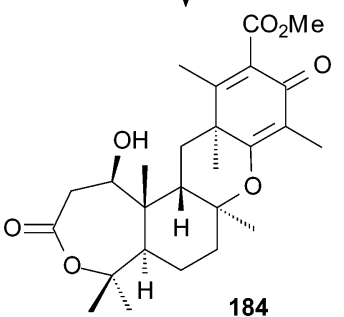

Scheme 8 Proposed biosynthetic pathway to the tropolactones.

presence of an aldehyde substituent on C-10 in $\mathbf{1 9 3}$ (where $\mathbf{1 9 2}$ has an oxygen-bound methylene group) and the lack of an acetate group at C-6 in 193. ${ }^{95}$

Investigation of a strain of Aspergillus ustus found on stored eyed-peas resulted in the isolation of a mycotoxin named austin 171 whose structure was determined by X-ray crystallography. ${ }^{96}$ Further closely related metabolites austinol 194 and dehydroaustin 195 were also isolated from this fungus. ${ }^{97}$ The latter has also been found in cultures of a mutant strain of $A$. variecolor. ${ }^{98}$ In addition, isoaustin 196 was obtained from the culture liquors of Penicillium diversum. ${ }^{97}$

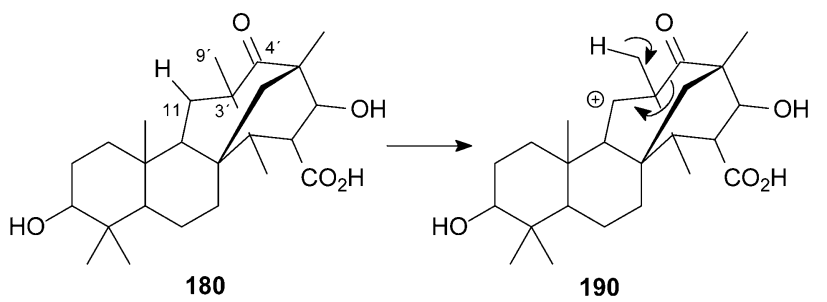

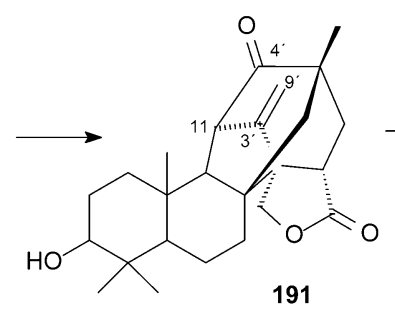

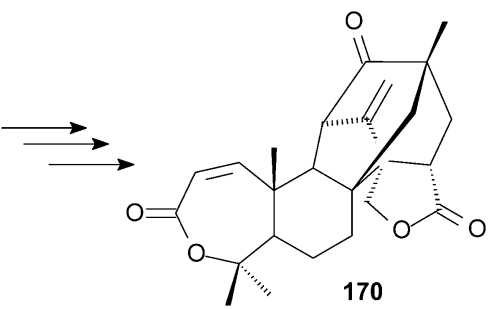

Scheme 9 The proposed biosynthetic pathway for anditomins.

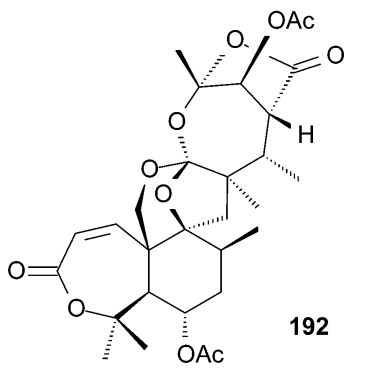

Subsequently, a number of compounds chemically related to austin were found in a variety of fungal cultures, such as dehydroaustinol 197 from Emericella dentata, and acetoxydehydroaustin 198 and neoaustin 199 from Penicillium sp MG11. ${ }^{99}$ Chemical investigations of the fungus Penicillium $\mathrm{sp}$ LaBioMi-024 found in association with Melia azedarach led to the isolation of 10 novel related meroterpenoids in addition to the known 195, 198 and 199. These are preaustinoids A 200, ${ }^{100}$ A1 201, A2 202, ${ }^{101}$ A $3 \mathbf{2 0 3},{ }^{102}$ B 204, ${ }^{100}$ B1 $205^{101}$ and B2 206, ${ }^{102}$ austinoneol 207, ${ }^{103}$ isoaustinone 208 and austinolide 209. ${ }^{102}$ 


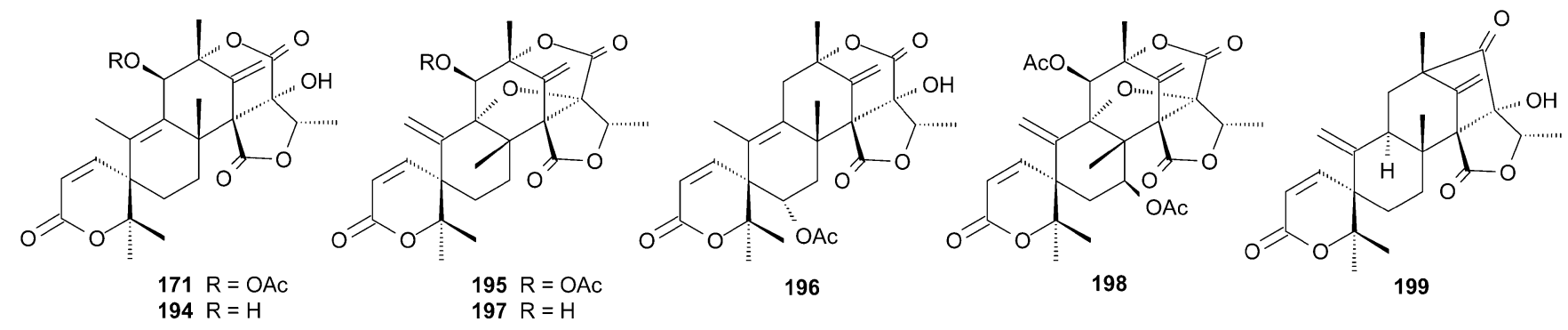

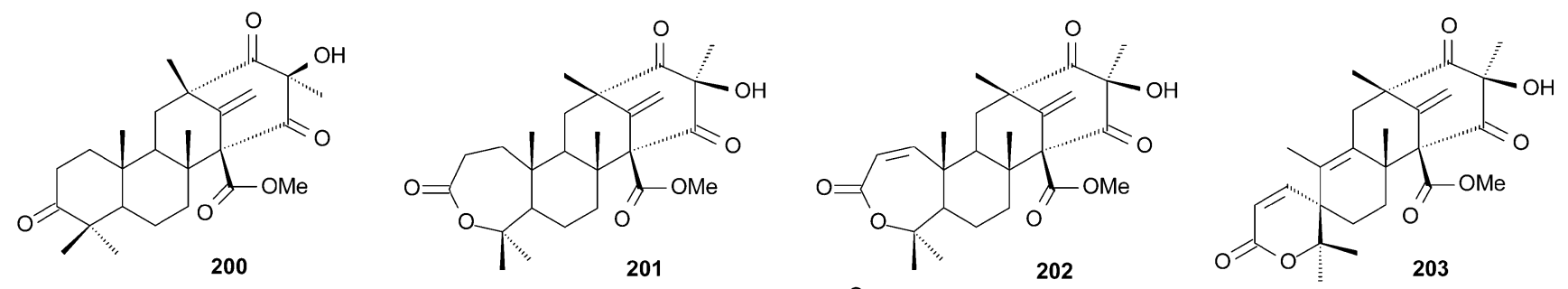
200

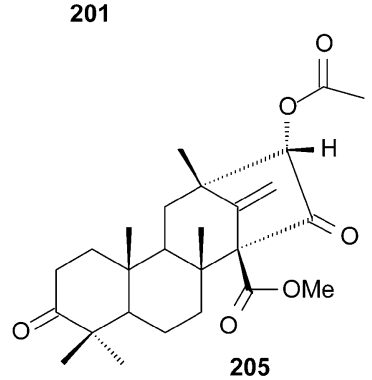

202

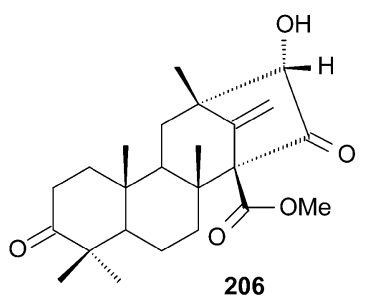

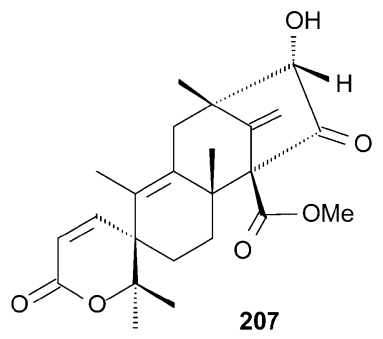

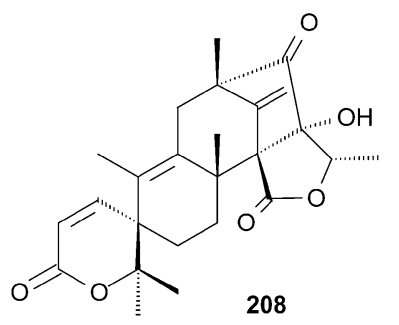

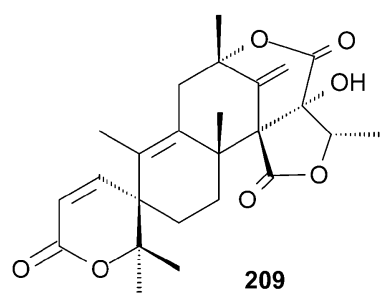

A few biological activities have been reported for this group of compounds. Meroterpenoids 171, 195 and 198, although not active themselves, enhanced the convulsive activity of verruculogen in a silkworm bioassay. ${ }^{99}$ Moderate bacteriostatic effects were detected for 204 and 208. ${ }^{100}$ Recently, some of these compounds were evaluated for larvicidal activity against Aedes aegypti; 171, 195 and 198 exhibited some activity, especially dehydroaustin 195, which showed remarkable potential for controlling this mosquito. ${ }^{104}$

Studies on the biosynthesis of the austin group of meroterpenoids produced by Aspergillus and Penicillium have suggested that this group of metabolites is also formed by C-alkylation of $\mathbf{7 1}$ by farnesyl pyrophosphate. Alkylation leads to intermediate 178, which cyclises to form a 1,3-diketone 210, as shown in Scheme 10.87,105,106 Further information about the mechanisms involved in the drastic modifications of the tetraketide- and farnesyl-derived modifications have been provided by extensive studies with ${ }^{13} \mathrm{C}$-, ${ }^{2} \mathrm{H}$-, and ${ }^{18} \mathrm{O}$-labelled precursors. $^{87,105}$ The structures of the compounds obtained from the cultures of Penicillium sp. LaBioMi-024 provide support for this general route. ${ }^{102}$
Paraherquonin 211 was isolated from Penicillium paraherquei IFO6234 and its structure determined by X-ray diffraction analysis. ${ }^{107}$ The pathway to $\mathbf{2 1 1}$ seems to be an extension of the austin pathway to form $\mathbf{2 1 1}$ through further modification by oxidative cleavage, migration, decarboxylation and recyclization. ${ }^{107}$

Two bioactive meroterpenoids berkeleydione 212 and berkeleytrione $\mathbf{2 1 3}$ were obtained from cultures of Penicillium rubrum Stoll found growing in Berkeley Pit Lake. ${ }^{108}$ Both compounds inhibited matrix metalloproteinase-3 and caspase-1; 212 also showed activity toward non-small-cell lung cancer in NCI's human cell line antitumor screen. Further studies using ${ }^{1} \mathrm{H}$ NMR analysis of all of the column fractions led to the isolation of the related analogues berkelyacetals A 214, B 215, and C 216. ${ }^{109}$ The latter was accepted in the NCI Developmental Therapeutics Program for human cell line screening and tested in the singledose-response assay due to its inhibition of the growth of nonsmall-cell lung cancer NCI H460, the same cell line that was targeted by $\mathbf{2 1 2} .{ }^{109}$

Cultivation of the marine fungus Penicillium minioluteum resulted in the production of 22-epoxyberkeleydione 217, 
<smiles>Cc1c(C)c(O)c(C(=O)O)c(O)c1C</smiles>

71<smiles>CCCOCCC=C(C)CCC=C(C)C</smiles>

FPP
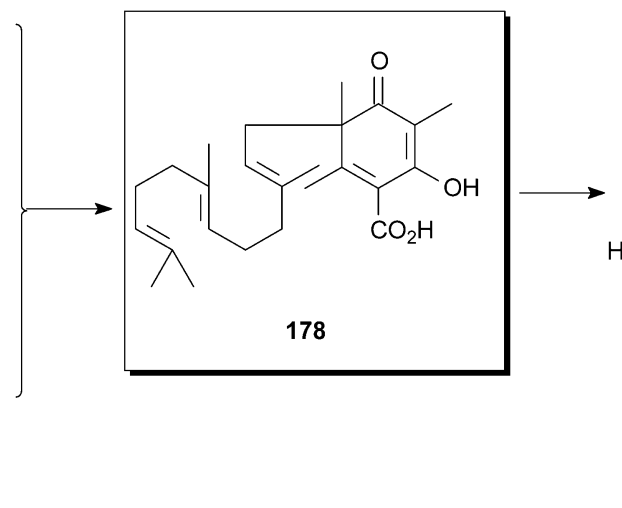

Meroterpenoids 205, 206 and 207

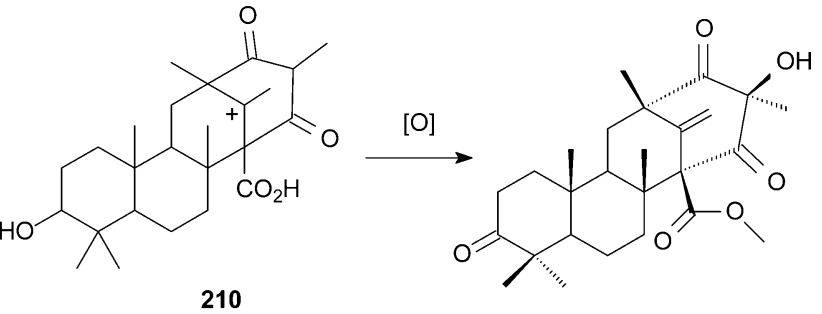

210

200

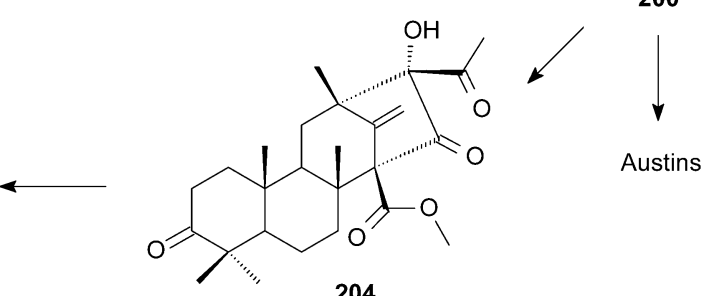

204

Scheme 10 Proposed biosynthesis of meroterpenoids produced by species of the genera Aspergillus and Penicillium.

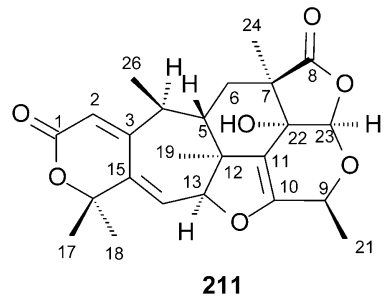

211

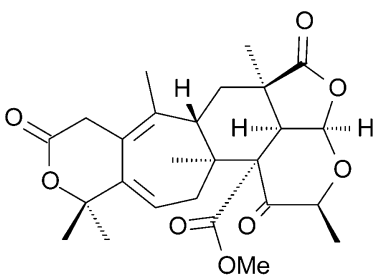

214<smiles>C=CC[C@]12C(=O)C3(C)OC(=O)CC3=C(C)C1C[C@]1(C)C(=O)[C@](C)(O)C(=O)[C@]12C(=O)OCC</smiles>

212

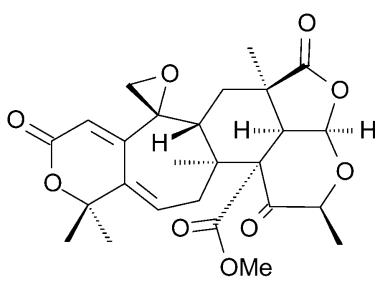

215

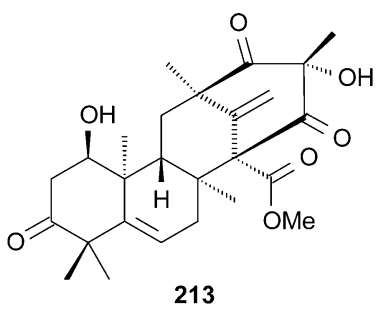

213

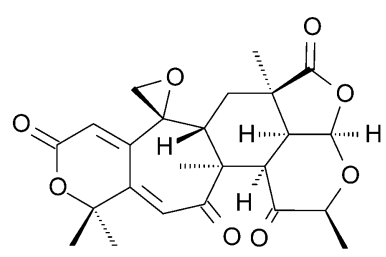

216 miniolutelide A 218, and miniolutelide B 219. ${ }^{110}$ Their structures were determined by NMR spectroscopic analyses and X-ray crystallography.

The proposed biosynthetic pathway for this group of compounds is shown in Scheme 11. An epoxide-initiated cyclization of 178 generates a tetracyclic intermediate 220 ( $c f$. 210) from which oxidative transformations give rise to berkeleytrione 213. ${ }^{110}$ Berkeleydione 212 is supposed to be produced from 213 by a Baeyer-Villiger type oxidation of the A-ring ketone and a subsequent 1,2-alkyl shift to form a cycloheptadiene B-ring. Epoxidation of the exo-methylene produces 217, which is converted to 221 via retro-Claisen cleavage of C-8/C-9 and hydrolysis of the epoxide followed by oxidation of the resulting primary alcohol to an aldehyde. Acetal lactonization and introduction of a hydroxyl group at C-13 yields 222, which forms another acetal between the 13-OH and the 10-ketone, affording miniolutelide B 219. Miniolutelide A 218 results from migration of the methoxycarbonyl group (C-20) to the 9-OH on 222 by<smiles></smiles>

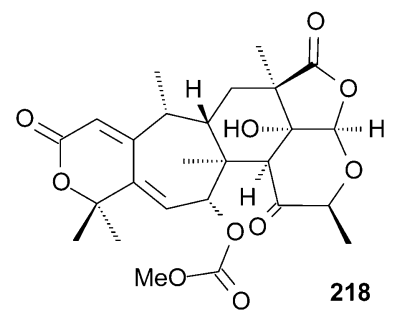

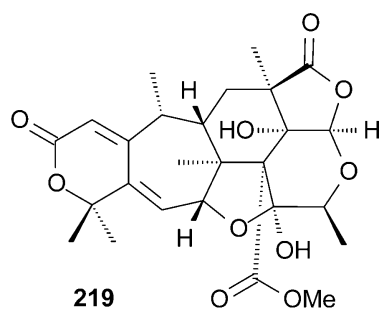




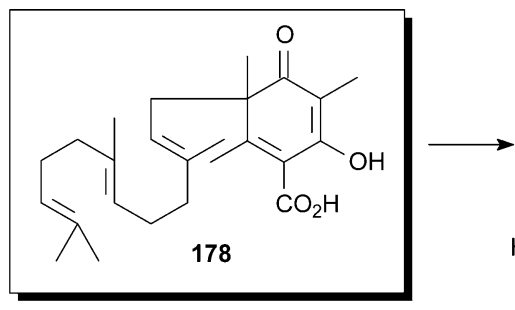

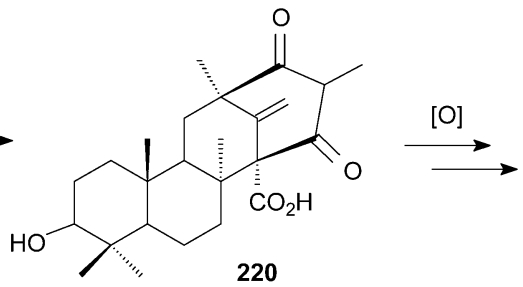

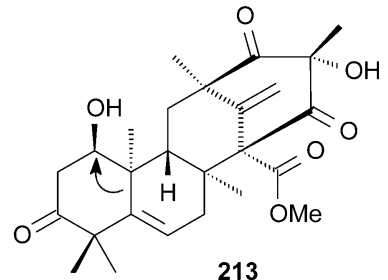

220

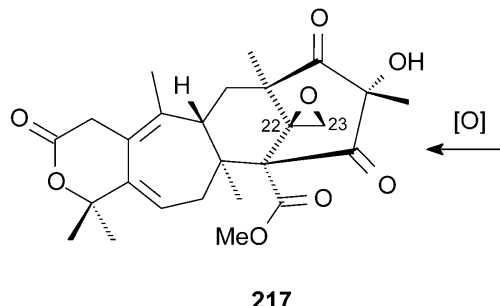<smiles>COC(=O)[C@@]12C(=O)[C@@](C)(O)C(=O)[C@@]1(C)CC1C(C)=C3CC(=O)OC(C)(C)C3=CC[C@]12C</smiles>

221

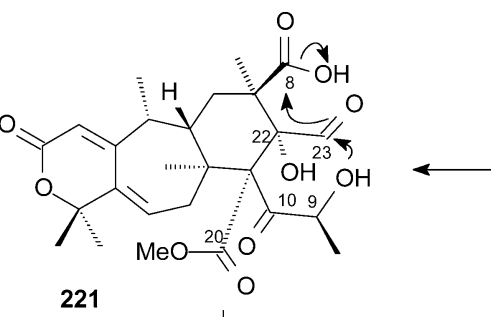

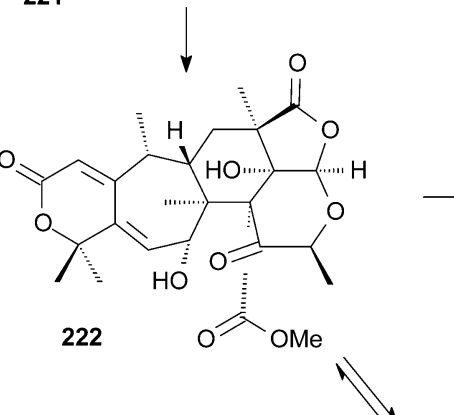

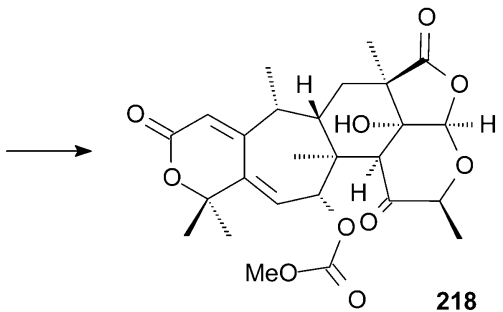

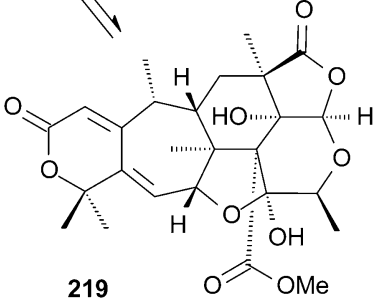

Scheme 11 Proposed biosynthetic pathway of berkeleyones and related compounds.

intramolecular retro-Claisen condensation. ${ }^{110}$ From this it can be proposed that $\mathbf{2 1 7}$ is the precursor for the berkelyacetals 214-216 and that the meroterpenoid $\mathbf{2 1 9}$ may be the precursor for paraherquonin 211.

Four new protein farnesyltransferase inhibitors, andrastins AD 223-226, have been isolated from a cultured broth of Penicillium sp. Fo-3929. ${ }^{111,112}$ The structure of $\mathbf{2 2 3}$ was elucidated by INADEQUATE, ${ }^{13} \mathrm{C}-{ }^{13} \mathrm{C}$ coupling constants and X-ray crystallographic analysis, and its skeleton was shown to be based on

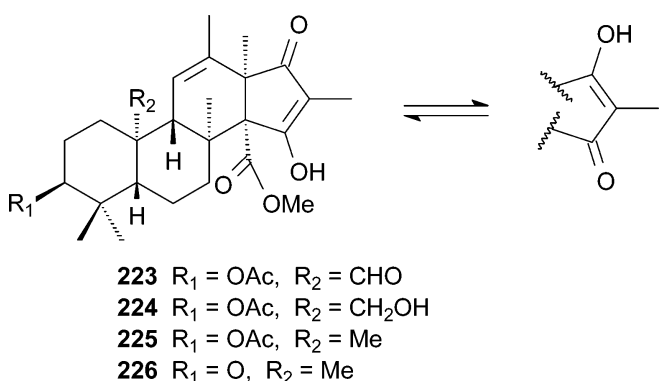

ent-5 $\alpha, 14 \beta$-androstane. ${ }^{113}$ The structures of the other compounds were also elucidated by NMR. ${ }^{112,113}$

The results of incorporation studies suggested that these compounds share the same key austin intermediates 178 and 210. As shown in Scheme 12, ring contraction of 210 with subsequent $\mathrm{H}-11$ proton loss would produce the andrastin precursor 227 with an endocyclic double bond at C-11-C-3'. ${ }^{113}$

A number of metabolites, the citreohybridones, have been isolated from the mycelium of a hybrid strain $\mathrm{KO} 0031$ derived from Penicillium citreo-viride B. IFO 6200 and 4692. After a combination of extensive spectroscopic data analysis, chemical evidence and absolute configuration determination, their structures were elucidated as citreohybridones A-G 229-235, ${ }^{114,115}$ J-L 236-238, ${ }^{116}$ isocitreohybridones A-C 239-241, ${ }^{\mathbf{1 1 6}, 117}$ G-I 242-244, ${ }^{115,118}$ citreohybridiones A-C 245-247 ${ }^{117,119}$ and citreohybridonol 248. ${ }^{120}$ Citreohybridonol 248 exists in an equilibrium between two different ring $\mathrm{D}$ tautomers. These have potent antifeedant activity against the diamond-back moth Plutella xylostella. ${ }^{118}$ 

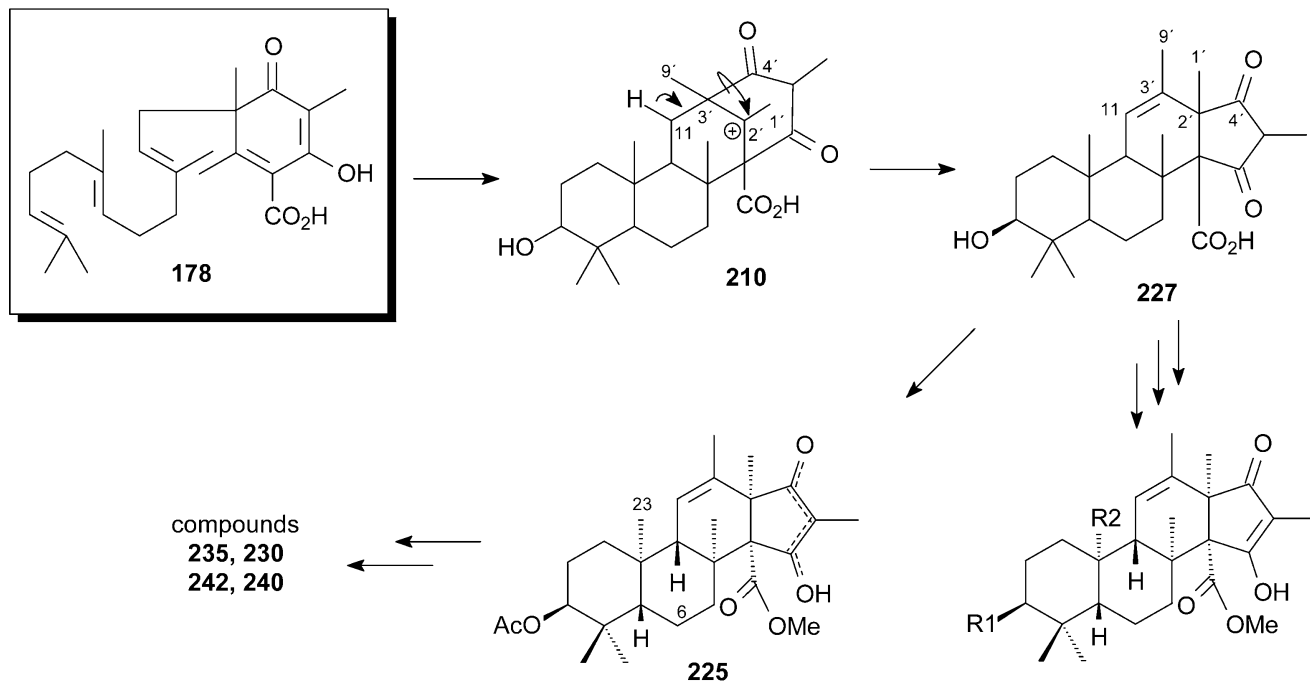<smiles>[V]C1CCCCC1</smiles>
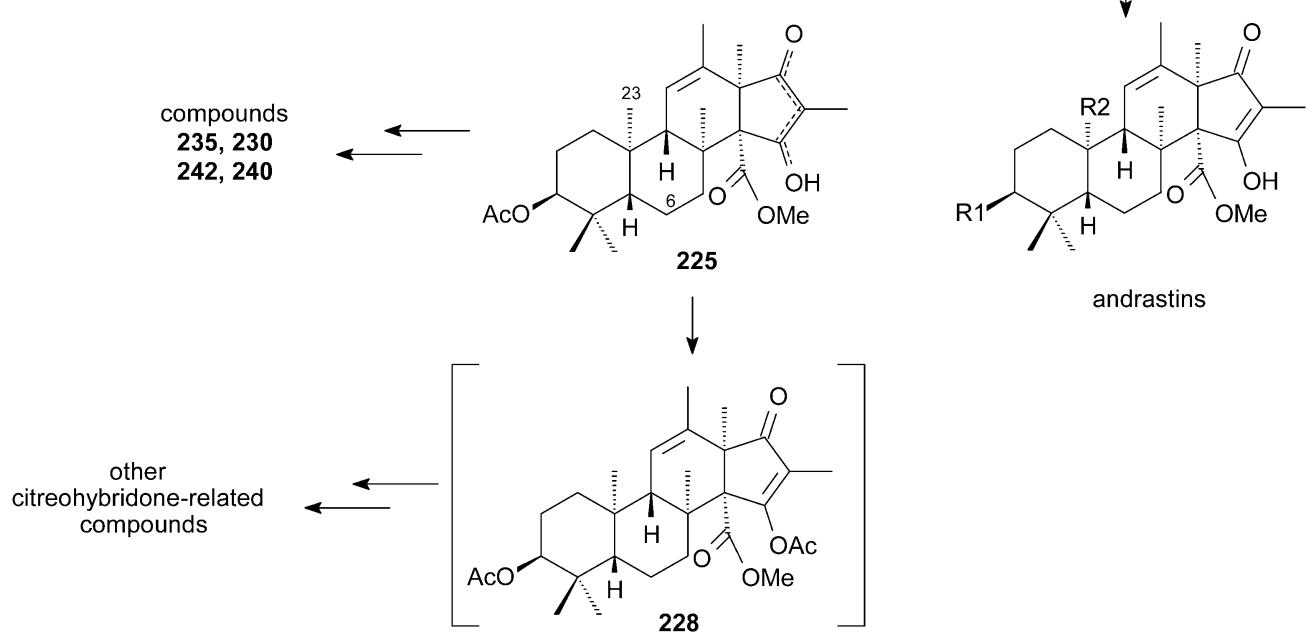

andrastins

Scheme 12 Proposed biosynthetic pathway for andrastins and citreohybridones.

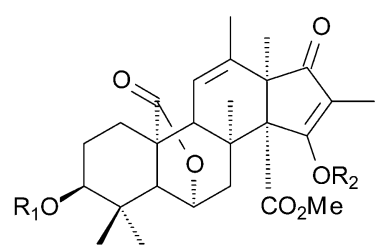

$229 \mathrm{R}_{1}=\mathrm{R}_{2}=\mathrm{OAC}$

$230 \mathrm{R}_{1}=\mathrm{OAc}, \mathrm{R}_{2}=\mathrm{Me}$

$231 \mathrm{R}_{1}=\mathrm{H}, \mathrm{R}_{2}=\mathrm{Me}$

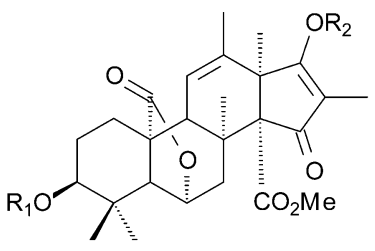

$239 \mathrm{R}_{1}=\mathrm{R}_{2}=\mathrm{OAC}$

$240 \mathrm{R}_{1}=\mathrm{OAc}, \mathrm{R}_{2}=\mathrm{Me}$

$241 \mathrm{R}_{1}=\mathrm{H}, \mathrm{R}_{2}=\mathrm{Me}$

$243 R_{1}=O A c, R_{2}=E t$

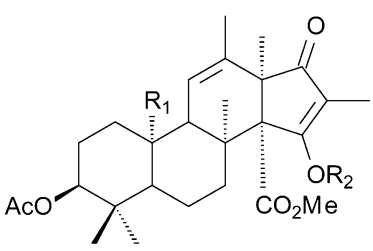

$232 \mathrm{R}_{1}=\mathrm{CHO}, \mathrm{R}_{2}=\mathrm{OAC}$

$233 \mathrm{R}_{1}=\mathrm{CO}_{2} \mathrm{H}, \mathrm{R}_{2}=\mathrm{OAC}$

$234 \mathrm{R}_{1}=\mathrm{CO}_{2} \mathrm{Me}, \mathrm{R}_{2}=\mathrm{OAC}$

$235 \mathrm{R}_{1}=\mathrm{CHO}, \mathrm{R}_{2}=\mathrm{Me}$

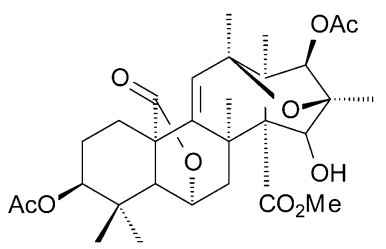

236
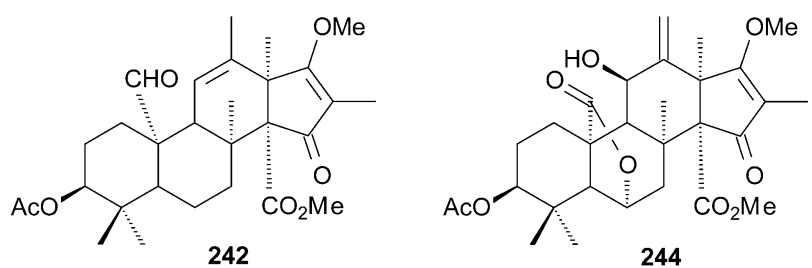

244

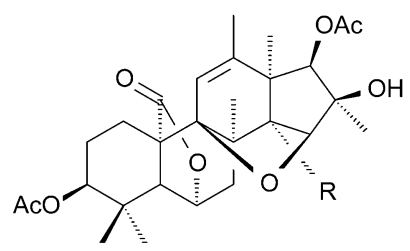

$237 \mathrm{R}=\mathrm{CO}_{2} \mathrm{Me}$

$238 \mathrm{R}=\mathrm{CH}_{2} \mathrm{OAC}$

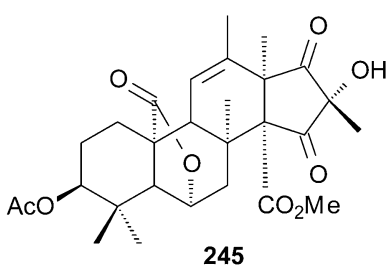

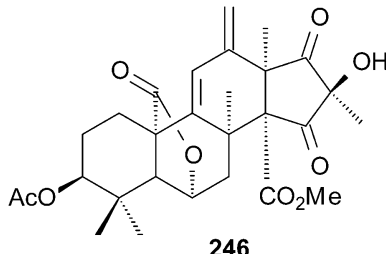

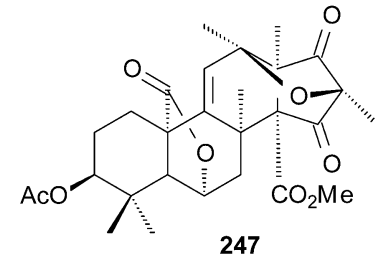




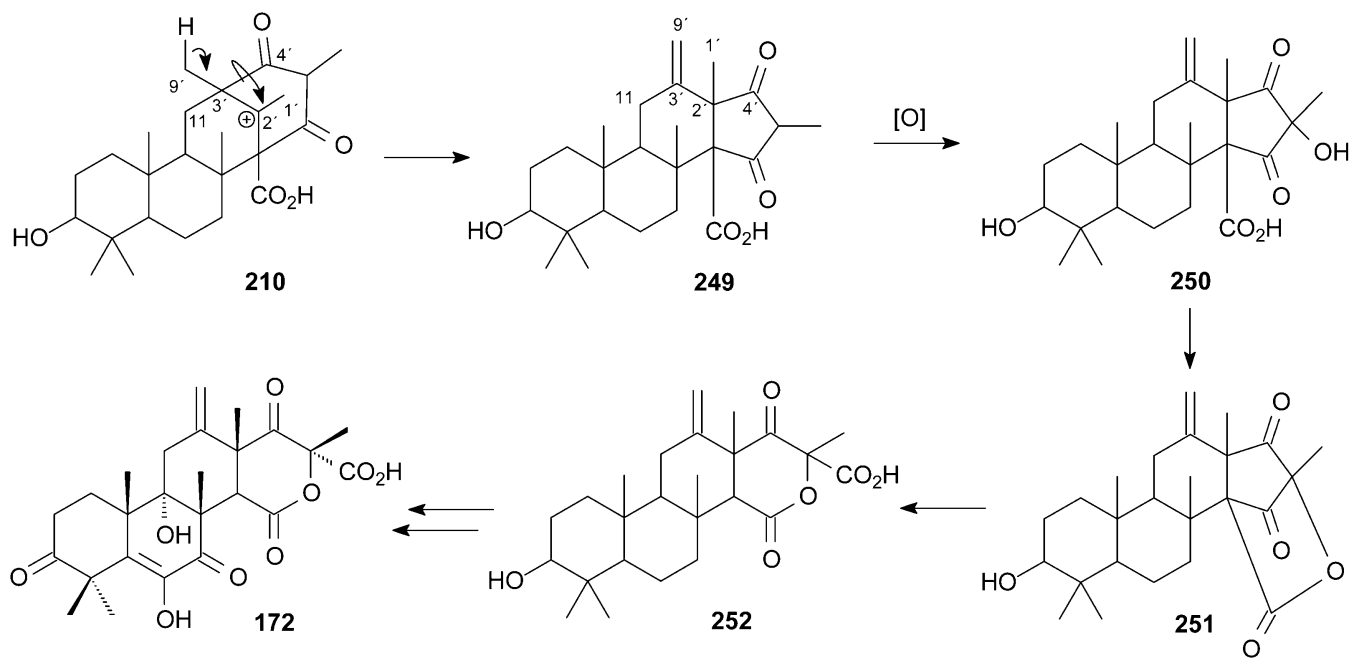

Scheme 13 Proposed biosynthetic pathway to terretonin 172.

Incorporation of ${ }^{13} \mathrm{C}$-labelled acetate, formate and 3,5-dimethylorsellinate into citreohybridones confirmed that their biosynthesis proceeds via a mixed polyketide-terpenoid pathway. ${ }^{120,121}$ Thus, andrastins must be precursors of citreohybridones, as shown in Scheme 12.115,118

Terretonin 172 was originally isolated in very low yields from a toxigenic strain of Aspergillus terreus (NRRL 6273) grown on a medium of shredded wheat in mycological broth supplemented with sucrose and yeast extract. ${ }^{122}$ However, 172 could be more conveniently isolated from liquid cultures using a medium based on malt extract broth, and then complete assignments of the ${ }^{1} \mathrm{H}$ and ${ }^{13} \mathrm{C}$ NMR spectra were made using a variety of $1 \mathrm{D}$ - and $2 \mathrm{D}$ correlation methods. ${ }^{123}$

The biosynthetic pathway to $\mathbf{1 7 2}$ was first proposed by McIntyre et al. ${ }^{124}$ with incorporation of labelled precursors suggesting the same key austin intermediate 210. However, the degree of modification of the orsellinate moiety is even more drastic in 172. Additional experiments with precursors doubly labelled with ${ }^{13} \mathrm{C}$ and ${ }^{18} \mathrm{O}$ allowed the biosynthetic proposal shown in Scheme 13. ${ }^{125}$ The formation of the C/D rings involves an acyl shift with the loss of a proton to generate the required exocyclic double bond in 249. Aerobic hydroxylation to $\mathbf{2 5 0}$, intramolecular lactonization to $\mathbf{2 5 1}$ and retro-Claisen carboncarbon bond cleavage would afford an intermediate carboxylic acid 252. Oxidation to introduce the desired functionality in the A/B ring system and methylation of the free carboxylic acid by methionine would give $\mathbf{1 7 2} .^{125}$

Two additional compounds exhibiting a D-ring seco-meroterpenoid skeleton as in terretonin $\mathbf{1 7 2}$ were isolated from Penicillium simplicissimum and named penisimplicin A 253 and B 254. ${ }^{126}$ Their absolute structures were established by spectroscopic and chemical investigation. Their stereochemistries were confirmed by the exciton chirality method (through benzoylation of a synthetic derivative of $\mathbf{2 5 3}$ with an excess of $p$-bromobenzoyl chloride to give the 6,7-di- $p$-bromobenzoate derivative), confirming, thus, the stereochemistries $6 R$ and $7 R$ for 253 .

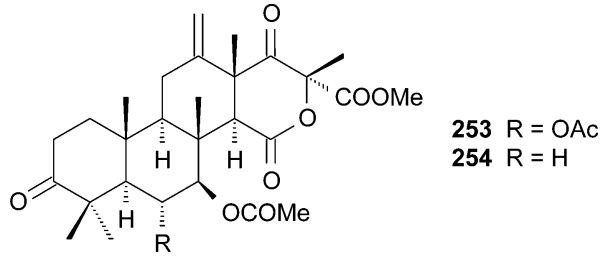

From the results discussed above it becomes clear that the 3,5-dimethylorsellinate-based meroterpenoid pathway can be seen to be relatively widespread in fungi. Moreover, meroterpenoids produced by Aspergillus and Penicillium that incorporate 3,5-dimethylorsellinate $\mathbf{7 1}$ seem to share the same key intermediate $\mathbf{1 7 8}$ to produce the large variety of compounds described here with obvious structural relationships. The likely biosynthetic relationships between these structurally varied metabolites were first proposed by Simpson ${ }^{127}$ and updated to add the intermediate for andrastin, citreohybridone and terretonin biosynthesis. ${ }^{87}$ Herein, this scheme has been extended to include the other intermediates involved in biosynthetic pathways of the additional meroterpenoids reported in the literature (Scheme 14).

\subsection{Derived from other tetraketides}

During the course of a search for fruit rot phytotoxins produced by the fungus Botryosphaeria berengeriana, a causal agent of fruit rot of apple, a series of compounds designated as macrophorins A-G 255-261 were isolated. ${ }^{128-130}$

Apart from macrophorin F 260, these meroterpenoids consist of a drimene sesquiterpene and a C-7-epoxycyclohexenone moiety, while 260 has a C-7-hydroxycyclohexenedione presumably derived as a result of rearrangement of the epoxide. ${ }^{130}$ Antimicrobial and cytotoxic activity was observed for macrophorin A 255, ${ }^{\mathbf{1 2 8 - 1 3 0}} \mathbf{2 5 7}$ exhibited self-growth inhibiting activity, ${ }^{129}$ and 259 was potently active against phytopathogenic fungi. ${ }^{130}$ 


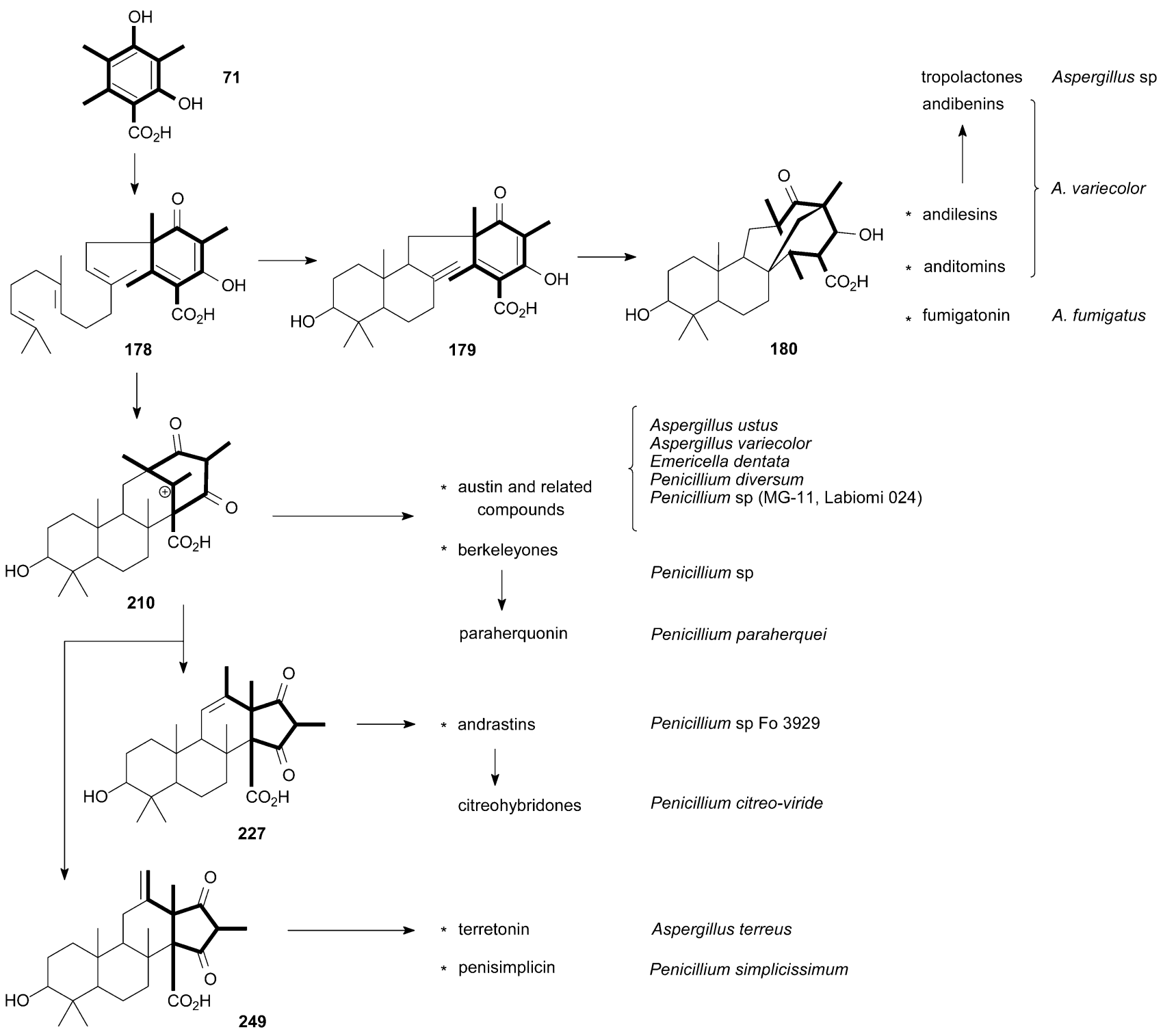

Scheme 14 The extended fungal meroterpenoid pathway.

A strain of Helminthosporium siccans, a parasitic organism of rye grass, gave the phenolic antibiotic siccanin $262 .{ }^{131}$ Its structure was determined by X-ray diffraction. ${ }^{132}$ Subsequent work on the culture broth of this microorganism allowed the isolation of siccanochromenes A-H 263-270, siccanochromenic acid 271 and presiccanochromenic acid 272, which were presumed to be possible biosynthetic intermediates of 262. . $^{133-135}$

The biosynthetic pathway (Scheme 15) to $\mathbf{2 6 2}$ is based on experiments using cell-free systems and intact<smiles></smiles>

$255 R_{1}=R_{2}=H$

$258 \mathrm{R}_{1}=\mathrm{H}, \mathrm{R}_{2}=\mathrm{COCH}_{2} \mathrm{C}(\mathrm{OH})\left(\mathrm{CH}_{3}\right) \mathrm{CH}_{2} \mathrm{COOH}$

$259 \mathrm{R}_{1}=\mathrm{H}, \mathrm{R}_{2}=\mathrm{COCH}_{2} \mathrm{COOH}$

$261 \mathrm{R}_{1}=\mathrm{COCH}_{2} \mathrm{COOH}, \mathrm{R}_{2}=\mathrm{H}$<smiles></smiles>

256<smiles>C=C1CC[C@H]2C(C)(C)[C@H](O)CC[C@]2(C)C1CC12OC1C(=O)C=C2CO</smiles>

257<smiles>C=C1CC[C@H]2C(C)(C)CCCC2(C)C1C[C@]1(O)CC(=O)C(COC(=O)CC(=O)O)=CC1=O</smiles>

260 
<smiles>Cc1cc(O)c2c(c1)O[C@H]1CC[C@H]3C(C)(C)CCC[C@]3(C)C1COC2</smiles>

262<smiles>C=C1CCCC(C)(C)[C@@H]1CC[C@H]1C=Cc2c(O)cc(C)cc2O1</smiles><smiles>Cc1cc(O)c2c(c1)O[C@@H](CC[C@H]1C(C)(C)CCCC13CO3)C=C2</smiles><smiles>Cc1cc(O)c2c(c1)O[C@H](CC[C@H]1C(CO)=CCCC1(C)C)C=C2</smiles><smiles>Cc1cc(O)c2c(c1)OC(CC[C@H]1C(CO)CCCC1(C)C)C=C2</smiles><smiles>Cc1cc(O)c2c(c1)O[C@H]1CC[C@H]3C(C)(C)CCC[C@]3(CO)C1=C2</smiles><smiles>Cc1cc(O)c2c(c1)O[C@H](CC[C@H]1C(C)(C)CCCC1(O)CO)C=C2</smiles><smiles>Cc1cc(O)c2c(c1)O[C@H](CC[C@H]1C(C(=O)O)CCCC1(C)C)C=C2</smiles><smiles>Cc1cc(O)c2c(c1)O[C@](C=O)(CC[C@@H]1C(C=O)CCCC1(C)C)C=C2</smiles><smiles>C=C1CCCC(C)(C)[C@@H]1CC[C@H]1C=Cc2c(cc(C)c(C(=O)O)c2O)O1</smiles><smiles></smiles>

cell systems of $H$. siccans. ${ }^{136}$ It involves (a) formation of trans- $\gamma$-monocyclofarnesol 273 from farnesyl pyrophosphate; (b) coupling with orsellinic acid 67; (c) oxidative conversion of the resulting presiccanochromenic acid 272 to 271, followed by decarboxylation to siccanochromen A $\mathbf{2 6 3}$, and (d) epoxy-olefin type cyclization of $\mathbf{2 6 4}$ to $\mathbf{2 6 2}$. Presumably

267 would be formed by loss of a proton from the same carbocation intermediate involved in formation of 262, and the remaining metabolites would be formed by alternative rearrangements of the epoxide 264 to give the allylic alcohol 265 or the aldehyde $\mathbf{2 7 0}$ followed by reduction to $\mathbf{2 6 6}$ and oxidation to 269.<smiles>[Y]C(=O)OCCC(C)=CCc1c(O)cc(C)c(C(=O)O)c1O</smiles><smiles>Cc1cc(O)c2c(c1)O[C@H]1CC[C@H]3C(C)(C)CCC[C@]3(C)[C@H]1COC2</smiles>

262<smiles>Cc1cc(O)c2c(c1)O[C@H](CC[C@H]1C=CCCC1(C)C)CC2</smiles>

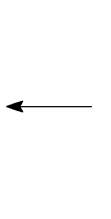<smiles>C=C1CCCC(C)(C)[C@H]1CCC1C=Cc2c(O)cc(C)cc2O1</smiles>

263<smiles>Cc1cc(O)c2c(c1)O[C@]1(C)CC[C@H]3C(C)(C)CCC[C@]3(CO)C1=C2</smiles>

267
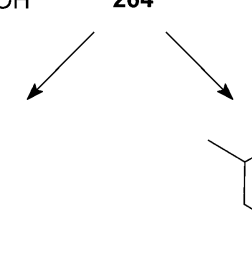

Scheme 15 Proposed biosynthetic pathway for siccanin 262. 
The lipophilic fraction of the acetone extract of fresh specimens of the mushroom Albatrellus ovinus collected in the neighbourhood of Zbiroh in Bohemia (Czechoslovakia) contained as the main components two closely related antibiotically active phenolic compounds, grifolin 274 and neogrifolin 275. ${ }^{137}$ The former had previously been isolated from the fungus Grifola confluens. ${ }^{138}$ Monomethylgrifolin 276, dimethylgrifolin 277 and dimethylneogrifolin $\mathbf{2 7 8}$ were also isolated as minor components of the acetone extract. ${ }^{137}$

Chemical investigation of other Albatrellus species has resulted in a series of grifolin derivatives. Cristatic acid 279, the first example of a grifolin containing a furan ring, was isolated from the fruiting bodies of $A$. cristatus. ${ }^{139}$ Grifolic acid 280 was isolated from an American Albatrellus species. ${ }^{139}$ In addition, gri- folic acid methyl ester $\mathbf{2 8 1}$ and grifolinol $\mathbf{2 8 2}$ were isolated together with $\mathbf{2 7 7}$ and $\mathbf{2 8 3}$ from the methanol extract of the inedible mushroom A. dispansus. ${ }^{140}$ The related fungus Polyporus dispansus produced the three farnesylphenols 283, 284, and 285 . $^{141}$

Grifolinone A $\mathbf{2 8 6}$ and the furanoid dimer grifolinone B 287 were isolated from the methanolic extract of $A$. caeruleoporus with 274 and 275. ${ }^{142}$ The pigments albatrelin 288 and 16hydroxyalbatrelin 289, responsible for the blue color of $A$. flettii, have been isolated and their structure elucidated by spectroscopic methods. ${ }^{143} \mathbf{2 8 8}$ is a dimeric meroterpenoid with a furylbenzoquinone chromophore. In addition, grifolinone C $\mathbf{2 9 0}$, which displays an alternative mode of dimerisation through the aromatic moieties, was obtained from the fruiting bodies of

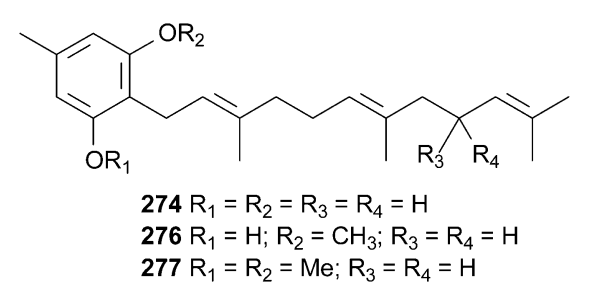

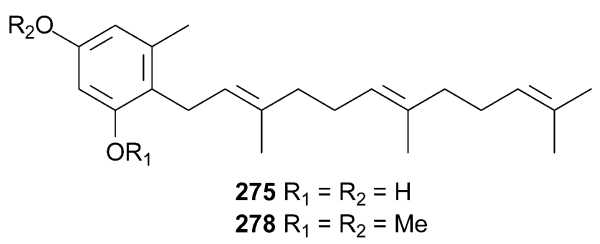<smiles>CC(C)=Cc1cc(CCC/C(C)=C/Cc2c(O)cc(C)c(C(=O)O)c2O)co1</smiles>

279<smiles>[R]OC(=O)c1c(C)cc(O)c(C/C=C(\C)CC/C=C(/C)CCC=C(C)C)c1O</smiles>

$280 \mathrm{R}=\mathrm{H}$ $281 \mathrm{R}=\mathrm{Me}$<smiles>CC(C)=CCCC(C)(O)CCC/C(C)=C/Cc1c(O)cc(C)c(C(=O)O)c1O</smiles>

282<smiles>[R16][R16]#[R][R]#[R][R]([H])=O</smiles><smiles>COc1cc(C)c(C(=O)O)c(O)c1C/C=C(\C)CC/C=C(\C)CCC=C(C)C</smiles><smiles>CC(C)=CC(=O)CC(C)=CCCC(C)=CCc1c(O)cc(C)cc1O</smiles>

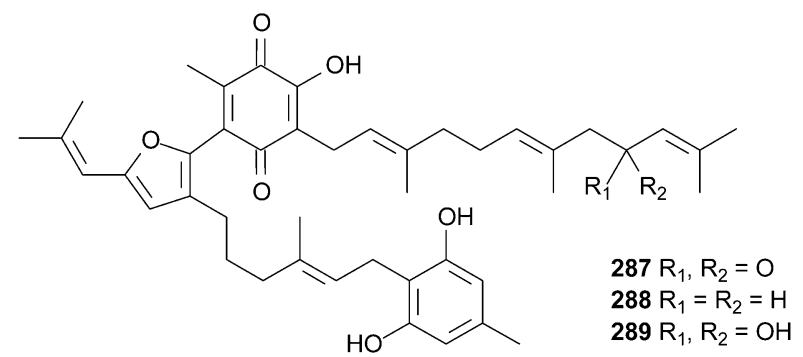<smiles>CC(C)=CCC/C(C)=C/CC/C(C)=C/CC1=C(O)C(=O)C(C)=C(c2c(C)cc(O)c(C/C=C(\C)CCC=C(C)C)c2O)C1=O</smiles><smiles>Cc1cc(O)c(C[C@H]2[C@@H](C)[C@H](O)CC[C@H]3C(C)CCC[C@@]32C)c(O)c1</smiles>

291 
A. confluens, accompanied by $274,275,287$, and $288 .^{144}$ In a further study of $A$. confluens, albaconol 291 was isolated along with grifolin $274 .{ }^{145}$

The compounds 274 and 275 and their derivatives possess interesting biological activities: anti-oxidative activity, ${ }^{146}$ antimicrobial activity, ${ }^{138-140}$ plant growth inhibitory activity, ${ }^{147}$ tyrosinase inhibitory activity, ${ }^{148}$ control of anticholesteremic activity, ${ }^{149}$ activity on human and rat vanilloid receptors, ${ }^{150}$ and cytotoxic activity against Hep G2 human lung carcinoma cells. ${ }^{144}$

During a screening of the fungus Albatrellus ovinus for compounds interacting with mammalian CNS receptors, it was found that ethyl acetate extract displaces the binding of the dopamine $\mathrm{D}_{1}$ receptor subfamily. The active compounds isolated by bioassay-guided fractionation of the crude extract and identified by spectroscopic techniques were ovinol 292, ovinal 293, ilicicolin B 294, scutigeral 295, in addition to 274 and 275. ${ }^{151}$ Asperugin A 296 and B 297 are farnesyloxy-phthalaldehyde metabolites of Aspergillus rugulosus. ${ }^{152,153}$

The antibiotic ascochlorin $\mathbf{2 9 8}$ was obtained as a terpenoid metabolite from Acremonium luzulae. ${ }^{154}$ Recently, ascochlorin analogs were isolated from the insect-pathogenic fungus Verticillium hemipterigenum and were named vertihemipterin A 299 , $4^{\prime}, 5^{\prime}$-dihydro-4'-hydroxyascochlorin 300, $8^{\prime}$-hydroxyascochlorin 301, LL-Z1272 302, 8', $9^{\prime}$-dehydroascochlorin 303, ascofuranone 304 and ascofuranol $\mathbf{3 0 5}{ }^{155}$ With the exception of $\mathbf{3 0 0}$ and $\mathbf{3 0 5}$, all the ascochlorin analogues exhibited significant antitumor and cytotoxic activities. ${ }^{155}$ Compounds 298 and $\mathbf{3 0 3}$ also showed antiviral potency.<smiles>CC(C)=CCC/C(C)=C/CC/C(C)=C/Cc1c(C)cc(O)c(O)c1O</smiles><smiles>CC(C)=CCC/C(C)=C/CC/C(C)=C/Cc1c(O)cc(O)c(C=O)c1C</smiles><smiles>CC(C)=CCC/C(C)=C/CC/C(C)=C/Cc1c(O)cc(C)c(C=O)c1O</smiles>

294<smiles>CC(C)=CCC/C(C)=C/CC/C(C)=C/Cc1c(C)c(C=O)c(O)c(O)c1O</smiles>

295

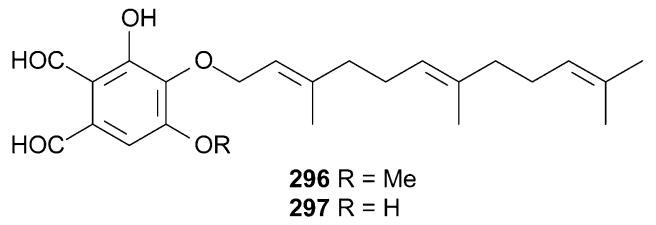<smiles>CC(/C=C/[C@H]1[C@@H](C)CCC(=O)[C@H]1C)=C\Cc1c(O)c(Cl)c(C)c(C=O)c1O</smiles>

298

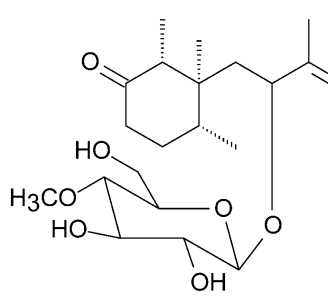<smiles>CCCc1c(O)c(Cl)c(C)c(C=O)c1O</smiles>

299<smiles>CC(=O)OC1CC(=O)[C@H](C)[C@@H](/C=C/C(C)=C/Cc2c(O)c(Cl)c(C)c(C=O)c2O)[C@@H]1C</smiles><smiles>CC(/C=C/[C@@H]1[C@H](C)C(=O)C=C[C@@H]1C)=C\Cc1c(O)c(Cl)c(C)c(C=O)c1O</smiles><smiles>CC(/C=C/[C@H]1[C@@H](C)C(=O)C[C@@H](O)[C@@H]1C)=C\Cc1c(O)c(Cl)c(C)c(C=O)c1O</smiles>$$
302
$$<smiles>C/C(=C\Cc1c(O)c(Cl)c(C)c(C=O)c1O)[C@@H](O)C[C@H]1[C@@H](C)CCC(=O)[C@H]1C</smiles>

300<smiles>CC(=CCc1c(O)c(Cl)c(C)c(C=O)c1O)CCC=C(C)[C@H]1CC(=O)C(C)(C)O1</smiles><smiles>CC(=CCc1c(O)c(Cl)c(C)c(C=O)c1O)CCC=C(C)[C@@H]1CC(O)C(C)(C)O1</smiles> 


\section{Meroterpenoids containing other polyketide- terpenoid moieties}

UV-guided fractionation of an extract of Penicillium hesseltinei, isolated from the cheek pouch of a kangaroo rat (Dipodormys spectabilis), yielded hesseltin A 306, a compound of mixed polyketide-terpenoid origin (pentaketide-farnesyl moiety). ${ }^{156}$ This compound exhibited antiviral activity toward HSV-1.

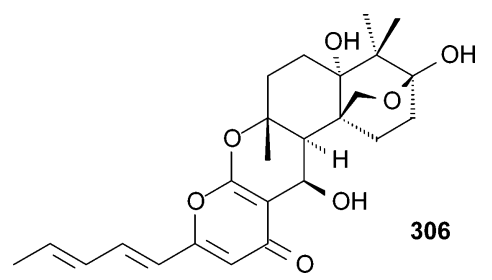

The two yellow pigments cochlioquinones A $\mathbf{3 0 7}$ (also named as luteoleersin) and B 308, produced in submerged culture by Cochliobolus miyabeanus (Helminthosporium oryzae), are derived from a hexaketide-farnesyl intermediate. Their structures were determined on the basis of IR, UV, NMR spectra and by chemical correlations. ${ }^{157,158}$ The search for inhibitors of CCR5 led to the recent isolation of three active cochlioquinones from Bipolaris brizae (Nisikado) Shoem, namely 17-methoxycochlioquinone A 309, isocochlioquinone A 310 and the known 307. ${ }^{159}$ In addition, two active epi-cochlioquinone compounds, 11-O-methyl-epi-cochliquinone A 311 and epi-cochlioquinone A 312, were isolated from Stachybotrys chartarum. These compounds were found to compete effectively with MIP-1 $\alpha$ for binding to human CCR5. ${ }^{159}$ Moreover, 312 has also been isolated from the fermentation broth of Stachybotrys bisbyi SANK17777 and exhibited an acyl-CoA:cholesterol acyltransferase (ACAT) inhibitor activity. ${ }^{\mathbf{1 6 0}}$

Another structurally related compound alboleersin (14,17didehydro-14,17-dideoxo-14,17-dihydroxycochlioquinone A) 313 was isolated in addition to $\mathbf{3 0 7}$, from the plant pathogen fungus Helminthosporium leersii. ${ }^{161}$

Ten phytotoxic compounds were obtained from a culture of Bipolaris cynodonthis, a leaf-blight-causing fungal pathogen of gramineous plants. The purified compounds were identified and named as cochlioquinones C 314, D 315 and E 316, isochlioquinone C 317, cochlioquinols I 318, II 319 and III 320, in addition to the known cochlioquinones 307,308 and $310 .{ }^{162}$

Stemphone 321, a cytotoxic and antibacterial yellow pigment, is produced by Stemphylium sarcinaeforme. ${ }^{163}$ Its structure was determined from chemical and spectral data and by X-ray crystallographic analysis. ${ }^{164}$ Stemphones B 322 and C 323 were isolated along with $\mathbf{3 1 5}$ from the fermentation broth of Aspergillus sp. FKI-2136. Stemphone C showed potent imipenem activity against methicilin-resistant Staphylococcus aureus (MRSA). ${ }^{\mathbf{1 6 5}}$

Previous studies have established the mixed biosynthesis of cochlioquinones $\mathbf{3 0 7}$ and 308, through the introduction of a farnesyl unit onto an aromatic precursor whose secondary methyl groups are derived from methionine. ${ }^{166}$ Experiments using ${ }^{18} \mathrm{O}_{2}$ as isotopic tracer and mass spectrometry showed that the two oxygen atoms of the 2-(2-hydroxypropyl)tetrahydropyran system are derived from two different oxygen molecules at separate steps on the biosynthetic pathway, suggesting the intermediary of two epoxides (Scheme 16). ${ }^{167}$ Further studies with ${ }^{13} \mathrm{C}$ - and ${ }^{14} \mathrm{C}$-labelled compounds, ${ }^{18} \mathrm{O}_{2},{ }^{13} \mathrm{C} \mathrm{NMR}$ spectroscopy and mass spectrometry indicated a possible biosynthetic sequence, namely prenylation of an acetogeninderived aromatic nucleus $\mathbf{3 2 4}$ leading to intermediate $\mathbf{3 2 5}$, decarboxylation-hydroxylation to $\mathbf{3 2 6}$ and then cyclization of the farnesyl chain to cochlioquinone B 308 (Scheme 16). ${ }^{168}$ Thus the three rings of the terpenoid moiety seem to be biosynthesized via a bis-epoxide 327. It was proposed that opening of these epoxides is promoted by the cyclization process which starts from attack of the phenolic hydroxyl-group to lead to $327 .{ }^{168}$

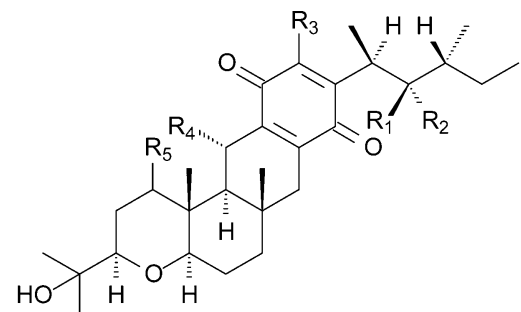

$307 R_{1}=H ; R_{2}=O A c ; R_{3}=H ; R_{4}=O H ; R_{5}=H$
$308 R_{1}=R_{2}=O ; R_{3}=R_{4}=R_{5}=H$
$309 R_{1}=H ; R_{2}=O A c ; R_{3}=M e ; R_{4}=O H ; R_{5}=H$
$314 R_{1}=R_{2}=O ; R_{3}=H ; R_{4}=O H ; R_{5}=H$
$316 R_{1}=R_{2}=O ; R_{3}=R_{4}=H ; R_{5}=O H$

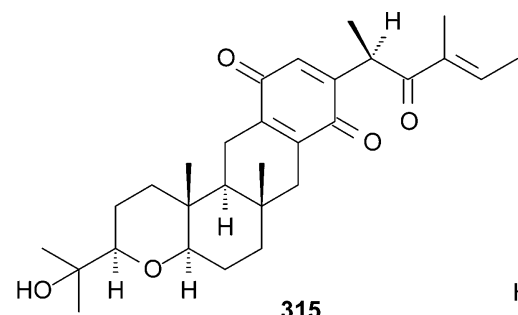

315

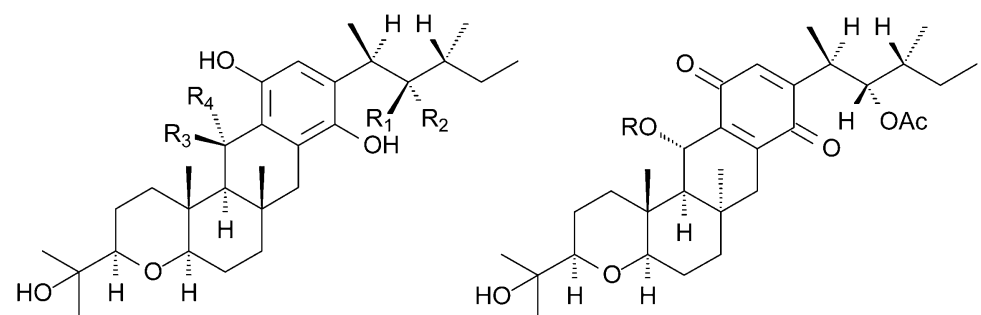

$310 R_{1}=H ; R_{2}=O A C ; R_{3}=R_{4}=0$

$313 \mathrm{R}_{1}=\mathrm{H} ; \mathrm{R}_{2}=\mathrm{OAc} ; \mathrm{R}_{3}=\mathrm{H} ; \mathrm{R}_{4}=\mathrm{OH}$

$311 \mathrm{R}=\mathrm{Me}$

$312 \mathrm{R}=\mathrm{H}$

$317 \mathrm{R}_{1}=\mathrm{R}_{2}=\mathrm{O} ; \mathrm{R}_{3}=\mathrm{R}_{4}=\mathrm{O}$

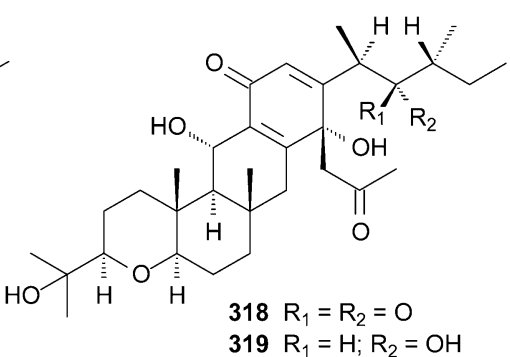




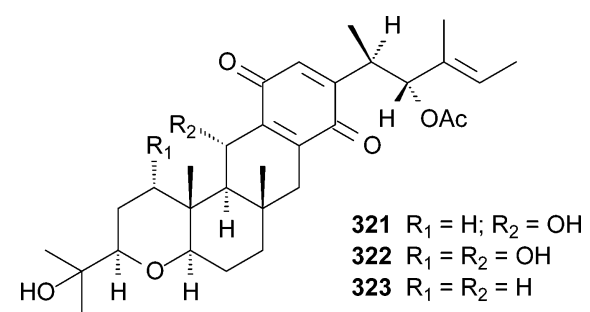

However, an alternative to the literature proposal (which is in line with cyclizations of triterpenes, which are carbocationmediated and proceed in a step-wise sequence) would be as follows (Scheme 17). The process is initiated by protonation of the distal epoxide group in $\mathbf{3 2 7}$, allow opening of this ring to generate a secondary carbocation (anti-Markovnikov), which is assisted by the other epoxide producing the preferred tertiary carbocation, suitably placed to allow electrophilic addition to a double bond, formation of a six-membered ring and production of a new tertiary carbocation (Markovnikov addition), which is finally quenched by the phenolic hydroxyl group.

Viridicatumtoxin 329, a mycotoxin from Penicillium viridicatum, ${ }^{169}$ was shown to be formed by a mixed polyketide-terpenoid (nonaketide backbone) biosynthetic pathway through incorporation of labelled precursors. ${ }^{170}$ The spirocyclic ring system in 329 is presumably derived from geranyl pyrophosphate. ${ }^{171}$<smiles>COc1cc(O)c2c(O)c3c4c(c2c1[C@]1(C3)C(C)=CCCC1(C)C)C(=O)[C@@]1(O)CC(C(N)=O)=C(O)C[C@]1(O)[C@@H]4O</smiles>

329

\section{Meroterpenoids containing non-polyketide- terpenoid moieties}

The meroterpenoid montadial A $\mathbf{3 3 0}$ has been isolated from the polypore Bondarzewia montana, a rare white-rot fungus that grows at the base of Abies trees and other conifers. ${ }^{172}$ It exhibits cytotoxic effects against L1210 tumor cells (lymphocytic leukaemia of rice) and a weak phytotoxic effect against Setaria italica.<smiles>C/C(C=O)=C\Cc1cc(C=O)cc(O)c1O</smiles>

330

A group of structurally related 2,5-dihydroxy-1,4-benzoquinones with oligoprenyl side chains has been isolated from several

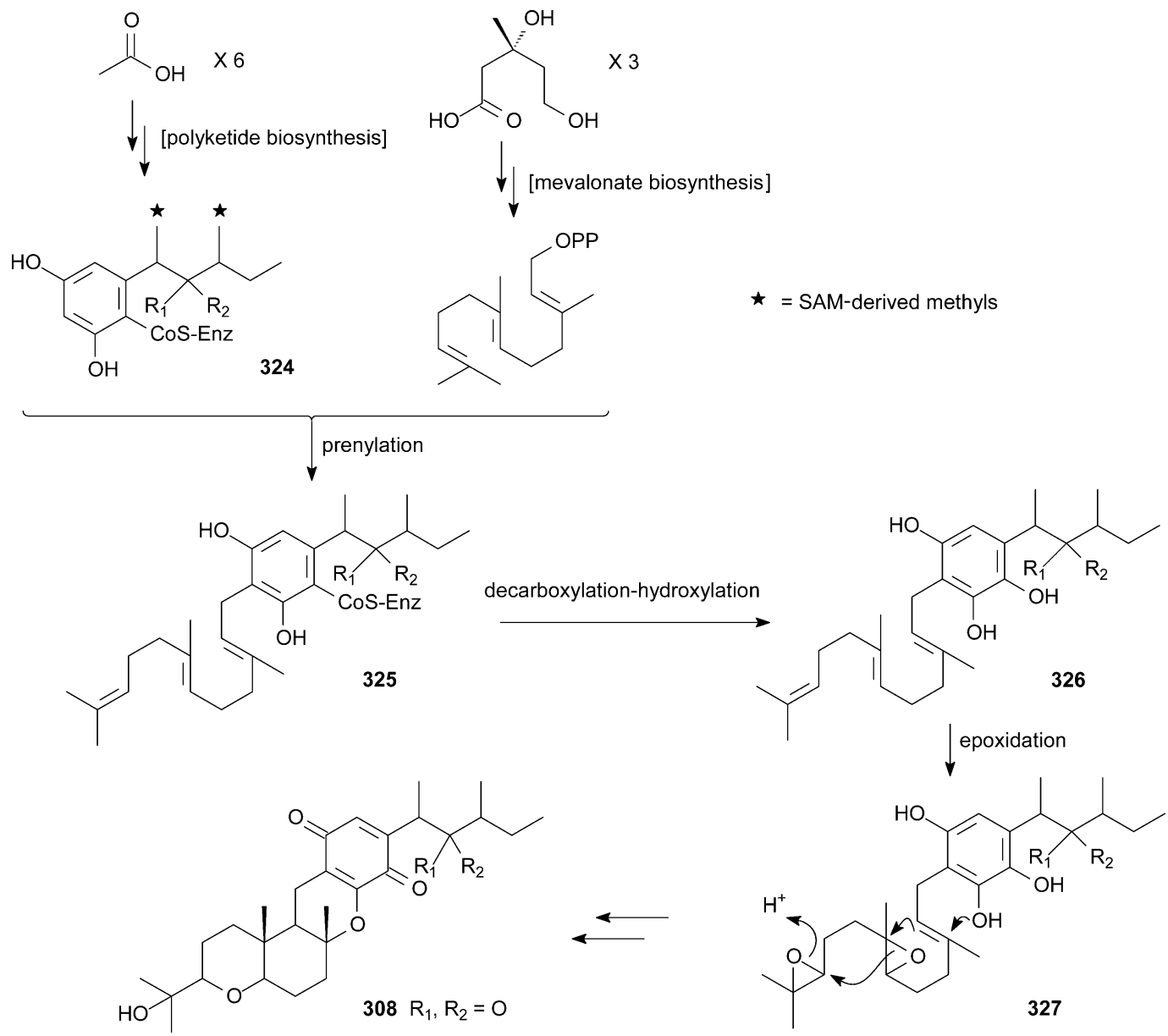

Scheme 16 Possible biosynthetic sequence for cochlioquinones and derivatives (adapted from Canonica et al. ${ }^{166-168}$ ). 


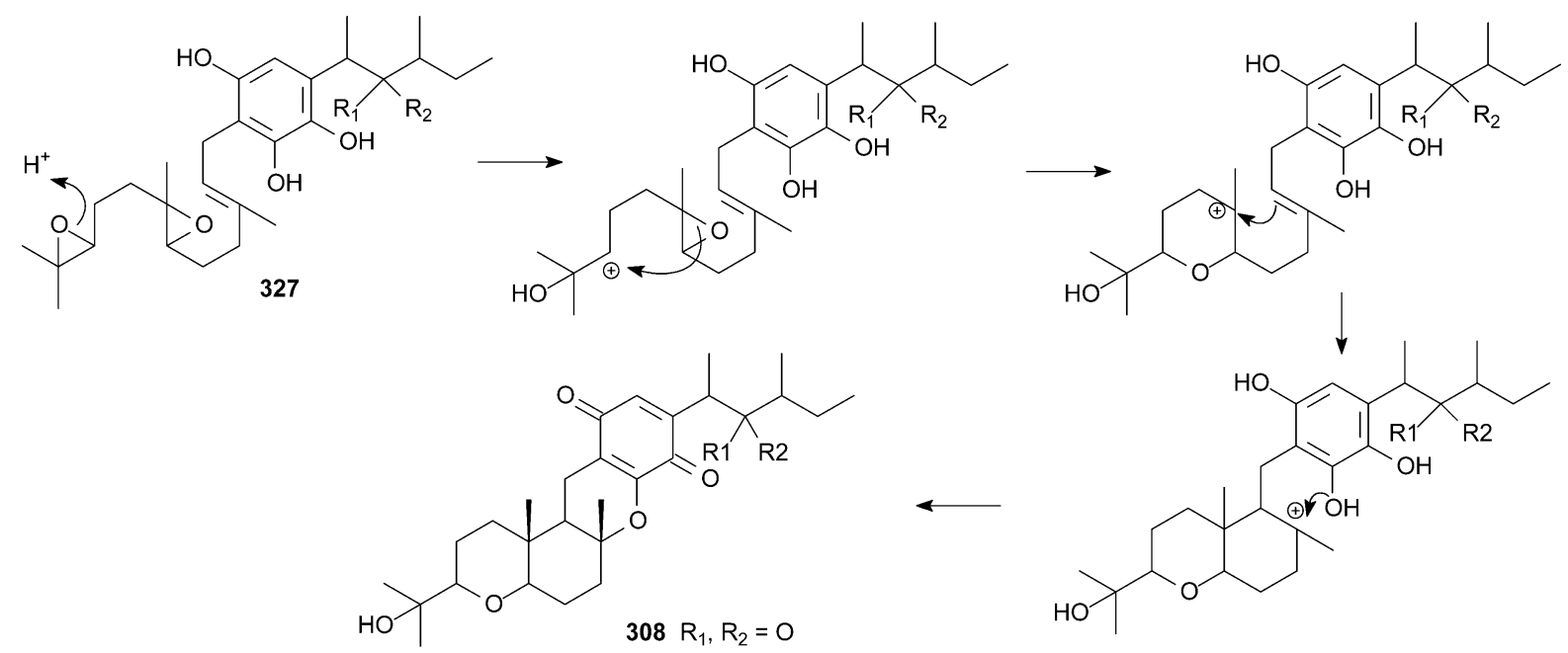

Scheme 17 Alternative proposal to the literature biosynthetic sequence to the cochlioquinones and derivatives.

basidiomycetes belonging to the order Boletales. ${ }^{173}$ The pigment from Chroogomphus helveticus and C. rutilus was identified as helveticone (2,4-dihydroxy-3-farnesyl-1,4-benzoquinone) 331, ${ }^{174}$ also named boviquinone-3. ${ }^{174} \mathrm{~A}$ related compound boviquinone4332 was produced by Boletus (Suillus) bovines. ${ }^{175}$ A key step in the biosynthesis of the fungal meroterpenoids $\mathbf{3 3 1}$ and $\mathbf{3 3 2}$ is the prenylation of 3,4-dihydroxybenzoic acid 333. Biosynthetic investigations allowed the proposal that in fruiting-bodies of S. bovines $\mathbf{3 3 2}$ is formed by geranylgeranylation of $\mathbf{3 3 3}$ at C-2, whereas in C. rutilus the farnesyl side chain of $\mathbf{3 3 1}$ is introduced at C-5 (Scheme 18). ${ }^{173}$

Tridentoquinone 336, a red ansaquinone pigment, was isolated from the fruiting body of the fungus Suillus tridentinus. ${ }^{176}$ Its structure, a [13](3,6)-benzofuranophane, was assigned from chemical evidence and X-ray crystal structure analysis. Bolegrevilol 337 was obtained from the edible mushroom S. grevillei. ${ }^{177}$ This compound is a lipid peroxidation inhibitor. Studies on the structure and biosynthesis of $\mathbf{3 3 6}$ led to the isolation of tridentorubin $\mathbf{3 3 8}$ and deoxytridentoquinone 339. ${ }^{178}$

Feeding experiments with $\left[1-{ }^{13} \mathrm{C}\right]$-labeled 4-hydroxybenzoic acid 340 and 3,4-dihydroxybenzoic acid $\mathbf{3 3 3}$ proved the incorporation of these precursors into metabolites 336-338 during their biosynthesis in the fruiting bodies of $S$. tridentinus (Scheme 19). This excludes the possibility that boviquinone-4 332 is a precursor of $\mathbf{3 3 6} .{ }^{178}$ The labelled carbonyl group in $\mathbf{3 3 6}$ corresponds to C-1 of 3,4-dihydroxybenzoic acid 333, suggesting 6-(geranylgeranyl)benzene-1,2,4-triol $\mathbf{3 4 1}$ as possible intermediate. This triol could then either be acetylated to yield bolegrevilol 337 or oxidized to hydroxybenzoquinone 342, the immediate precursor of deoxytridentoquinone 339. The latter could be formed by oxidative cycloaddition of the hydroxyquinone moiety of $\mathbf{3 4 1}$ to the terminal double bond of the side chain, probably by a radical mechanism. Hydroxylation of ansaquinone 339 would then yield tridentoquinone 336. The labelling pattern observed for tridentorubin $\mathbf{3 3 8}$ can be explained by addition of $\mathbf{3 4 2}$ to $\mathbf{3 3 6}$.

A number of terpenoid compounds named tricycloalternarenes (TCAs) were isolated from the culture of the phytopathogenic fungus Alternaria alternata, which originated from Brassica sinensis. ${ }^{179,180}$ Their structures were elucidated by spectroscopic methods, and were identified as TCAs 1a-8a 343-350, 11a 351, 1b-7b 352-358, and 9b-11b 359-361. These metabolites are closely related to the minor ACTG-toxins (Alternaria citri tangerine-toxins) which damage leaves of sensitive varieties of Citrus reticulata ${ }^{180}$ Moreover, these compounds are non-specific toxins. ${ }^{180}$ Precursors of TCAs were also found in a methanol extract obtained from the lyophilized culture filtrate of A. alternata. They were named bicycloalternarenes (BCAs) 1-11 362-372. ${ }^{181}$

Incorporation of $\left[2-{ }^{13} \mathrm{C}\right]$-mevalonate, $\left[1-{ }^{13} \mathrm{C}\right]$-acetate and $\left[1-{ }^{13} \mathrm{C}\right]$-glucose showed that BCAs are biosynthesized by the classic mevalonate pathway. ${ }^{182}$ The polyketide pathway does not participate in the biosynthesis of BCAs because there is no

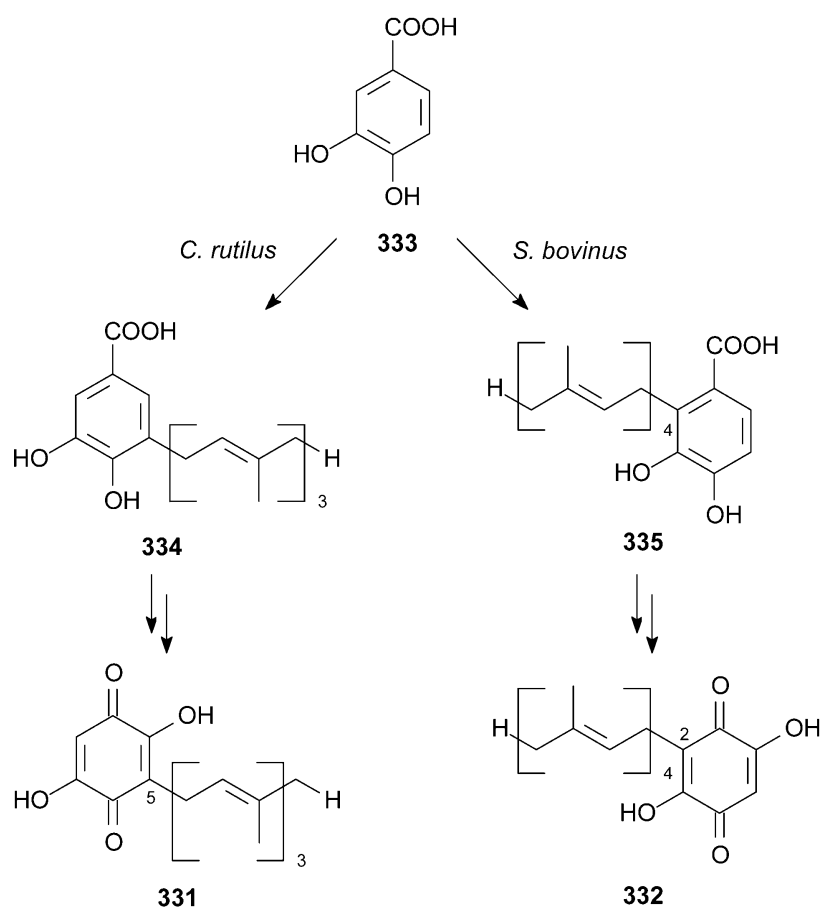

Scheme 18 Proposed pathways for the biosynthesis of boviquinone-3 334 and -4335. 


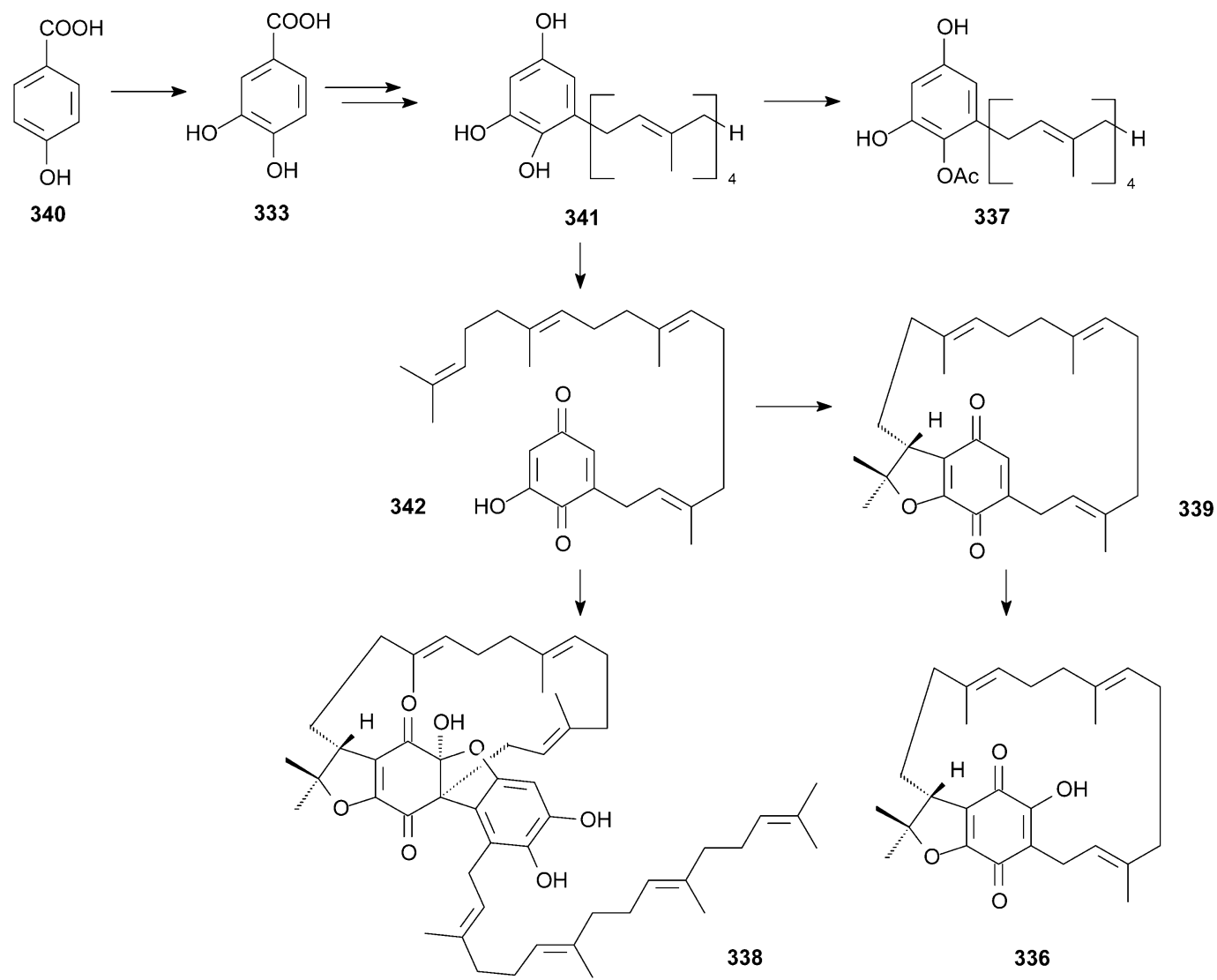

Scheme 19 Proposed pathways for the biosynthesis of tridentoquinone $\mathbf{3 3 6}$ and related compounds.

incorporation of $\left[{ }^{13} \mathrm{C}\right]$-acetate into the $\mathrm{C}$-ring of these compounds. The labelling pattern in this nonterpenoid part of BCAs after feeding with $\left[1-{ }^{13} \mathrm{C}\right]$-glucose and $\left[\mathrm{U}_{-}{ }^{13} \mathrm{C}_{6}\right]$-glucose, respectively, allows the assumption that metabolites of the shikimate pathways are involved.

A hypothetical pathway to the BCAs is summarized in Scheme $20{ }^{182}$ Tetrose and phosphoenolpyruvate react in the first step of the skikimate pathway to 3-deoxy-D-arabino-heptulosonic acid 7-phosphate (DAHP) 373, subsequently giving 3dehydroquinic acid 374, which after oxidation, reduction and dehydration processes gives the intermediate 375 . The next step involves the alkylation of precursor 375 by sesquiterpenoid 376 to give the intermediate 377 . Further modification leads to BCA and TCA compounds. The keto-enol tautomerism of the 1,3diketone structure in the six-membered ring of BCAs allied to the free rotation of this ring leads to the different structures and labelling patterns observed in the hydroxycyclohexenone ring of the TCAs. ${ }^{182}$

\section{Miscellaneous meroterpenoids}

Screening of fungi as sources of bioactive metabolites has led to the discovery of natural products with insecticidal activities. Most of these are indole diterpenoids (despite them being<smiles>O=C(O)CC(O)C(O)C(O)COP(=O)(O)O</smiles>

373<smiles>O=C1CC(O)(C(=O)O)CC(O)C1O</smiles>

374

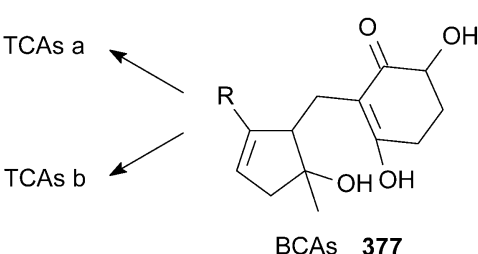
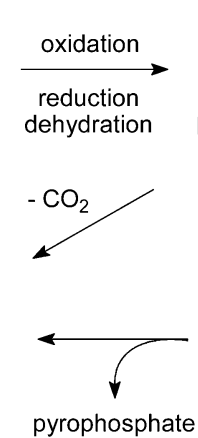

pyrophosphate<smiles>O=C(O)C1(O)CCC(O)=CC1=O</smiles><smiles>[R]C1=CCC(C)(O)C1COP</smiles>

376

Scheme 20 Hypothetical pathways to bicycloalternarenes (BCAs) and tricycloalternarenes (TCAs). 
<smiles>[R]C1CC([R])C2=C(CC3C(C(C)CCCC(C)CO)=CCC3(C)O2)C1=O</smiles>

$343 \mathrm{R}_{1}=\mathrm{OH}, \mathrm{R}_{2}=\mathrm{H}$

$351 \mathrm{R}_{1}=\mathrm{OMe}, \mathrm{R}_{2}=\mathrm{H}$

$352 R_{1}=H, R_{2}=O H$

$361 R_{1}=H, R_{2}=O M e$<smiles>[R3]C(C)=CCCC(C)C1=CCC2(C)OC3=C(CC12)C(=O)C([R])CC3[R]</smiles>

$344 \mathrm{R}_{1}=\mathrm{OH}, \mathrm{R}_{2}=\mathrm{H}, \mathrm{R}_{3}=\mathrm{CH}_{2} \mathrm{OH}$

$345 \mathrm{R}_{1}=\mathrm{OH}, \mathrm{R}_{2}=\mathrm{H}, \mathrm{R}_{3}=\mathrm{Me}$

$346 \mathrm{R}_{1}=\mathrm{OMe}, \mathrm{R}_{2}=\mathrm{H}, \mathrm{R}_{3}=\mathrm{Me}$

$353 \mathrm{R}_{1}=\mathrm{H}, \mathrm{R}_{2}=\mathrm{OH}, \mathrm{R}_{3}=\mathrm{CH}_{2} \mathrm{OH}$

$354 R_{1}=H, R_{2}=O H, R_{3}=M e$

$355 \mathrm{R}_{1}=\mathrm{H}, \mathrm{R}_{2}=\mathrm{OMe}, \mathrm{R}_{3}=\mathrm{Me}$

$360 \mathrm{R}_{1}=\mathrm{H}, \mathrm{R}_{2}=\mathrm{OMe}, \mathrm{R}_{3}=\mathrm{CH}_{2} \mathrm{OH}$<smiles>[R3]C(C)=CC/C=C(/C)[C@H]1CC[C@]2(C)OC3=C(C[C@H]12)C(=O)C([R2])CC3[R]</smiles>

$347 \mathrm{R}_{1}=\mathrm{OMe}, \mathrm{R}_{2}=\mathrm{H}, \mathrm{R}_{3}=\mathrm{Me}$

$350 \mathrm{R}_{1}=\mathrm{OH}, \mathrm{R}_{2}=\mathrm{H}, \mathrm{R}_{3}=\mathrm{CH}_{2} \mathrm{OH}$

$356 R_{1}=H, R_{2}=O M e, R_{3}=M e$

$359 \mathrm{R}_{1}=\mathrm{H}, \mathrm{R}_{2}=\mathrm{OH}, \mathrm{R}_{3}=\mathrm{Me}$<smiles>[R]C1CC([R])C2=C(CC3C(C(C)CCC(O)C(C)(C)O)=CCC3(C)O2)C1=O</smiles>

$348 \mathrm{R}_{1}=\mathrm{OH}, \mathrm{R}_{2}=\mathrm{H}$

$349 \mathrm{R}_{1}=\mathrm{OMe}, \mathrm{R}_{2}=\mathrm{H}$

$357 \mathrm{R}_{1}=\mathrm{H}, \mathrm{R}_{2}=\mathrm{OH}$

$358 R_{1}=H, R_{2}=O M e$<smiles>[R]C1CCC(=O)C(CC2C(C(C)CCCC(C)CO)=CCC2(C)O)=C1O</smiles>

$362 \mathrm{R}=\mathrm{OH}$

$372 \mathrm{R}=\mathrm{OMe}$<smiles>[R]C(C)=CCCC(C)C1=CCC(C)(O)C1CC1=C(O)C([R7])CCC1=O</smiles>

$363 \mathrm{R}_{1}=\mathrm{OH}, \mathrm{R}_{2}=\mathrm{CH}_{2} \mathrm{OH}$

$364 \mathrm{R}_{1}=\mathrm{OH}, \mathrm{R}_{2}=\mathrm{Me}$

$365 \mathrm{R}_{1}=\mathrm{OMe}, \mathrm{R}_{2}=\mathrm{Me}$

$371 \mathrm{R}_{1}=\mathrm{OMe}, \mathrm{R}_{2}=\mathrm{CH}_{2} \mathrm{OH}$<smiles>[R]C(C)=CC/C=C(/C)[C@H]1CC[C@](C)(O)[C@H]1C[C@H]1C(=O)CCC([R1])[C@H]1O</smiles>

$366 \mathrm{R}_{1}=\mathrm{OMe}, \mathrm{R}_{2}=\mathrm{Me}$

$369 \mathrm{R}_{1}=\mathrm{OH}, \mathrm{R}_{2}=\mathrm{CH}_{2} \mathrm{OH}$

$370 \mathrm{R}_{1}=\mathrm{OH}, \mathrm{R}_{2}=\mathrm{Me}$<smiles>[R]C1CCC(=O)C(CC2C(C(C)CCC(O)C(C)(C)O)=CCC2(C)O)C1O</smiles>

$367 \mathrm{R}=\mathrm{OH}$

$368 \mathrm{R}=\mathrm{OMe}$ classified as such previously, they can also be regarded as having a terpenoid-nonpolyketide origin). Several isolates of Aspergillus spp. are known for their production of these compounds as major components of their sclerotia (key survival structures).
From the cultures of sclerotia of $A$. flavus were found aflavinine $378,{ }^{183} 20,25$-dihydroxyaflavinine $379,{ }^{184,185}$ 2-hydroxyaflavinine 380, 14-hydroxy-10,23-dihydro-24,25-dehydroaflavinine $\mathbf{3 8 1}$, 10,11-dihydro-11,12-dehydro-20-hydroxyaflavinine $\mathbf{3 8 2}^{\mathbf{1 8 5}}$ and

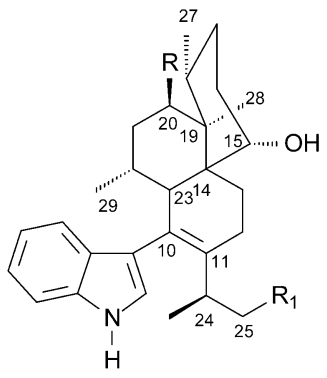

$378 \mathrm{R}=\mathrm{R}_{1}=\mathrm{H}$

$379 \mathrm{R}=\mathrm{R}_{1}=\mathrm{OH}$

$380 \mathrm{R}=\mathrm{OH}, \mathrm{R}_{1}=\mathrm{H}$

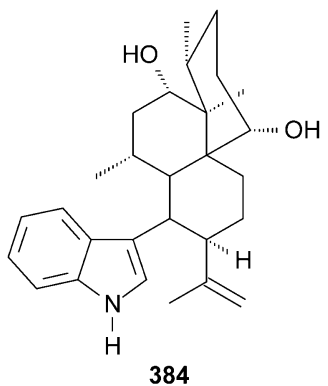

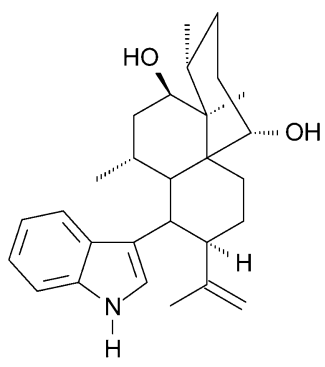

381

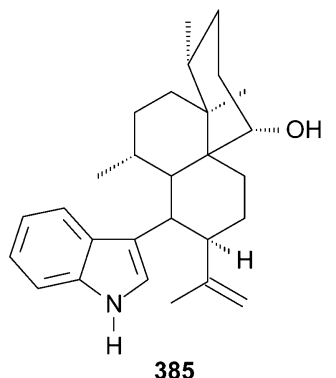<smiles>CC(C)C1=CCC23CCCCC(CCC2O)C3C1c1c[nH]c2ccccc12</smiles>

382

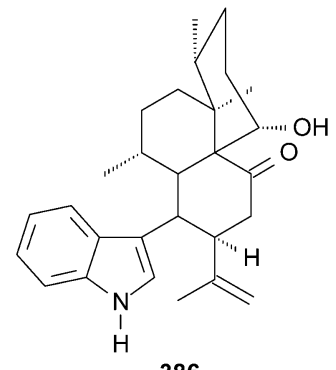

386

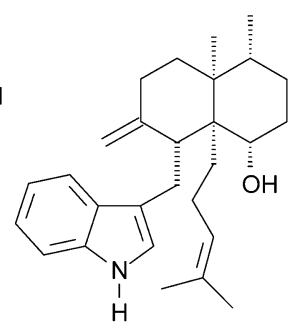

383 
<smiles>CCCCC(O)C12CCc3c(C)cc4[nH]c5ccccc5c4c3C1(CCC)CC(O)CC2O</smiles>

388

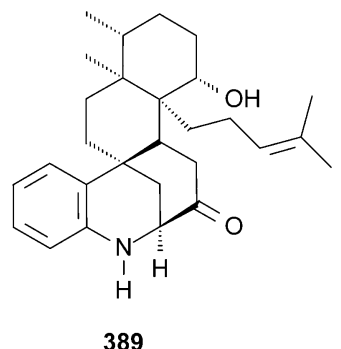

389<smiles>[R]c1ccc2c(C[C@]3(C)[C@@H](C)CC[C@]4(C)[C@@H]5CCC(=O)[C@H](C)[C@@]5(C)CC[C@@H]43)c[nH]c2c1</smiles>

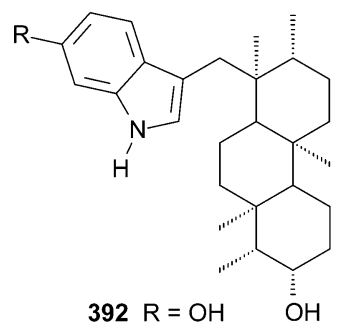

$393 \mathrm{R}=\mathrm{H}$

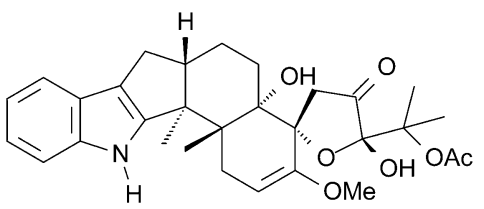

394<smiles>CC(C)C1=CCC23CCC(C)C(C)(Cc4c[nH]c5ccccc45)C2CCC(O)C13C</smiles><smiles>CC(C)=C1CCC2(C)C(O)CCC3C(C)CCCC3(Cc3c[nH]c4ccccc34)C12C</smiles>

aflavazole 388. ${ }^{186}$ Nominine $\mathbf{3 8 3}^{187}$ and aspernominine $\mathbf{3 8 9 ^ { 1 8 8 }}$ were found in cultures of Aspergillus nomius. The related aflavinins 14-epi-14-hydroxy-10,23-dihydro-24,25-dehydroaflavinine 384, 10,23-dihydro-24,25-dehydroaflavinine 385, 10,23-dihydro24,25-dehydro-21-oxo-aflavinine $\mathbf{3 8 6},{ }^{\mathbf{1 8 9}}$ and $\mathbf{3 8} 7^{\mathbf{1 9 0}}$ were isolated from Aspergillus tubingens, while radarins A-D 390-393 were found in sclerotia of Aspergillus sulfureus. ${ }^{191}$ In addition to their insecticide acitivities, compounds 389-393 also show cytotoxicity toward human solid tumor cell lines. ${ }^{\mathbf{1 8 8 , 1 9 1}}$

A further five anti-insect indole diterpenoids, thiersinines A-B 394-395 ${ }^{192}$ and thiersindoles A-C 396-398, ${ }^{193}$ were isolated from organic extracts of Penicillium thiersii. They are biosynthetically related to aflavinines. In addition, tubingensin A 399, an antiviral and antiinsectan carbazole alkaloid biosynthetically related to the aflavinines was isolated from sclerotia of Aspergillus tubingensis. ${ }^{194}$<smiles>CC(=O)OC(C)(C)C1(O)O[C@]2(CC(=O)CCC3(C)[C@@H]4c5[nH]c6ccccc6c5C[C@@H]4CCC32O)C1=O</smiles>

395<smiles>CC(C)=CCCC1(C)C2=C(CCC1O)C(C)(Cc1c[nH]c3ccccc13)C(C)CC2</smiles><smiles>CC(C)=CCCC12c3cc4c(cc3CCC1(C)C(C)CCC2O)[nH]c1ccccc14</smiles>

Finally, three chromogenic meroterpenoids, ochroleucin A1 400, A2 401 and B 402, were obtained from the mushrooms Russula ochroleuca and $R$. viscida. ${ }^{195}$

\section{Conclusions}

In this review, the structures of 333 fungal meroterpenoids have been reported, as well as the biosynthetic pathways which led to the production of the majority of these compounds. As discussed in each section, meroterpenoids show an enormous structural diversity, arising from successive modifications such as alkylation, condensation, oxidation and reduction. Despite of this, they can be classified according to their fundamental backbone as polyketide-terpenoid and non-polyketide-terpenoid. What is most notable is that most of the fungal meroterpenoids described here $(81 \%)$ are polyketide-derived, as shown in Fig. 2. Moreover,<smiles>C=C(C)C#CC1=CC(=O)C2(C1)C(=O)Oc1c(C#CC(=C)C)cc(O)c(C(=O)O)c12</smiles><smiles>C=C(C)C#CC1=CC(=O)O/C1=C1/C(=O)Oc2c(C#CC(=C)C)cc(O)c(C)c21</smiles><smiles>C=C(C)C#CC1=CC(=O)C2(O)OCc3c(OC)cc(C#CC(=C)C)c(OC)c3[C@]12O</smiles> 


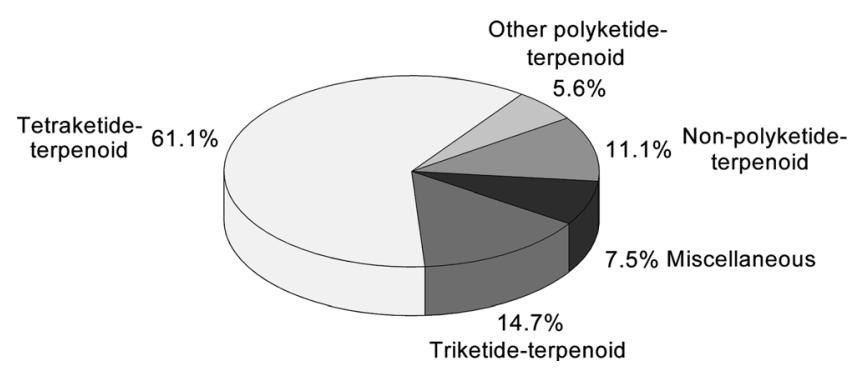

Fig. 2 Distribution of fungal meroterpenoids into categories according to their fundamental backbone.

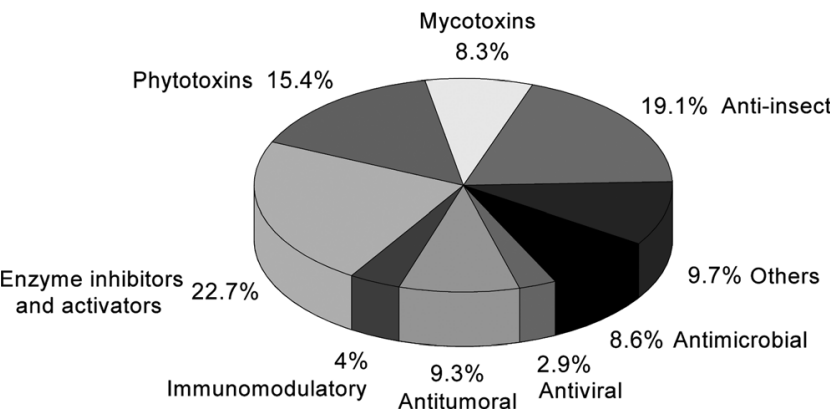

Fig. 3 Distribution of biological activities of fungal meroterpenoids.

within this group the tetraketide-terpenoid class is predominant, and comprises about $61 \%$ of all meroterpenoids.

A second point discussed in this review is the wide range of biological activities described for these compounds. Fig. 3 shows the distribution of biological activities of these compounds, grouped into nine main areas: antimicrobial (including antibacterial and antifungal), antiviral, antitumoral, immunomodulatory (and immunosuppressant), enzyme inhibitors and activators, phytotoxins (and agrochemicals), mycotoxins, antiinsect (including antifeeding and larvicidal) and others (receptors, nerve growth factor, and plasminogen activation).

The data reported here support the current views on searching for new therapeutics through biological screening programmes. The ability of microorganisms to produce natural products with diverse structures and biological properties should prompt us to further explore their extracts.

\section{Acknowledgements}

The authors would like to thank Dr Frederico Guare for the helpful discussions during the writing of this review and Dr Marcos Malta for the proof-reading.

\section{References}

1 J. W. Cornforth, Chem. Br., 1968, 4, 102.

2 IUPAC Compendium of Chemical Terminology, 2nd edn, 1997.

3 R. Croteau, T. N. Kutchan and N. G. Lewis, in Biochemistry \& Molecular Biology of Plants, ed. B. Buchanan, W. Gruissem and R. Jones, American Society of Plant Physiologists, 2000, p. 1250.

4 L. Ge, J. W. H. Yong, S. N. Tan, X. H. Yang and E.S.O., J. Chromatogr., A, 2004, 1048, 119.

5 G. Sabitha, R. Swapna, R. Satheesh Babu and J. S. Yadav, Tetrahedron Lett., 2005, 46, 6145.
6 G. Brader, M. Bacher, O. Hofer and H. Greger, Phytochemistry, 1997, 45, 1207.

7 C. H. Ashton, Br. J. Psychiatry, 2001, 178, 101.

8 C. N. Backhouse, C. L. Delporte, R. E. Negrete, S. Erazo, A. Zuniga, A. Pinto and B. K. Cassels, J. Ethnopharmacol., 2001, 78, 27.

9 B. Sontag, N. Arnold, W. Steglich and T. Anke, J. Nat. Prod., 1999, 62, 1425.

10 A. J. Birch, Science, 1967, 156, 202.

11 T. J. Simpson, Chem. Ind., 1995, 407.

12 D. O'Hagan, Nat. Prod. Rep., 1995, 12, 1.

13 T. J. Simpson, Top. Curr. Chem., 1998, 195, 1.

14 J. Staunton and K. J. Weissman, Nat. Prod. Rep., 2001, 18, 380.

15 R. J. Cox, Org. Biomol. Chem., 2007, 5, 2010.

16 F. A. Macías, R. M. Varela, A. M. Simonet, H. G. Cutler, S. J. Cutler, S. A. Ross, D. C. Dunbar, F. M. Dugan and R. A. Hill, Tetrahedron Lett., 2000, 41, 2683.

17 F. A. Macías, R. M. Varela, A. M. Simonet, H. G. Cutler, S. J. Cutler, F. M. Dugan and R. A. Hill, J. Org. Chem., 2000, 65, 9039.

18 T. Sassa, H. Sato and H. Kajiura, Tetrahedron Lett., 1986, 27, 2121.

19 K. H. Ling, C.-K. Yang and F.-T. Peng, Appl. Environ. Microbiol., 1979, 37, 355.

20 K. H. Ling, H. H. Liou, C.-H. Yang and C.-K. Yang, Appl. Environ. Microbiol., 1984, 47, 98.

21 F.-C. Peng, J. Nat. Prod., 1997, 60, 842.

22 S.-S. Lee, J. Nat. Prod., 1992, 55, 251.

23 S. Omura, F. Kuno, K. Otoguro, T. Sunazuka, K. Shiomi, R. Masuma and Y. Iwai, J. Antibiot., 1995, 48, 745.

24 F. Kuno, K. Otoguro, K. Shiomi, Y. Iwai and S. Omura, J. Antibiot., 1996, 49, 742.

25 F. Kuno, K. Shiomi, K. Otoguro, T. Sunazuka and S. Omura, $J$. Antibiot., 1996, 49, 748.

26 K. Otoguro, K. Shiomi, Y. Yamaguchi, N. Arai, T. Sunazuka, R. Masuma, Y. Iwai and S. Omura, J. Antibiot., 2000, 53, 50.

27 M. Handa, T. Sunazuka, K. Nagai, R. Kimura, K. Otoguro, Y. Harigaya and S. Omura, J. Antibiot., 2001, 54, 386.

28 T. Sunazuka, M. Handa, K. Nagai, T. Shirahata, Y. Harigaya, K. Otoguro, I. Kuwajima and S. Omura, Tetrahedron, 2004, 60, 7845.

29 W.-G. Kim, K.-M. Cho, C.-K. Lee and I.-D. Yoo, Tetrahedron Lett., 2002, 43, 3197.

30 W.-G. Kim, K.-M. Cho, C.-K. Lee and I.-D. Yoo, J. Antibiot., 2003, 56, 351 .

31 K.-M. Cho, W.-G. Kim, C.-K. Lee and I.-D. Yoo, J. Antibiot., 2003, 56, 344 .

32 I.-D. Yoo, K.-M. Cho, C.-K. Lee and W.-G. Kim, Bioorg. Med. Chem. Lett., 2005, 15, 353.

33 S. Omura, H. Tomoda, Y. K. Kim and H. Nishida, J. Antibiot., 1993, 46, 1168.

34 H. Tomoda, Y. K. Kim, H. Nishida, R. Masuma and S. Omura, J. Antibiot., 1994, 47, 148.

35 Y. K. Kim, H. Tomoda, H. Nishida, T. Sunazuka, R. Obata and S. Omura, J. Antibiot., 1994, 47, 154.

36 H. Tomoda, H. Nishida, Y. K. Kim, R. Obata, T. Sunazuka, S. Omura, J. Bordner, M. Guadliana, G. Dormer and A. B. Smith, J. Am. Chem. Soc., 1994, 116, 12097.

37 H. Tomoda, N. Tabata, D.-J. Yang, H. Takayanagi, H. Nishida and S. Omura, J. Antibiot., 1995, 48, 495.

38 H. Tomoda, N. Tabata, D.-J. Yang, I. Namatame, H. Tanaka and S. Omura, J. Antibiot., 1996, 49, 292.

39 H. Tomoda, N. Tabata, Y. Nakata, H. Nishida, T. Kaneko, R. Obata, T. Sunazuka and S. Omura, J. Org. Chem., 1996, 61, 882.

40 R. Ubillas, C. L. Barnes, H. Gracz, G. E. Rottinghaus and M. S. Tempesta, J. Chem. Soc., Chem. Commun., 1989, 1618.

41 Y. Zhang, C. Li, D. C. Swenson, J. B. Gloer, D. T. Wicklow and P. F. Dowd, Org. Lett., 2003, 5, 773.

42 C. Li, J. B. Gloer, D. T. Wicklow and P. F. Dowd, J. Nat. Prod., $2005,68,319$.

43 W. B. Turner, Fungal Metabolites, Academic Press, London, 1971, vol. 1 , pp. 74 and 213

44 B. B. Jarvis, J. Salemme and A. Moraes, Nat. Toxins, 1995, 3, 10.

45 R. Kaneto, K. Dobashi, I. Kojima, K. Sakai, N. Shibamoto, T. Yoshioka, H. Nishida, R. Okamoto, H. Akagawa and S. Mizuno, J. Antibiot., 1994, 47, 727. 
46 B. E. Roggo, P. Hug, S. Moss, A. Stampfli, H. P. Kriemler and H. H. Peter, J. Antibiot., 1996, 49, 374.

47 H. Kaise, M. Shinohara, W. Miyazaki, T. Izawas, Y. Nakano, M. Sugawara and K. Sugiura, J. Chem. Soc., Chem. Commun., 1979, 726.

48 B. B. Jarvis, Phytochemistry, 2003, 64, 53.

49 W. A. Ayer and S. Miao, Can. J. Chem., 1993, 71, 487.

50 K. Sakai, K. Watanabe, K. Masuda, M. Tsuji, K. Hasumi and A. Endo, J. Antibiot., 1995, 48, 447.

51 S. B. Singh, D. L. Zink, M. Williams, J. D. Polishook, M. Sanchez, K. C. Silverman and R. B. Lingham, Bioorg. Med. Chem. Lett., 1998, 8, 2071.

52 K. Minagawa, S. Kouzuki, J. Yoshimoto, Y. Kawamura, H. Tani, T. Iwata, Y. Terui, H. Nakai, S. Yagi, N. Hattori, T. Fujiwara and T. Kamigauchi, J. Antibiot., 2002, 55, 155.

53 K. Minagawa and S. Kouzuki, J. Antibiot., 2002, 55, 239.

54 K. Minagawa, S. Kouzuki, H. Tani, K. Ishii, T. Tanimoto, Y. Terui and T. Kamigauchi, J. Antibiot., 2002, 55, 239.

55 S. Stefaneli, F. Sponga, P. Ferrari, C. Sottani, E. Corti, C. Brunati and K. Islam, J. Antibiot., 1996, 49, 611.

56 S. F. Hinkley, J. C. Fettinger, K. Dudley and B. B. Jarvis, J. Antibiot., 1999, 52, 988.

57 X. Xu, F. S. de Guzman, J. B. Gloer and C. A. Shearer, J. Org. Chem., 1992, 57, 6700.

58 Y. Nozawa, M. Ito, K. Sugawara, K. Hanada and K. Mizoue, $J$. Antibiot., 1997, 50, 641.

59 H. Kawagish, M. Ando and T. Mizuno, Tetrahedron, 1990, 31, 373.

60 H. Kawagish, M. Ando, H. Sakamoto, S. Yoshida, F. Ojima, Y. Ishiguro, N. Ukai and S. Furukawa, Tetrahedron Lett., 1991, 32, 4561 .

61 H. Kawagish, M. Ando, K. Shinba, H. Sakamoto, S. Yoshida, F. Ojima, Y. Ishiguro, N. Ukai and S. Furukawa, Phytochemistry, 1992, 32, 175.

62 Y. Yaoita, K. Danbara and M. Kikuchi, Chem. Pharm. Bull., 2005, 53, 1202.

63 C. Shinohara, K. Hasumi, W. Hatsumi and A. Endo, J. Antibiot., 1996, 49, 961.

64 K. Hasumi, S. Ohyama, T. Kohyama, Y. Ohsaki, R. Takayasu and A. Endo, J. Antibiot., 1998, 51, 1059.

65 W. Hu, S. Ohyama and K. Hasumi, J. Antibiot., 2000, 53, 241.

66 W. Hu, Y. Kitano and K. Hasumi, J. Antibiot., 2003, 56, 832.

67 D. M. Roll, J. K. Manning and G. T. Carter, J. Antibiot., 1998, 51, 635.

68 A. M. Ainsworth, M. I. Chicarellirobinson, B. R. Copp, U. Fauth, P. J. Hylands, J. A. Holloway, M. Latif, G. B. Obeirne, N. Porter, D. V. Renno, M. Richards and N. Robinson, J. Antibiot., 1995, 48, 568 .

69 M. E. Raggatt, T. J. Simpson and M. I. Chicarelli-Robinson, Chem. Commun., 1997, 2245.

70 A. M. Bailey, R. J. Cox, K. Harley, C. M. Lazarus, T. J. Simpson and E. Skellam, Chem. Commun., 2007, 4053.

71 G. H. Harris, K. Hoogsteen, K. C. Silverman, S. L. Raghoobar, G. F. Bills, R. B. Lingham, J. L. Smith, H. W. Dougherty, C. Cascales and F. Pelaez, Tetrahedron, 1993, 49, 2139.

72 F. Mayerl, Q. Gao, S. Huang, S. E. Klohr, J. A. Matson, D. R. Gustavson, R. L. Berry, C. Fairchild and W. C. Rose, J. Antibiot., 1993, 46, 1082.

73 P. Cai, D. Smith, B. Cunningham, S. Brown-Shimer, B. Katz, C. Pearce, D. Venables and D. Houck, J. Nat. Prod., 1998, 61, 791.

74 S. Ayers, D. L. Zink, J. S. Powell, C. M. Brown, A. Grund, G. F. Bills, G. Platas, D. Thompson and S. B. Singh, J. Nat. Prod., 2008, 71, 457.

75 P. W. Clutterbuck, W. Percival, A. E. Oxford, H. Raistrick and G. Smith, Biochem. J., 1932, 26, 1441.

76 L. Canonica, W. Kroszczynski, B. M. Ranzi, B. Rindone, E. Santaniello and C. Scolastico, J. Chem. Soc., Perkin Trans. 1, 1972, 2639.

77 W. L. Muth and C. H. Nash III, Antimicrob. Agents Chemother., $1975,8,321$.

78 L. Colombo, C. Gennari, D. Potenza, C. Scolastico and F. Aragozzini, J. Chem. Soc., Chem. Commun., 1979, 1021.

79 L. Colombo, C. Gennari, D. Potenza, C. Scolastico, F. Aragozzini and R. Gualandris, J. Chem. Soc., Perkin Trans. 1, 1982, 365.

80 R. M. Horak, P. S. Steyn, R. Vleggaar and C. J. Rabie, J. Chem. Soc., Chem. Commun., 1981, 1265.
81 R. M. Horak, P. S. Steyn, R. Vleggaar and C. J. Rabie, J. Chem. Soc., Perkin Trans. 1, 1985, 345.

82 R. M. Horak, P. S. Steyn, R. Vleggaar and C. J. Rabie, J. Chem. Soc., Perkin Trans. 1, 1985, 363.

83 A. E. de Jesus, R. M. Horak, P. S. Steyn and R. Vleggaar, J. Chem. Soc., Chem. Commun., 1983, 716.

84 J. L. M. Dillen, R. M. Horak, V. J. Maharaj, S. F. Marais and R. Vleggaar, J. Chem. Soc., Chem. Commun., 1989, 393.

85 A. W. Dunn, R. A. W. Johnstone and B. Sklarz, J. Chem. Soc., Chem. Commun., 1976, 270a.

86 J. S. E. Holker and T. J. Simpson, J. Chem. Soc., Chem. Commun., 1978, 626.

87 T. J. Simpson, S. A. Ahmed, C. R. McIntyre, F. E. Scott and I. H. Sadler, Tetrahedron, 1997, 53, 4013.

88 T. J. Simpson, Tetrahedron Lett., 1981, 22, 3785.

89 A. W. Dunn, R. A. W. Johnstone, B. Sklarz, L. Lessinger and T. J. King, J. Chem. Soc., Chem. Commun., 1978, 533.

90 T. J. Simpson, J. Chem. Soc., Perkin Trans. 1, 1979, 2118.

91 C. R. McIntyre, F. E. Scott, T. J. Simpson, L. A. Trimble and J. C. Vederas, J. Chem. Soc., Chem. Commun., 1986, 501.

92 M. Cueto, J. B. MacMillan, P. R. Jensen and W. Fenical, Phytochemistry, 2006, 67, 1826.

93 T. J. Simpson and M. D. Walkinshaw, J. Chem. Soc., Chem. Commun., 1981, 914.

94 E. Okuyama and M. Yamazaki, Tetrahedron Lett., 1984, 25, 3233.

95 C. Rank, R. K. Phipps, P. Harris, P. Fristrup, T. O. Larsen and C. H. Gotfredsen, Org. Lett., 2008, 10, 401.

96 K. K. Chexal, J. P. Springer, J. Clardy, R. J. Cole, J. W. Kirksey, J. W. Dorner, H. G. Cutler and B. J. Strawter, J. Am. Chem. Soc., 1976, 98, 6748.

97 T. J. Simpson, D. J. Stenzel, A. J. Bartlett, E. O'Brien and J. S. E. Holker, J. Chem. Soc., Perkin Trans. 1, 1982, 2687.

98 T. J. Simpson, D. J. Stenzel, A. J. Bartlett, E. O'Brien and J. S. E. Holker, J. Chem. Soc., Perkin Trans. 1, 1982, 2687.

99 H. Hayashi, M. Mukaihara, S. Murao, M. Arai, A. Y. Lee and J. Clardy, Biosci., Biotechnol., Biochem., 1994, 58, 334.

100 R. M. G. Santos and E. Rodrigues-Fo, Phytochemistry, 2002, 61, 907.

101 R. M. G. Santos and E. Rodrigues-Fo, Z. Naturforsch., C, 2003, 58, 663.

102 (a) R. M. G. Santos, Ph.D. Thesis, Universidade Federal de São Carlos, Brasil, 2003; (b) T. P. Fill, G. K. Pereira, R. M. G. Santos and E. Rodrigues-Fo, Z. Naturforsch., B, 2007, 62, 1035.

103 R. M. G. Santos and E. Rodrigues-Fo, J. Braz. Chem. Soc., 2003, 14, 722.

104 R. Geris, E. Rodrigues-Fo, H. H. G. Silva and I. G. Silva, Chem. Biodiversity, 2008, 5, 341.

105 F. E. Scott, T. J. Simpson, L. A. Trimble and J. C. Vederas, J. Chem. Soc., Chem. Commun., 1986, 214.

106 S. A. Ahmed, F. E. Scott, D. J. Stenzel, T. J. Simpson, R. N. Moore, L. A. Trimble, K. Arai and J. C. Vederas, J. Chem. Soc., Perkin Trans. 1, 1989, 807.

107 E. Okuyama and M. Yamazaki, Tetrahedron Lett., 1983, 24, 3113.

108 D. B. Stierle, A. A. Stierle, J. D. Hobbs, J. Stokken and J. Clardy, Org. Lett., 2004, 6, 1049.

109 D. B. Stierle, A. A. Stierle and B. Patacini, J. Nat. Prod., 2007, 70, 1820.

110 M. Lida, T. Ooi, K. Kito, S. Yoshida, K. Kanoh, Y. Shizuri and T. Kusumi, Org. Lett., 2008, 10, 845.

111 K. Shiomi, R. Uchida, J. Inokoshi, H. Tanaka, Y. Iwai and S. Omura, Tetrahedron Lett., 1996, 37, 1265.

112 R. Uchida, K. Shiomi, J. Inokoshi, H. Tanaka, Y. Iwai and S. Omura, J. Antibiot., 1996, 49, 1278.

113 R. Uchida, K. Shiomi, J. Inokoshi, T. Sunazuka, H. Tanaka, Y. Iwai, H. Takayanagi and S. Omura, J. Antibiot., 1996, 49, 418.

114 S. Kosemura, K. Matsunaga, S. Yamamura, M. Kubota and S. Ohba, Tetrahedron Lett., 1991, 32, 3543.

115 S. Kosemura and S. Yamamura, Tetrahedron Lett., 1997, 38, 6221.

116 S. Kosemura, Tetrahedron Lett., 2002, 43, 1253.

117 S. Kosemura, K. Matsunaga and S. Yamamura, Chem. Lett., 1991, 1811.

118 S. Kosemura, Tetrahedron, 2003, 59, 5055.

119 S. Kosemura, S. Matsuo and S. Yamamura, Phytochemistry, 1996, 43, 1231 .

120 S. Kosemura, H. Miyata, K. Matsunaga and S. Yamamura, Tetrahedron Lett., 1992, 33, 3883. 
121 S. Kosemura, H. Miyata, S. Yamamura, K. Albone and T. J. Simpson, J. Chem. Soc., Perkin Trans. 1, 1994, 135.

122 J. P. Springer, J. W. Dorner, R. J. Cole and R. H. Cox, J. Org. Chem., 1979, 44, 4852.

123 C. R. McIntyre, D. Reed, I. H. Sadler and T. J. Simpson, J. Chem. Soc., Perkin Trans. 1, 1987, 1987.

124 C. R. McIntyre and T. J. Simpson, J. Chem. Soc., Chem. Commun., 1981,1043

125 C. R. McIntyre, F. E. Scott, T. J. Simpson, L. A. Trimble and J. C. Vederas, Tetrahedron, 1989, 45, 2307.

126 S. Komai, T. Hosoe, T. Itabashi, K. Nozawa, K. Okada, G. M. C. Takaki, T. Yaguchi, K. Takizawa, K. Fukushima and K. Kawai, Chem. Pharm. Bull., 2005, 53, 1114.

127 T. J. Simpson, Chem. Soc. Rev., 1987, 16, 123.

128 T. Sassa and H. Yoshikoshi, Agric. Biol. Chem., 1983, 47, 187.

129 T. Sassa and M. Nukina, Agric. Biol. Chem., 1984, 48, 1923.

130 T. Sassa, A. Ishizaki, M. Nukina, M. Ikeda and T. Sugiyama, Biosci. Biotechnol., Biochem., 1998, 62, 2260.

131 K. Ishibashi, J. Antibiot., 1962, 15, 161.

132 K. Hirai, S. Nozoe, K. Tsuda, Y. Litaka, K. Ishibashi and M. Shirasaka, Tetrahedron Lett., 1967, 8, 2177.

133 S. Nozoe, K. T. Suzuki and S. Okuda, Tetrahedron Lett., 1968, 9 , 3643.

134 S. Nozoe and K. Suzuki, Tetrahedron Lett., 1969, 10, 2457.

135 S. Nozoe and K. Suzuki, Tetrahedron, 1971, 27, 6063.

136 K. T. Suzuki and S. Nozoe, Bioorg. Chem., 1974, 3, 72.

137 J. Vrkoc, m. Budesinsky and L. Doleis, Phytochemistry, 1977, 16, 1409.

138 Y. Hirata, Biochem. Org. Chem., 1950, 7, 119.

139 L. Zechlin, M. Wolf, W. Steglich and T. Anke, Liebigs Ann. Chem., 1981, 2099.

140 T. Hashimoto, D. N. Quang, M. Nukada and Y. Asakawa, Heterocycles, 2005, 65, 2431.

141 N. Ishii, A. Takahashi, G. Kusano and S. Nozoe, Chem. Pharm. Bull., 1988, 36, 2918.

142 D. N. Quang, T. Hashimoto, Y. Arakawa, C. Kohchi, T. Nishizawa, G. H. Soma and Y. Asakawa, Bioorg. Med. Chem., 2006, 14, 164.

143 B. Koch and W. Steglich, Eur. J. Org. Chem., 2007, 1631.

144 X.-L. Yang, C. Qin, F. Wang, Z.-J. Song and J.-K. Liu, Chem. Biodiversity, 2008, 5, 484

145 D. Zhi-Hui, D. Ze-Jun and L. Ji-Kai, Helv. Chim. Acta, 2001, 84, 259.

146 M. Nukata, T. Hashimoto, I. Yamamoto, N. Iwasaki, M. Tanaka and Y. Asakawa, Phytochemistry, 2002, 59, 731.

147 M. Ikeda, H. Kanou and M. Nukina, Nogaku, 1989, 10, 849.

148 H. Misasa, Y. Matsui, H. Uehara, H. Tanaka, M. Ishihara and H. Shibata, Biosci. Biotechnol. Biochem., 1992, 56, 1660.

149 K. Sugiyama, T. Yoshida and H. Sakamoto, Jpn. Pat. JP 07101854, 1995.

150 V. Hellwig, R. Nopper, F. Mauler, J. Freitag, J.-K. Liu, Z. H. Ding and M. Stadler, Arch. Pharm. (Weinheim), 2003, 336, 119.

151 K. Dekermendjian, R. Shan, M. Nielsen, M. Stadler, O. Sterner and M. R. Witt, Eur. J. Med. Chem., 1997, 32, 351.

152 J. A. Ballantine, C. H. Hassall and G. Jones, J. Chem. Soc., 1965 , 4672.

153 J. A. Ballantine, C. H. Hassall, B. D. Jones and G. Jones, Phytochemistry, 1967, 6, 1157.

154 N. Cagnoli-Bellavita, P. Ceccherelli and T. F. M. Ribaldi, Phytochemistry, 1975, 14, 807.

155 S. Prapairat, I. Masahiko, K. Prasat, B. Uraiwan and T. Yodhathai, J. Antibiot., 2004, 57, 10.

156 R. K. Phipps, B. O. Petersen, K. B. Christensen, J. Ф. Duus, J. C. Frisvad and T. O. Larsen, Org. Lett., 2004, 6, 3441.

157 J. Beljak, O. Gribanovski-Sassu, B. M. Ranzi and A. Scala, Ann. Inst. Superiore Sanita, 1971, 7, 14.

158 L. Canonica, C. G. Casinovi, A. Fiecchi, C. Galeffi, G. B. MariniBettolo, A. Scala and A. M. Vaccaro Torracca, Gazz. Chim. Ital., 1976, 106, 147
159 K. Yoganathan, L. K. Yang, C. Rossant, Y. Huang, S. NG, M. S. Butler and A. D. Buss, J. Antibiot., 2004, 57, 59.

160 T. Fujioka, K. Yao, K. Hamano, T. Hosoya, T. Kagasaki, Y. Furukawa, H. Haruyma, S. Sato and T. Koga, J. Antibiot., 1996, 49, 409.

161 K. D. Barrow and W. S. Murphy, J. Chem. Soc., Perkin Trans. 1, $1972,2837$.

162 C. H. Lim, H. Miyagawa, M. Akamatsu, Y. Nakagawa and T. Ueno, Nippon Noyaku Gakkaishi, 1998, 23, 281.

163 P. M. Scott and J. W. Lawrence, Can. J. Microbiol., 1968, 14, 1015.

164 C. Huber, W. A. Court, J. P. Devlin, O. E. Edwards and P. M. Scott, Tetrahedron Lett., 1974, 15, 2545.

165 N. Koyama, T. Nagahiro, Y. Yamaguchi, R. Masuma, H. Tomoda and S. Omura, J. Antibiot., 2005, 58, 695.

166 L. Canonica, B. M. Ranzi, B. Rindoni, A. Scala and C. Scolastico, J. Chem. Soc., Chem. Commun., 1973, 213

167 L. Canonica, L. Colombo, C. Gennari, B. M. Ranzi and C. Scolastico, J. Chem. Soc., Chem. Commun., 1978, 679.

168 L. Canonica, M. G. Beretta, L. Colombo, C. Gennari, B. M. Ranzi and C. Scolastico, J. Chem. Soc., Perkin Trans. 1, 1980, 2686

169 R. D. Hutchison, P. S. Steyn and S. J. van Rensburg, Toxicol. Appl. Pharmacol., 1973, 24, 507.

170 A. E. de Jesus, W. E. Hull, P. S. Steyn, F. R. van Heerden and R. Vleggaar, J. Chem. Soc., Chem. Commun., 1982, 902.

171 R. M. Horak, V. J. Maharaj, S. F. Marais, F. R. van Heerden and R. Vleggaar, J. Chem. Soc., Chem. Comm., 1988, 23, 1562.

172 B. Sontag, N. Arnold, W. Steglich and T. Anke, J. Nat. Prod., 1999, 62, 1425 .

173 A. Mühlbauer, J. Beyer and W. Steglich, Tetrahedron Lett., 1998, 39, 5167.

174 W. Steglich, F. Esser and I. Pils, Z. Naturforsch., B, 1971, 26, 336.

175 R. L. Edwards and P. C. Beaumont, J. Chem. Soc., 1971, 14, 2582.

176 H. Besl, H. J. Hecht, P. Luger, V. Pasupathy and W. Steglich, Chem. Ber., 1975, 108, 3675.

177 T. Hayashi, A. Kanetoshi, M. Ikura and H. Shirahama, Chem. Pharm. Bull., 1989, 37, 1424

178 M. Lang, A. Mühlbauer, C. Gräf, J. Beyer, S. Lang-Fugmann, K. Polborn and W. Steglich, Eur. J. Org. Chem., 2008, 816.

179 B. Lieberman, R. Ellinger, W. Gunther, W. Ihn and H. Gallander, Phytochemistry, 1997, 46, 297.

180 R. P. Nussbaum, W. Gunther, S. Heinze and B. Liebermann, Phytochemistry, 1999, 52, 593.

181 B. Liebermann, R.-P. Nussbaum and W. Gunther, Phytochemistry, $2000, \mathbf{5 5}, 987$.

182 B. Liebermann, R.-P. Nussbaum, W. Gunther and J. M. Teuscher, Phytochemistry, 2001, 56, 551.

183 R. T. Gallager, T. McCabe, K. Hirotsu and J. Clardy, Tetrahedron Lett., 1980, 21, 243.

184 D. T. Wicklow, P. F. Dowd, M. R. TePaske and J. B. Gloer, Trans. Brit. Mycol. Soc., 1988, 91, 433.

185 J. B. Gloer, M. R. TePaske and J. Sima, J. Org. Chem., 1988, 53, 5457

186 M. R. TePaske and J. B. Gloer, J. Org. Chem., 1990, 55, 5299.

187 J. B. Gloer, B. L. Rinderknecht, D. T. Wicklow and P. F. Dowd, J. Org. Chem., 1989, 54, 2530.

188 G. M. Staub, J. B. Gloer, D. T. Wicklow and P. F. Dowd, J. Am. Chem. Soc., 1992, 114, 1015.

189 M. R. TePaske and J. B. Gloer, Tetrahedron, 1989, 45, 4961.

190 M. R. TePaske, J. B. Gloer and D. T. Wicklow, J. Org. Chem., 1989, 54, 4743 .

191 J. A. Laakso and J. B. Gloer, J. Org. Chem., 1992, 57, 138.

192 C. Li, J. B. Gloer, D. T. Wicklow and P. F. Dowd, Org. Lett., 2002, 4, 3095.

193 C. Li, J. B. Gloer and D. T. Wicklow, J. Nat. Prod., 2003, 66, 1232.

194 M. R. TePaske, J. B. Gloer, D. T. Wicklow and P. F. Dowd, J. Org. Chem., 1989, 54, 4743.

195 B. Sontag, M. Ruth, P. Spiteller, N. Arnold, W. Steglich, M. Reichert and G. Bringmann, Eur. J. Org. Chem., 2006, 1023. 